UNIVERSIDADE DE SÃO PAULO

FACULDADE DE FILOSOFIA, LETRAS E CIÊNCIAS HUMANAS

DEPARTAMENTO DE HISTÓRIA

PROGRAMA DE PÓS-GRADUAÇÃO EM HISTÓRIA SOCIAL

\title{
A REPÚBLICA E A ESPADA: A PRIMEIRA DÉCADA REPUBLICANA E O FLORIANISMO
}

Guillaume Azevedo Marques de Saes

Dissertação apresentada ao Programa de Pós-Graduação em História Social, do Departamento de História da Faculdade de Filosofia, Letras e Ciências Humanas da Universidade de São Paulo, para obtenção do título de Mestre em História.

Orientador: Prof. Dr. Ulysses Telles Guariba Netto

São Paulo

2005 
UNIVERSIDADE DE SÃO PAULO

FACULDADE DE FILOSOFIA, LETRAS E CIÊNCIAS HUMANAS DEPARTAMENTO DE HISTÓRIA

PROGRAMA DE HISTÓRIA SOCIAL

\section{A REPÚBLICA E A ESPADA: A PRIMEIRA DÉCADA REPUBLICANA E O FLORIANISMO}

Guillaume Azevedo Marques de Saes

São Paulo 2005 
Dedico esta dissertação a meus pais Décio e Michèle e a meu irmão Laurent. 


\section{AGRADECIMENTOS}

Antes de mais nada, eu gostaria de agradecer ao meu orientador, Prof. Dr. Ulysses Telles Guariba Netto, sem quem nada disto teria sido possível, e à banca de qualificação, composta pelos Profs. Drs. Fernando Antonio Novais e Eduardo Kugelmas, pelas valiosas sugestões que contribuíram para melhorar o conteúdo do trabalho.

Gostaria de agradecer aos Profs. Drs. Augustin Wernet, Brasilio João Sallum Júnior, Cecília Helena Lorenzini de Salles Oliveira e Emir Simão Sader, docentes responsáveis pelas disciplinas que cursei em 2002-2003, e aos Profs. Drs. Oliveiros S. Ferreira e Suely Robles Reis de Queiroz, que gentilmente me aceitaram como aluno ouvinte em seus respectivos cursos no ano de 2005.

Gostaria de agradecer aos Profs. Drs. João Ricardo de Castro Caldeira e Fernando Tadeu de Miranda Borges pela oportunidade de participar de seus respectivos projetos acadêmicos, e aos Profs. José Batista de Carvalho e Renato Alencar Dotta pela oportunidade de participar de seu projeto de documentação histórica.

Gostaria de agradecer ao Prof. Dr. Modesto Florenzano, que me orientou no período da Iniciação Científica em 1999-2000 e me introduziu no mundo da pesquisa histórica.

Gostaria de agradecer a meus pais Décio e Michèle e a meu irmão Laurent pelo apoio moral assim como pela ajuda na correção dos originais.

Gostaria de agradecer a meus colegas Marcelo Augusto Moraes Gomes, Antônio Éuler Lopes Camargo, Eliane Maria Brito e Walaci Henrique Machado pelo agradável convívio neste período de pós-graduação e pela importante troca de material e informações.

Finalmente, gostaria de agradecer aos funcionários das bibliotecas da Faculdade de Filosofia, Letras e Ciências Humanas, do Instituto de Estudos Brasileiros e do Museu Paulista, aos funcionários da Biblioteca Mário de Andrade, cujo acervo bibliográfico foi muito útil para minha pesquisa, assim como aos 
funcionários do Serviço de Pós-Graduação da Faculdade de Filosofia, Letras e Ciências Humanas e do Departamento de História da Universidade de São Paulo. 


\section{SUMÁRIO}

Resumo pág. 7

Abstract pág. 7

Índice pág. 8 Introdução pág. 10

Capítulo I - As diferentes dimensões do Florianismo: esboço de uma caracterização pág. 18 Capítulo II - O Deodorismo: papel político e significado histórico pág. 54 Capítulo III - O Florianismo e a luta pela hegemonia política (1891-1897)pág. 78 Conclusão pág. 130 Bibliografia pág. 134 


\title{
RESUMO
}

Esta dissertação aborda o tema do Florianismo, isto é o fenômeno políticomilitar brasileiro que girou em torno da figura do Marechal Floriano Peixoto. Este fenômeno durou de 1891 a 1897, e abarcou o governo presidencial de Floriano (1891-1894) e a ação política contemporânea e posterior de seus seguidores. Nosso objetivo é analisar o papel do Florianismo na implantação da ordem republicana que vigorou até 1930 , ordem dominada pelos republicanos paulistas e seus aliados.

\begin{abstract}
The present dissertation tackles the subject of Florianism, the brazilian political-military phenomenom which grew around the figure of Marshall Floriano Peixoto. This phenomenon took place between 1891 and 1897, and comprised Floriano's presidential government (1891-1894) as well as the contemporary and subsequent political action of his followers. Our objective is to analyse the role of Florianism in the establishment of the republican order which lasted until 1930, an order ruled by São Paulo's republicans and their allies.
\end{abstract}

palavras-chave: florianismo, fenômeno, política, militares, república

key words: florianism, phenomenon, politics, military, republic 


\section{ÍNDICE}

I. Introdução pág. 10

II. Capítulo I - As diferentes dimensões do Florianismo: esboço de uma caracterização pág. 18 III. Capítulo II - 0 Deodorismo: papel político e

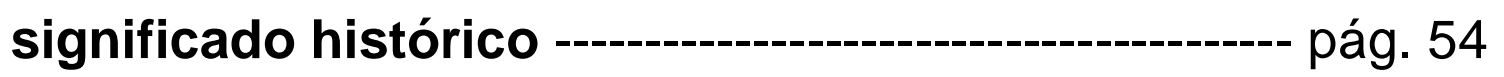
IV. Capítulo III - O Florianismo e a luta pela hegemonia política (1891-1897)------------------------------------------- pág. 78

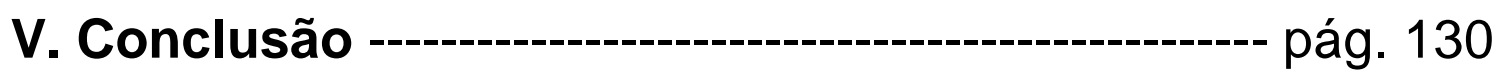

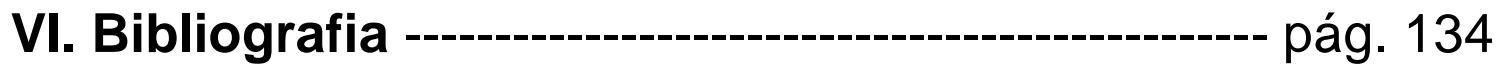


Acredito que há certos homens que nascem para servir de meio à marcha do gênero humano.

Luís-Napoleão Bonaparte (1845). ${ }^{1}$

${ }^{1}$ Tirado do livro de Francis Choisel, Bonapartisme et Gaullisme (Paris: Editions Albatros, 1987), p. 16, e traduzido do francês por nós. 


\section{INTRODUÇÃO}

Euclides da Cunha, em seu monumental clássico Os Sertões ${ }^{2}$, nos dá, em passagem da p. 389, uma boa idéia do fervor ideológico provocado pela figura do Marechal Floriano Peixoto em seus seguidores, ao descrever o entusiasmo florianista dos soldados que combatiam os jagunços de Antônio Conselheiro em Canudos: A luta pela República, e contra os seus imaginários inimigos, era uma cruzada. Os modernos templários, se não envergavam a armadura debaixo do hábito e não levavam a cruz aberta nos copos da espada, combatiam com a mesma fé inamolgável. Os que daquele modo se abatiam à entrada de Canudos tinham todos, sem excetuar um único, colgada ao peito esquerdo, em medalhas de bronze, a efígie do marechal Floriano Peixoto, e, morrendo, saudavam a sua memória - com o mesmo entusiasmo delirante, com a mesma dedicação incoercível e com a mesma aberração fanática, com que os jagunços bradavam pelo Bom Jesus misericordioso e milagreiro... Esta descrição, não desprovida de exageração literária, é, no entanto, importante por abordar a dimensão mítica, e até mesmo religiosa, do Florianismo. Encontramos aqui um endeusamento do líder nacionalista e militar, assim como um culto heróico da morte: Floriano, embora já morto, continuava a inspirar as tropas combatentes, prontas a morrer em seu nome. Euclides, mesmo assumindo postura bastante crítica em relação ao Florianismo, não deixa de revelar, ao contrário da crítica aberta e até mesmo desrespeitosa de um Lima Barreto ou de um Joaquim Nabuco ${ }^{3}$, uma posição dúbia entre a admiração pelo Marechal de Ferro e o desprezo por seus seguidores ${ }^{4}$.

\footnotetext{
${ }^{2}$ Para todos os títulos e autores citados ao longo da dissertação, ver Bibliografia.

${ }^{3}$ Lima Barreto, em seu romance abertamente anti-florianista Triste Fim de Policarpo Quaresma, apresenta, na Terceira Parte, o Marechal como indivíduo cínico, cruel e preguiçoso. Já Joaquim Nabuco, opositor convicto de Floriano, denigre este último, em seu livro panfletário A Intervenção Estrangeira Durante a Revolta de 1893 (p. 150), ao afirmar que raciocinava deficientemente em decorrência de sua decadência física, o que não deixa de ser para nós uma falta de respeito por um homem que teve a saúde desgastada nos insalubres campos de batalha do Paraguai.

${ }^{4} \mathrm{Na}$ p. 249 do mesmo Os Sertões, Euclides descreve de forma pejorativa, ao se basear nas idéias do italiano Scipio Sighele, estudioso dos crimes coletivos, o Florianismo enquanto movimento político conduzido por agitadores de massa de baixa índole moral: Surgiram, então, na tribuna, na
} 
Olímpio de Souza Andrade, em sua excelente introdução ao livro Contrastes e Confrontos, de autoria do mesmo Euclides da Cunha e onde encontramos duas crônicas dedicadas a Floriano, explica, na p. 16, o fascínio exercido por este no grande escritor brasileiro: Na série brasileira de Contrastes e Confrontos um tema existe que foi quase obsessão em Euclides da Cunha (...). Referimo-nos ao assunto "Floriano Peixoto", objeto de número enorme de estudos isolados ou em Histórias do Brasil, mas que só na pena de Euclides se colocou como um enigma em páginas de extraordinário poder de comunicação, "desenhando" o físico, os gestos, a psicologia difícil de um homem nada comunicativo, cioso dos seus segredos, dos mistérios que escondia nas palavras, que às vezes parecia revelar nas atitudes, de antemão baralhadas pelo que dissera antes, mais baralhadas pelo que passava a dizer depois (...). Euclides, um escancarado em suas convicções, teria sido atraído pelo seu contrário ao aproximar-se, como escritor, dessa figura fechada, dúbia, para defini-la magistralmente, a ponto de suas páginas sobre o assunto ficarem até hoje como a única perspectiva duradoura já traçada sobre aquela personificação da dúvida e do recuo, da confiança desconfiada... Fora o fato de Euclides ter se envolvido pessoalmente nas lutas políticas do período florianista, já que o General Sólon Ribeiro, seu sogro, participara das conspirações contra o Marechal de Ferro, o que o levaria a ser preso pelo governo, e, depois, o próprio Euclides tomara parte, enquanto oficial-engenheiro do Exército, na defesa do Governo Floriano contra os revoltosos da Armada $^{5}$, podemos notar todavia que o autor tem consciência da importância do papel de Floriano e do Florianismo para a evolução histórica do Brasil. Como afirma José Maria Bello (p. 82), a respeito do Marechal de Ferro, nenhuma figura da história brasileira tem sido mais discutida do que a sua. Inspirou aos seus coevos ardentes fanatismos e tremendos ódios; isto é, por mais

\footnotetext{
imprensa e nas ruas - sobretudo nas ruas - individualidades que nas situações normais tombariam à pressão do próprio ridículo. Sem ideais, sem orientação nobilitadora, peados num estreito círculo de idéias, em que entusiasmo suspeito pela República se aliava a nativismo extemporâneo e à cópia grosseira de um jacobinismo pouco lisongeiro à história - aqueles agitadores começaram a viver da exploração pecaminosa de um cadáver. O túmulo do marechal Floriano Peixoto foi transmudado na arca da aliança da rebeldia impenitente e o nome do grande homem fez-se a palavra de ordem da desordem.

${ }^{5}$ Ver o Guia de Leitura escrito por Roberto Ventura para a edição de Os Sertões que utilizamos neste trabalho.
} 
que personagens como Deodoro e Benjamin Constant tenham tido papel fundamental nos primórdios do período republicano, Floriano foi o que provocou maior impacto: como observa Jehovah Motta (pp. 150-151), Deodoro e Benjamin Constant jamais alcançaram o plano da política e, rápido, passaram. Somente Floriano possuía as armas com que se terçam as lutas do poder, ele que tinha do homem e da vida uma visão realística e estranhamente lúcida. Isto seria impossível, a nosso ver, se o Marechal de Ferro não tivesse função de relevo na construção da ordem política posterior ao seu governo, se ele não tivesse deixado uma herança e uma contribuição importante para a consolidação do status quo que duraria até a derrubada da República Velha. É este papel que nos propomos a estudar. Como pode parecer contraditório, à primeira vista, que um fenômeno político-militar de cunho nacionalista, autoritário e progressista seja o responsável pela implantação de uma república civil, liberal e representante dos grupos agroexportadores de São Paulo, acreditamos que este aspecto merece um estudo aprofundado.

Pretendemos, através da pesquisa intitulada A República e a Espada: a primeira década republicana e o Florianismo, estudar o lugar do fenômeno político-militar nacionalista e republicano que girou em torno da figura do Marechal Floriano Peixoto na construção da ordem política vigente na Primeira República brasileira, que viria a ser dominada pelo Partido Republicano Paulista e os seus aliados até 1930. Utilizamos a expressão fenômeno, em vez de movimento, ou sistema, por ser ela mais abrangente, englobando o governo do Marechal Floriano Peixoto (1891-1894) e as correntes que o apoiavam, que continuarão na luta em seu nome até o ano de 1897. No entanto, pretendemos acrescentar, à expressão fenômeno político, a palavra militar, porque acreditamos ser 0 Florianismo a expressão política de uma ala do Exército, ala de cunho nacionalista e republicano que vai ter o apoio de alguns setores médios urbanos e de camadas sub-proletárias do Rio de Janeiro.

Para melhor introduzirmos a problemática, façamos uma breve recapitulação histórica. O Florianismo nasce do fracasso do Deodorismo, a quem 
estava incumbido o papel histórico que aquele virá a cumprir posteriormente. Melhor dizendo, o dia 15 de novembro de 1889 significa a derrubada da já agonizante ordem imperial, e com o Governo Provisório (1889-1891) sobe ao poder uma coalizão republicana representada pelo Marechal Deodoro da Fonseca, líder da revolução. A função histórica de um governo sob controle militar naquele momento histórico seria, no nosso entender, a de desalojar a elite imperial do poder, nem que fosse pela força, e reformar o Estado para que uma nova elite pudesse em seguida assumir o controle político do país. No entanto, Deodoro da Fonseca, por causa de seu conservadorismo e sua falta de habilidade política, não estará à altura do papel histórico que Ihe cabia: seus constantes confrontos com importantes grupos civis e militares o farão sair do poder de forma turbulenta. A ala nacionalista e progressista do Exército, representada por Floriano Peixoto, será a alternativa para a consolidação da nova ordem frente às ameaças vindas de grupos remanescentes da antiga elite imperial, que procuram retomar o poder mesmo que sob o modelo republicano. O autoritarismo florianista fará o expurgo necessário para a posterior ascensão do Partido Republicano Paulista, representante da ascendente e poderosa elite exportadora de café, ao poder. Por outro lado, o Florianismo, possuindo um projeto de desenvolvimento antagônico a este partido, após conseguir, pela força, sufocar as revoltas que ameaçavam a futura ascensão paulista, tornar-se-á dispensável e será por sua vez desalojado. $O$ período presidencial de Prudente de Moraes será caracterizado, em sua maior parte, pela luta do PRP contra os florianistas já reduzidos a movimento de oposição e desejosos de retornar ao poder: as revoltas dos alunos militares (1895 e 1897), a agressiva propaganda jacobina e o empenho de militares florianistas como Moreira César e Artur Oscar em esmagar o arraial monarquista de Canudos são sinais da tensão política do período pós-Floriano. No entanto, sem possuir base de apoio sólida após o rompimento com São Paulo, o Florianismo desaparecerá, tendo como duplo golpe de misericórdia o mau desempenho do Exército na guerra contra os jagunços de Antônio Conselheiro e o atentado frustrado a Prudente de Moraes em 5 de novembro de 1897. 
Portanto, partindo do pressuposto de que o Florianismo é um fenômeno político-militar de cunho nacionalista, autoritário e progressista, fenômeno que envolve tanto o governo do Marechal Floriano Peixoto (1891-1894) quanto o movimento que gira em torno de sua figura e que não durará além de 1897, fundamentaremos nosso trabalho em duas hipóteses, que são as seguintes: 1) 0 Florianismo, em seu período no poder presidencial, ao receber o apoio político e material de São Paulo, terá a função de preparar a ascensão do Partido Republicano Paulista a nível federal, na medida em que seu governo autoritário irá, pela força, desalojar do poder os remanescentes da antiga elite imperial; 2) 0 Florianismo, possuindo um projeto político, econômico e social diferente daquele defendido pelo Partido Republicano Paulista, tendo concluído sua missão histórica, passará, com a ascensão de Prudente de Moraes à Presidência da República, para a oposição; a ação política dos florianistas, embora virulenta, se mostrou destituída de apoio sólido após o rompimento com São Paulo, e o movimento desapareceu para triunfo da república civil sob controle paulista e, posteriormente, também mineiro.

O tema do Florianismo tem sido pouco trabalhado de forma sistemática na historiografia brasileira. Primeiramente, faltou ao Marechal um biógrafo à altura de um R. Magalhães Júnior, autor do valioso Deodoro, a Espada contra o Império, obra de dois volumes onde a vida do personagem em questão é inserida, de forma pertinente, imparcial, e às vezes até crítica, dentro do contexto político de sua época. A vida de Floriano, ao contrário, foi objeto de uma série de estudos de cunho apologético, como os de Cyro Silva, Salm de Miranda, Sylvio Peixoto, Joaquim Laranjeira, Artur Vieira Peixoto e Francolino Cameu', estudos sem grande valor historiográfico, a não ser por dados, tirados de arquivos, sobre a carreira militar do biografado. No entanto, o personagem de Floriano e o fenômeno do Florianismo aparecem em diversos trabalhos importantes sobre o contexto político do início da República, mesmo não sendo, na maioria das vezes, o foco

\footnotetext{
${ }^{6}$ Não podemos esquecer de citar, como obra apologética, a série Floriano: Memórias e Documentos, obra de cinco volumes publicada pelo Ministério da Educação em 1939, ano da comemoração dos cem anos de nascimento do Marechal. Seria interessante observar que esta publicação acontecia em pleno Estado Novo, quando o nacionalismo militar estava em alta.
} 
central desses trabalhos. No que diz respeito aos estudos específicos sobre o Florianismo, podemos citar três: o ensaio clássico $\mathbf{O}$ significado do Florianismo, incluído no livro História Nova do Brasil Vol. IV, um dos raros trabalhos interpretativos sobre o governo de Floriano Peixoto; o livro, também clássico, Os Radicais da República. Jacobinismo: ideologia e ação, 1893-1897, de Suely Robles Reis de Queiroz, que aborda o tema dos jacobinos brasileiros (e sobretudo os cariocas), ala mais radical do Florianismo; e o mais recente O Progresso da Ordem: o florianismo e a construção da República, de Lincoln de Abreu Penna, que analisa de forma interessante o Florianismo enquanto movimento político de cunho bonapartista dentro do qual estão inseridas diferentes tendências e representações ${ }^{7}$. Muito contribuem para o estudo do Florianismo os trabalhos dos brasilianistas norte-americanos John Schulz e June Hahner a respeito do envolvimento dos militares na política brasileira: o primeiro, em seu O Exército na Política: Origens da Intervenção Militar, 1850-1894, analisa a participação da oficialidade do Exército na vida política brasileira na segunda metade do século XIX, e a segunda, em seu Relações entre civis e militares no Brasil, 18891898, analisa a participação militar na vida política da turbulenta primeira década republicana, sendo que em ambos os livros o Florianismo assume papel de destaque. Os manuais clássicos sobre a história republicana, como os de José Maria Bello, Edgard Carone, Hélio Silva e Leôncio Basbaum, por descreverem a evolução factual do período que nos propomos a estudar, serão utilizados em nosso trabalho. Diversos outros autores, que trabalham temas específicos do período, como a Revolta da Armada, a Revolução Federalista, a Guerra de Canudos, o Partido Republicano Paulista e o Castilhismo serão devidamente citados ao longo da dissertação.

Embora tentados, a princípio, a trabalhar com fontes primárias, em especial a documentação situada no Arquivo Nacional e no Arquivo Histórico do Exército, ambos no Rio de Janeiro, optamos por um estudo baseado exclusivamente em

\footnotetext{
${ }^{7}$ Embora tentados a fazer, nesta dissertação de mestrado, a analogia do Florianismo com o Bonapartismo, baseando-nos não somente nos clássicos de Karl Marx que constam na bibliografia de nosso trabalho, mas também em estudos recentes e especializados sobre o fenômeno bonapartista, como os de Frédéric Bluche e de Francis Choisel entre outros, acreditamos que o assunto, por demais complexo, mereceria um estudo à parte.
} 
pesquisa bibliográfica. Mesmo que, como dissemos, o Florianismo tenha sido pouco trabalhado de forma sistemática na historiografia brasileira, esta oferece de sobra material para uma análise interpretativa do fenômeno, devido à aparição deste em importantes estudos sobre a Primeira República e o papel político das Forças Armadas. A nosso ver, a análise de fontes primárias teria mais cabimento após uma análise interpretativa mais sistemática do tema do Florianismo e de seu papel histórico, para que posteriormente um trabalho com essas fontes primárias pudesse se assentar em bases mais sólidas.

Nossa dissertação será dividida em três capítulos: o primeiro, intitulado As diferentes dimensões do Florianismo: esboço de uma caracterização, procurará definir o Florianismo enquanto fenômeno político-militar, fazendo primeiramente uma síntese biográfica do Marechal Floriano Peixoto, levantando em seguida os principais aspectos de seu governo presidencial e de seus seguidores; o segundo capítulo, intitulado O Deodorismo: papel político e significado histórico, abordará o período deodorista (1889-1891), sem cuja compreensão não se poderá, de forma alguma, entender o papel da política florianista; e o terceiro, de nome O Florianismo e a luta pela hegemonia política (1891-1897) estudará propriamente o período onde estão inseridos o Governo Floriano e a maior parte do Governo Prudente, e que vai se caracterizar pelas lutas políticas envolvendo o Florianismo, tanto no poder quanto na oposição; é este último capítulo o mais importante para o tratamento do tema central de nosso trabalho: o papel do Florianismo na construção da ordem política da República Velha.

Antes de concluirmos esta parte introdutória, cabe-nos fazer duas observações: 1) não nos filiamos a nenhuma escola teórica específica, e portanto procuraremos utilizar diversos autores, independentemente de sua linha teórica e de sua posição política, importando apenas aqui sua utilidade para a construção de um esquema teórico operacional ; 2) não procuraremos fazer, ao longo do trabalho, uma exaustiva descrição factual do período em questão, o que seria 
mera repetição dos manuais de história republicana do Brasil, e sim procuraremos utilizar os fatos no sentido de ilustrar nosso esquema interpretativo.

Como salienta Wilma Peres Costa (p. 16), é preciso deixar claro que a República não foi só uma transformação pacífica. Bem ao contrário. Para além da surpresa provocada pelo golpe de Estado de 15 de novembro, seguiu-se uma década de conflitos e violências de toda ordem, na qual se sucederam as dissensões militares, os conflitos intra-oligárquicos, os motins populares, a guerra civil, o atentado contra a vida de um presidente da República. Procuraremos mostrar que o Florianismo foi o golpe de força exigido pelas circunstâncias atípicas e violentas de seu tempo. 


\section{CAPÍTULO I: AS DIFERENTES DIMENSÕES DO FLORIANISMO: ESBOCO DE UMA CARACTERIZACÂO}

\section{A) Floriano Peixoto: o militar e o político'.}

\section{1) Origens.}

Floriano Vieira Peixoto nasceu a 30 de abril de 1839 no engenho Riacho Grande, de propriedade de seu pai, situado na região de Ipioca, litoral da então Província das Alagoas. Sendo o quinto filho, de uma prole de dez, de um proprietário empobrecido, Floriano é entregue aos cuidados de seu tio (e futuro sogro), o Coronel José Vieira de Araújo Peixoto, senhor de engenho de maiores recursos pecuniários e homem de destacada posição econômica e política na região ${ }^{2}$; ele chefiará em 1844 uma revolução contra o Presidente da Província, Bernardo de Souza Franco, forçando-o a fugir da capital ${ }^{3}$.

Etnicamente, Floriano se encaixa dentro do perfil do caboclo ${ }^{4}$, o que the daria um caráter genuinamente brasileiro frente ao "cosmopolitismo" da elite política nacional: Se para a maior parte das elites brasileiras, Floriano pôde ser uma expressão das forças mais bárbaras da alma do País, uma espécie de

\footnotetext{
${ }^{1}$ Sendo o nosso objetivo aqui o de traçar um perfil político e profissional do Marechal Floriano Peixoto, deixaremos de lado a análise psicológica do personagem, análise presente por exemplo nos clássicos História da República, de José Maria Bello, e Contrastes e Confrontos, de Euclides da Cunha, na medida em que preferimos reservá-la para um estudo mais detalhado sobre o Florianismo que aprofunde os aspectos sociológicos deste.

${ }^{2}$ Para todas essas informações, ver Salm de Miranda (p. 22) e Cyro Silva (p. 15).

${ }^{3}$ Esta revolta está inserida dentro do contexto da sangrenta disputa que dividia a política alagoana em dois partidos, os lisos (Partido Liberal) e os cabeludos (Partido Conservador); o Coronel Vieira Peixoto pertencia a este último grupo (ver nota da p. 72 do ensaio de Lincoln de Abreu Penna, Floriano e o Rio, incluído em seu livro Por que somos Florianistas?, e Salm de Miranda, p. 22).

${ }^{4}$ Segundo Salm de Miranda (p. 23), pelo tipo físico de Floriano evidencia-se claramente a existência de sangue indígena nas suas veias: pele morena bronzeada, cabelos pretos, lisos e corridos, olhos pardos, do tipo característico conhecido entre nós por "indiáticos"; o rosto quase glabro, onde apenas se notava "uma promessa de bigode", diminuta pêra entre o lábio e o queixo e umas "suíças" sumárias. Além disto, o seu temperamento pouco vibrátil, calmo, imperturbável dentro do perigo ou diante dos mais graves acontecimentos, "calmo como um tupi" disse dele Dionísio Cerqueira que foi seu amigo, todos estes fatos físicos, morais e psíquicos são indícios que nos afirmam sua ascendência cabocla.
} 
retardado na crosta da civilização litorânea, ou do que em outro plano psicológico e outras condições sociais, seria, por exemplo, para os norte-americanos, ainda educados no clima de Washington, de Jefferson e de Hamilton, a presidência do rude frontierman Jackson, para a enorme massa dos seus contemporâneos encarnava justamente o que havia de mais profundo, mais sincero e mais telúrico na nacionalidade. Quebrado o verniz da sua vida, mal adaptado a modelos exóticos, o Brasil primitivo encontraria perfeita correspondência com a fria, astuciosa e indomável psique do seu herói caboclo. Assim, pôde ser por muito tempo, e um pouco ainda hoje, um símbolo da nação autêntica dos sertões imensos e brutos contra a nação artificial das cidades, que o Império alimentara e os bacharéis e jornalistas do Governo Provisório supunham intangível... ${ }^{5}$. A figura nacionalista de Floriano viria a contrastar com a figura cosmopolita e aristocrática de um Saldanha da Gama, assim como da oficialidade da Marinha em geral, cosmopolitismo e postura aristocrática que são muito bem lembrados por José Murilo de Carvalho ${ }^{6}$ : o estilo aristocrático do oficial da marinha personificou-se no fim do Império e início da República na figura de Saldanha da Gama, que tanto brilhava na Academia Naval, de que era diretor, como nos teatros e salões do Brasil e do exterior. O pequeno número de oficiais desta arma e suas constantes viagens ao exterior que exigiam maior cosmopolitismo, favoreciam e encorajavam a manutenção deste padrão superior de recrutamento.

\section{2) No Exército.}

Tendo feito seus estudos primários em Maceió, Floriano é trazido aos dezesseis anos de idade para a Corte, onde faz os preparatórios. Optando pela carreira militar, em $1^{\circ}$ de maio de 1857 assenta praça como soldado-voluntário no $1^{\circ}$ Batalhão de Artilharia a Pé, que guarnecia a Fortaleza de Santa Cruz ${ }^{7}$. Cursa a

\footnotetext{
${ }^{5}$ José Maria Bello, p. 83.

${ }^{6}$ As Forças Armadas na Primeira República: o Poder Desestabilizador, p. 189.

${ }^{7}$ Salm de Miranda, pp. 24-25.
} 
Escola Central e a Escola Militar, as escolas que o Exército possuía na Corte ${ }^{8}$. Em fins de 1863 , Floriano é promovido a $1^{\circ}$ Tenente de Artilharia ${ }^{9}$.

\section{3) Na Guerra do Paraguai (1865-1870).}

Em fevereiro de 1865, quando o Paraguai já começara sua ofensiva contra o Brasil, Floriano estava servindo na guarnição de Uruguaiana, no Rio Grande do Sul. Sua primeira função no conflito consistirá em exercer as funções de instrutor de voluntários e milicianos no manejo das armas Minié, recém-introduzidas no Exército imperial, e de encarregado da construção das fortificações nesta mesma cidade $^{10}$.

Seu batismo de fogo ocorre nos dias 31 de julho, e $1^{\circ}$ e 2 de agosto de 1865, no contexto da invasão do Rio Grande do Sul pelas forças paraguaias do Coronel Estigarríbia. Floriano é encarregado pelo general honorário David Canabarro, veterano da Revolução Farroupilha e Comandante do Setor, de comandar uma esquadrilha improvisada composta de um pequeno rebocador fluvial e de dois lanchões no rio Uruguai, no intuito de cortar a ligação entre as duas colunas invasoras que desciam em direção ao Sul (uma ao longo da margem brasileira e a outra ao longo da margem Argentina do rio) para se juntarem às tropas do General Robles, que descia pelo território argentino, e atacarem as tropas imperiais em território uruguaio. A ligação entre as duas colunas sendo feita por numerosa flotilha de canoas armadas com vinte soldados cada uma, a esquadrilha de Floriano, ao metralhar sem trégua as canoas, afundando muitas delas, consegue cumprir sua função. Isto mais a participação importante da mesma esquadrilha no combate de Itaí, onde o general uruguaio Venâncio Flores

\footnotetext{
${ }^{8}$ A Escola Central tinha como função o ensino das ciências e técnicas da engenharia militar e também civil (daí a presença de alunos civis na instituição), enquanto que a Escola Militar ensinava a técnica profissional militar, isto é o manejo das armas, a vivência das marchas, a administração dos Corpos. O desdobramento da antiga Escola Militar em duas realizou-se em 1855 e só duraria até 1874, quando a Escola Central foi transformada em Escola Politécnica, dedicando-se exclusivamente aos problemas da engenharia civil, o Exército ficando apenas com a Escola Militar, que passava a se encarregar também do ensino da engenharia militar (para maiores detalhes sobre este período do ensino militar, ver Jehovah Motta, pp. 125-173).

${ }^{9}$ Salm de Miranda, p. 26.

${ }^{10}$ Cyro Silva, p. 17.
} 
derrota a coluna paraguaia do Major Pedro Duarte, valem a Floriano a promoção a Capitão e o título de Cavaleiro da Ordem de Cristo ${ }^{11}$.

Ao longo da guerra, já em território paraguaio, Floriano tomará parte em diversos combates como Estero Bellaco, Tuiuti, Laurelles, Timbó, Potrero Obella, Itororó e Avaí. Entrará em Assunção, em 6 de janeiro de 1869, a frente do $9^{\circ}$ Batalhão de Infantaria, após ter combatido em Lomas Valentinas e Angustura, e participará da Campanha da Cordilheira (1869-1870), estando presente no combate de Cerro Corá , onde é morto Solano Lopez. ${ }^{12}$

Floriano iniciou a guerra como Tenente e a terminou com a patente de Major. Assim como Deodoro, fez a guerra de cabo a rabo, sem intervalos para ver os seus no Brasil ${ }^{13}$. Durante o conflito, Floriano atuou em diversos postos, a saber Comandante da $4^{\mathrm{a}}$ Companhia do Batalhão de Engenheiros do $1^{\circ}$ Corpo de Exército do General Osório (1866-1867), Fiscal do $25^{\circ}$ Corpo de Voluntários da Pátria na Divisão do General Menna Barreto (1867-1868), Comandante do $44^{\circ}$ Corpo de Voluntários da Pátria do $3^{\circ}$ Corpo de Exército de Osório (1868), e, já promovido a Major, Comandante do $9^{\circ}$ Batalhão de Infantaria (1868-1870) ${ }^{14}$. Regressa à Corte em fins de setembro de 1870 (a guerra terminou em março), com a patente de Tenente-Coronel ${ }^{15}$, reluzente de condecorações militares ${ }^{16}$.

\section{4) O pós-guerra.}

Com o retorno à paz, afirma José Maria Bello (p. 84), a carreira de Floriano se burocratiza como as de tantos outros militares. Exerce diversas funções ligadas à administração militar, como a de Inspetor Encarregado das Fortificações e mais Obras Militares nas fronteiras de Mato Grosso (1870-1871), de membro da Comissão de Melhoramentos de Material do Exército (1871), de Diretor do Arsenal de Guerra de Pernambuco (1879-1880), de inspetor de Comandos e

\footnotetext{
${ }^{11}$ Salm de Miranda, pp. 30-33.

12 Para maiores detalhes sobre a participação de Floriano na Guerra do Paraguai, ver Salm de Miranda (cap. II) e Cyro Silva (cap. I).

13 Salm de Miranda, p. 47.

${ }^{14}$ Ver Salm de Miranda e Cyro Silva, mesmos capítulos.

${ }^{15}$ Salm de Miranda, p. 47.

${ }^{16}$ José Maria Bello, p. 84.
} 
Estabelecimentos Militares nas províncias da Paraíba, Pernambuco, Alagoas, Rio Grande do Norte e Sergipe (1881-1883). Nesse pós-guerra, Floriano também assume o Comando do $3^{\circ}$ Batalhão de Artilharia a Pé no Amazonas (1871-1872) e do $3^{\circ}$ Regimento de Artilharia a Cavalo em Alagoas, entre 1874, quando é promovido a Coronel, e $1878^{17}$.

Em 1883, é promovido a Brigadeiro (hoje General-de-Brigada ${ }^{18}$ ) e chega a exercer o Comando das Armas das províncias do Amazonas (1883-1884) e Pernambuco $(1884)^{19}$.

Enfim, em Carta Imperial de 9 de agosto de 1884, Floriano é nomeado Presidente e Comandante das Armas da Província de Mato Grosso ${ }^{20}$; é aqui que começa sua carreira política, e portanto veremos este ponto com mais detalhe.

\section{5) 0 progressismo militar ${ }^{21}$.}

Antes de abordarmos a carreira política de Floriano, seria necessário estudarmos brevemente as posições da oficialidade reformista do Exército imperial da segunda metade do século XIX, na medida em que essas posições, a nosso ver, terão peso nas atitudes políticas do Marechal de Ferro.

Com a reforma do Exército imperial de 1850, realizada pelo Ministro da Guerra Manoel Felizardo de Souza e Mello, foram instituídas normas rígidas de promoção por antiguidade, abolindo-se o sistema aristocrático que permitia a oficiais bem relacionados atingirem altos postos de comando com pouca idade. Passava-se também a escolher os oficiais-generais com base no critério do

\footnotetext{
${ }^{17}$ Sobre todas essas informações, ver Salm de Miranda, pp. 53-55.

${ }^{18}$ Para os nomes das patentes dos Exércitos luso-brasileiro e brasileiro na Colônia, no Império e na República, ver Gustavo Barroso, pp. 95 e 96.

${ }^{19}$ Ver Salm de Miranda, p. 55.

${ }^{20}$ Salm de Miranda, p. 55.

${ }^{21}$ Utilizaremos diversas vezes neste trabalho as expressões progressismo e progressista, que designariam aqui todos os indivíduos, grupos e correntes que pregam, no contexto de sociedades pré-capitalistas (ou seja, escravistas, de despotismo asiático ou feudais), o desenvolvimento econômico e o avanço social do país na direção do capitalismo, independentemente de suas opções políticas serem liberais ou autoritárias. Não há necessariamente relação sistemática entre liberalismo e progressismo de um lado e autoritarismo e reação de outro; podemos encontrar autoritarismos progressistas, cujo exemplo máximo seria a França napoleônica. Com isto queremos dizer que a passagem ao capitalismo pode se fazer politicamente tanto por uma via liberal (liberalismo clássico ou liberal-democracia) quanto por uma via autoritária.
} 
mérito, e exigia-se curso de nível universitário para os oficiais de Engenharia, Estado-Maior e Artilharia ${ }^{22}$. Embora a idéia do governo fosse criar uma geração de militares mais profissionais, assim como melhorar a precária estrutura militar do Império, acabou-se criando também uma classe meritocrática dentro de uma ordem escravista, o que, a longo prazo, geraria atritos. Com a reforma profissionalizante de 1850 , cria-se uma geração cuja ascensão na hierarquia profissional se baseia, pelo menos em tese, no mérito, e dessa forma acaba entrando em choque com o Estado escravista imperial, que por sua própria natureza vedava o acesso dos membros da classe escrava ao aparelho de Estado $^{23}$, e por isso negava o mérito pessoal. Ademais, esses oficiais com melhor educação e mais profissionalismo, tendo conhecimento da relação entre poderio militar e poderio industrial nas grandes potências européias, não podiam ver com bons olhos um Estado como o imperial, que, além de defender uma economia agrária, praticamente não tributava a classe dominante escravista ${ }^{24}$, o que o impedia de arrumar fundos para o setor público, inclusive o militar: em 1854-1855, era publicado, por jovens oficiais e estudantes militares, o jornal $\mathbf{O}$ Militar, que, a pretexto de protestar contra um projeto de lei que proibia jovens oficiais do Exército de se casarem sem o consentimento do Ministro da Guerra, passava a defender reformas profundas capazes de abalar a estrutura social da época; o jornal, que sairia, em segunda fase, em 1860-1861 (quando Floriano fazia seus estudos militares), defendia a abolição da escravidão, uma política de incentivo à imigração européia, o serviço militar obrigatório, o crédito liberal e tarifas protecionistas para a indústria, e a implantação de uma infraestrutura para o território brasileiro (construção de ferrovias, estradas e linhas telegráficas no

\footnotetext{
${ }^{22}$ John Schulz, O Exército na Política, pp. 26-27.

${ }^{23}$ Décio Saes, A Formação do Estado burguês no Brasil, p. 114.

${ }^{24}$ A este respeito, Décio Saes (A Formação do Estado burguês no Brasil, p. 151) afirma o seguinte: A lei de 1835 sobre tributação deixou de criar qualquer imposto territorial (...). Quanto ao imposto sobre a propriedade do escravo, ele existiu, mas jamais ultrapassou níveis insignificantes, salvo após 1850, quando o imposto sobre escravos urbanos foi elevado a fim de provocar a transferência de escravos para o campo (...). Como o consumo do trabalhador direto não podia ser tributado (como no capitalismo), pois este era dominantemente trabalhador escravo, a receita fiscal do Estado imperial (fundada sobretudo nos impostos sobre a exportação) foi claramente insuficiente para financiar as tarefas a cargo do Estado (despesas militares, estradas e portos, etc.).
} 
interior do país e nas áreas de fronteira ${ }^{25}$. Com a Guerra do Paraguai, que exigiu cinco anos de combate, resultou em 50 mil mortos do lado brasileiro ${ }^{26} \mathrm{e}$ determinou o aumento da dívida interna e externa do país ${ }^{27}$, bem como a alforria de escravos para preencher o vazio nas tropas $^{28}$ para vencer um inimigo irredutível, só veio a aumentar a convicção, por parte dessa oficialidade reformista, da fragilidade militar do Estado imperial escravista: ao propiciar o desnudamento das contradições fundamentais do Estado, a Guerra da Tríplice Aliança se tornou o fulcro das questões que iriam desdobrar-se nas décadas seguintes. Para os militares, ela revelava as raízes da fragilidade do Estado Imperial e fazia passar a sobrevivência e desenvolvimento da força profissional pela transformação do $E_{s t a d o}{ }^{29}$. Com a morte, em 1880, de Caxias, o "general dinástico", um oficial absolutamente leal à Monarquia e ao mesmo tempo uma liderança indiscutível dentro do Exército, que inclusive facilitava a submissão deste à ordem imperial ${ }^{30}$, a insatisfação de boa parte da oficialidade não é mais contida. A década de 1880 será a década da Questão Militar (1884-1887), onde qualquer desentendimento, por mais insignificante que fosse, entre um militar e um representante do establishment imperial, será pretexto para uma exteriorização da insatisfação da classe militar para com a ordem vigente ${ }^{31}$; será a década na qual, estando o

\footnotetext{
${ }^{25}$ Ver John Schulz, O Exército na Política, capítulo 2, onde o autor analisa minuciosamente as posições políticas defendidas por este periódico. No capítulo 4 (p. 87), Schulz cita o jornal A Tribuna Militar, que em 1881 defendia a abolição, a imigração, a construção de ferrovias e a proteção da indústria, provando que o pensamento modernizante de 0 Militar ainda era presente na década de 1880.

${ }^{26}$ John Schulz, O Exército na Política, p. 71.

${ }^{27}$ John Schulz, O Exército na Política, p. 73.

${ }^{28}$ Vítor Izecksohn, p. 87. Como afirma Wilma Peres Costa (pp. 298-299), a natureza da guerra - 0 enfrentamento com um exército de conscrição universal - fazia ressaltar na escravidão a causa fundamental do despreparo militar do Império e da inferioridade de seu exército perante o do inimigo. Ela frustrava os esforços de recrutamento, não apenas porque não se podia armar os escravos, mas porque impedia a participação de grande contingente de homens livres, ocupados em manter a disciplina no interior das fazendas, e também da Guarda Nacional, a força oligárquica mantenedora da ordem, particularmente refratária nas províncias com grande concentração de escravos, como Minas Gerais e São Paulo. É, portanto, a contradição entre o sistema escravista e a existência de um exército profissional de caráter nacional que emerge à consciência da oficialidade militar a partir da Guerra da Tríplice Aliança.

${ }^{29}$ Wilma Peres Costa, p. 305.

${ }^{30}$ Edmundo Campos Coelho, p. 68.

${ }^{31}$ Como observa Wilma Peres Costa (p. 20), nas duas décadas finais da monarquia, a Guerra da Tríplice Aliança se tornara uma espécie de "cadáver no armário" envenenando o relacionamento entre o exército e a coroa. A extrema sensibilidade em relação à experiência de guerra fora um dos
} 
Exército incumbido de substituir a Guarda Nacional na repressão às revoltas e fugas de escravos das fazendas, grande parte da oficialidade vai organizar a sabotagem dessa repressão, até o recém-fundado Clube Militar lançar em 1887 o famoso manifesto através do qual a classe armada se negava abertamente a perseguir os escravos fugidos ${ }^{32}$. Como bem afirma Jehovah Motta (pp. 183-184), o Império, com um Pedro II desatento aos sentimentos de insatisfação que se escondiam sob o formalismo da disciplina militar, com seus partidos e governos também alheios às mutações que se preparavam surdamente nos espíritos, não tinha ouvidos para ouvir proposições e apelos que tais, e aqueles majores e capitães acabaram sensíveis às pregações de Joaquim Nabuco e de Silva Jardim. "A escravidão é incompatível com um exército renovado"; "enquanto houver negro escravo, não haverá soldado-cidadão"; "monarquia é sinônimo de exército antiquado e ineficiente". Enfim, na década de 1880, o Estado imperial não conseguirá mais controlar parte de sua força armada.

Embora não queiramos fazer generalizações ao associarmos as posições políticas de determinados indivíduos à instituição e à época à qual pertencem, é interessante fazer a comparação entre oficiais de renome que entraram para o Exército antes e os que entraram depois da reforma de 1850. Os últimos, por terem uma formação mais complexa e moderna, tenderam a tomar posições políticas mais progressistas e menos conformistas que os primeiros, que em sua maioria tiveram formação militar mais antiquada e portanto exigiriam menos do Estado imperial. Entre os mais antigos encontramos oficiais como Deodoro e Pelotas, sentimentalmente ligados à Monarquia e que participaram da Questão Militar por espírito corporativo; entre os segundos, encontramos oficiais como Sena Madureira, Cunha Matos e Benjamin Constant, que se envolveram em

vetores principais da longa série de conflitos que marcaram a Questão Militar. Os principais oficiais envolvidos nos conflitos - Cunha Matos, Sena Madureira, Deodoro, Pelotas - tinham tido participação relevante na guerra, nela tendo sido feridos, feito prisioneiros, condecorados. $A$ condição de heróis de guerra que se apresentavam como vítimas do arbítrio dos políticos, tornavaos tributários de enorme solidariedade corporativa e aumentava-Ihes a visibilidade na opinião pública, emprestando às punições disciplinares por eles sofridas a aura do martírio.

32 Décio Saes, A Formação do Estado burguês no Brasil, p. 178. 
protestos contra o governo por insatisfação com a ordem vigente ${ }^{33}$. Floriano, como oficial que ingressou no Exército no final da década de 1850, se encaixaria, embora à sua maneira, neste último grupo.

\section{6) Presidente da Província de Mato Grosso (1884-1885).}

O contato do futuro Marechal de Ferro com a política é anterior a este período. Como afirma Lincoln de Abreu Penna ${ }^{34}$, nos tempos de aluno da Escola Militar Floriano já se tornara abolicionista e propagador da modernidade. Depois, em 1871, isto é, logo após o final da Guerra do Paraguai, organizava o Instituto Militar no intuito de defender os interesses do Exército como corporação e órgão político. Esta organização, de existência efêmera, já que seria dissolvida por ordem governamental no mesmo ano de sua criação (o Conselho de Estado e o próprio Caxias a viam como uma ameaça à disciplina militar), contou com a participação efetiva de futuros grandes nomes da alta oficialidade do Exército, como Severiano da Fonseca, José Clarindo de Queiroz, José de Almeida Barreto, José Simeão de Oliveira, Conrado Niemeyer, João de Oliveira Valporto e José Maria de Alencastro, e com a suposta presença de Sena Madureira, entre outros $^{35}$. Entretanto, pensamos nós, é com sua administração como Presidente de Mato Grosso, entre outubro de 1884 e outubro de $1885^{36}$, que algumas das principais tendências políticas de Floriano serão evidenciadas de fato pela primeira vez.

Segundo Roberto Macedo (p. 14), três pontos fundamentais assinalam a passagem de Floriano Peixoto pela Presidência de Mato Grosso: o problema do silvícola, a normalização das finanças e o primeiro impulso à exploração intensiva da erva mate. Nós acrescentaríamos outro ponto, que é a questão abolicionista.

\footnotetext{
${ }^{33}$ Ver John Schulz, O Exército na Política, cap. 5, e o cap. 4 do livro de Celso Castro, onde o contexto e os personagens da Questão Militar são muito bem estudados.

${ }^{34}$ O Progresso da Ordem, p. 147.

35 John Schulz, O Exército na Política, pp. 78-79.

${ }^{36}$ Salm de Miranda, pp. 55 e 60.
} 
Comecemos por este último. Como foi dito acima, Floriano já tomava posições abolicionistas quando aluno da Escola Militar. Quando Comandante das Armas da Província de Pernambuco (1884), Floriano dá todo seu apoio à causa abolicionista, o que Ihe valerá, em maio de 1884, o título de Sócio Honorário do Clube Ceará Livre, agremiação criada em Pernambuco para homenagear a Província do Ceará, que naquele ano abolia antecipadamente a escravidão em seu território ${ }^{37}$. Na Presidência de Mato Grosso, Floriano vai se ligar à corrente abolicionista local, colocando-se acima da disputas partidárias entre liberais e conservadores, embora estivesse filiado ao Partido Liberal ${ }^{38}$.

Quanto à questão indígena, esta era, naqueles tempos, problemática, devido à presença insuficiente das autoridades públicas na região. Como naqueles tempos os ataques dos índios bororos-coroados ${ }^{39}$ vitimavam, nas vizinhanças de Cuiabá, lavadeiras e agricultores com flechadas, uma das prioridades da administração de Floriano será o policiamento da região. Ao delimitar e cercar o habitat indígena, Floriano incumbe o Alferes Antônio José Duarte de comandar as forças de repressão e de pacificar os índios pelas armas ${ }^{40}$. Assim opina Roberto Macedo (p. 15) sobre o episódio: Militar até à medula, disciplinador irreprimível, Floriano, traído pelo seu temperamento, cometeu o erro de enfrentar o problema pela boca do fuzil. Egresso da guerra, não se lhe poderia exigir o milagre de transformar a farda em roupeta de missionário. A catequese leiga ainda não começara, pois o benemérito Rondon só veio a ser pressentido mais tarde, aliás pelo próprio Floriano.

Os dois outros pontos, a normalização das finanças e a indústria extrativa da erva mate, estão interligados. Como as fontes de receita davam uma renda inexpressiva para a Província $^{41}$, Floriano decide criar um imposto sobre a erva

\footnotetext{
${ }^{37}$ Cyro Silva, pp. 44-45.

${ }^{38}$ Salm de Miranda, p. 57. Não nos foi possível saber a data da filiação de Floriano ao Partido Liberal, mas o que nos é certo é que ela resultou da política imperial, preocupada com o prestígio adquirido pelo Exército depois da Guerra do Paraguai, de atrair seus oficiais para as fileiras dos dois grandes partidos monárquicos (José Maria Bello, p. 21).

${ }^{39}$ Salm de Miranda, p. 59.

${ }^{40}$ Roberto Macedo, p. 15.

${ }^{41}$ Roberto Macedo, p. 17.
} 
mate, alimento de grande consumo e artigo de exportação ${ }^{42}$. Este imposto sobre o mate exportado, além de aumentar a renda da Província, segundo Salm de Miranda (p. 60) também incentivou a formação de novos ervais.

Devemos agora caracterizar as principais tendências políticas da administração de Floriano Peixoto em Mato Grosso. Tais tendências se exprimirão, de certa forma, na orientação política que ele procurará aplicar quando à frente da Presidência da República. As tendências seriam duas:

a) $O$ progressismo. Floriano se revela um progressista ao se aliar com os grupos abolicionistas locais e ao dar impulso à principal atividade econômica da região, isto é a indústria extrativa do mate.

b) O fortalecimento do poder público. Ao criar o imposto sobre o mate exportado, Floriano aumenta a capacidade das autoridades da Província de formularem políticas públicas, e a violenta repressão aos ataques indígenas é uma forma do poder público se impor sobre os inimigos da ordem pública, mesmo que de forma não-conciliatória.

\section{7) Floriano e a Questão Militar.}

Floriano Peixoto não participa da Questão Militar (1884-1887) ${ }^{43}$. Aliás, um episódio ocorrido em 1883 e que é considerado um prenúncio da Questão Militar esteve relacionado exatamente a um protesto contra ele. Sua promoção ao generalato, em janeiro desse ano, irritou profundamente o Coronel Frias Vilar, que considerava injusto ter sido preterido nesta promoção em benefício de Floriano e que por causa disso ameaçava usar seu regimento contra o governo se não fosse promovido. Vilar, apoiado pelo jornal Nihilista, que se intitulava órgão dos trabalhadores, do Exército e da Marinha e acusava Floriano de ser um protegido das instituições, e pela Gazeta de Notícias, foi transferido para o Rio Grande do Sul e depois reformado por "motivos de saúde" ${ }^{44}$. De qualquer forma, após deixar

\footnotetext{
${ }^{42}$ Salm de Miranda, pp. 59-60.

${ }^{43}$ Cf. Salm de Miranda, p. 95.

${ }^{44}$ John Schulz, O Exército na Política, pp. 96-97.
} 
Mato Grosso em outubro de 1885, devido à queda do Gabinete Dantas, que era ligado ao Partido Liberal e que havia nomeado Floriano para esta província, e à ascensão do Gabinete Cotegipe, ligado ao Partido Conservador ${ }^{45}$, Floriano vai para Alagoas, onde permanece até novembro de 1888 para tratar da saúde abalada e de suas propriedades agrícolas ${ }^{46}$, e seu nome não será pronunciado durante toda a Questão Militar.

No nosso entender, não havia, no entanto, contraste entre as posições políticas de Floriano e as dos militares reformistas. Vejamos novamente as tendências políticas de sua administração em Mato Grosso:

a) O progressismo. Tanto o abolicionismo, quanto a defesa do desenvolvimento econômico são, como vimos, posições presentes dentro do Exército pelo menos desde a década de 1850.

b) O fortalecimento do poder público. Sendo o militar um funcionário do Estado, dificilmente poderia ele, pelo menos do ponto de vista profissional, ser contrário ao aumento da esfera de ação do poder público na vida do país. A própria repressão violenta aos inimigos da ordem pública (caso dos índios) seria, a nosso ver, oriunda de uma visão militar da política que encararia esses inimigos como "inimigos de guerra".

Portanto, não haveria dissonância significativa entre as posições políticas de Floriano e o pensamento progressista militar. Por que, então, Floriano não participa da Questão Militar? Poderiam ser alegados seus problemas pessoais (sua saúde e suas propriedades), sua disciplina, isto é seu suposto respeito pelas instituições monárquicas, o que Salm de Miranda tenta provar exaustivamente (pp. 94-107), ou até mesmo seu possível ressentimento em relação à questão Frias Vilar, que pode tê-lo feito identificar toda revolta militar contra o establishment imperial como uma revolta contra sua pessoa. Procuraremos, entretanto, levantar outra hipótese: Floriano, embora raciocinando como militar ao fazer sua política em Mato Grosso (modernização da economia e fortalecimento do poder público numa região de fronteira mal protegida contra a desordem interna e ataques

\footnotetext{
${ }^{45}$ Salm de Miranda, p. 61.

${ }^{46}$ Cyro Silva, p. 60.
} 
externos), não estaria agindo como representante da classe militar; melhor dizendo, embora Floriano tivesse em mente um programa político que coincidia com as aspirações militares (como veremos melhor ao estudarmos seu governo), ele estaria se colocando acima da instituição à qual pertencia, o que o impossibilitaria de agir em conjunto com seus companheiros de farda durante a Questão Militar, que em si seria um misto de ação política e reivindicação classista. A nosso ver, tal posição de Floriano terá peso em sua forma de governar durante a Presidência da República, e levá-lo-á, embora conquistando a simpatia de grande número de militares, a sofrer a oposição de muitos outros. Floriano se encontra na posição contraditória de ter uma mentalidade política militar inerente à sua formação profissional, mas de não querer se colocar como representante da classe militar em sua ação política.

\section{8) Floriano e a República.}

Na ocasião de sua nomeação para o Ministério da Guerra do Governo Provisório da República em abril de 1890, Floriano declarava que durante os últimos dezenove anos do Império fora republicano ${ }^{47}$. Neste início da República ficou-se sabendo que, quando esteve em Assunção no período final da guerra, Floriano teria, em reunião realizada numa loja maçônica, assumido o compromisso de entrar para a conspiração republicana em seu país ${ }^{48}$, adotando o pseudônimo de Guatemozin ${ }^{49}$. Segundo Salvador de Mendonça, Floriano seria o primeiro de uma lista de militares republicanos, secretamente alistados pelo Capitão Pompílio de Albuquerque ${ }^{50}$.

Embora muitas dessas informações venham de testemunhos e de boatos, podemos supor que Floriano Peixoto fosse republicano pelos menos desde a década de 1870; senão republicano convicto, pelo menos profundamente

\footnotetext{
${ }^{47}$ R. Magalhães Júnior, volume II, p. 199.

${ }^{48}$ Salm de Miranda, p. 100. Este biógrafo de Floriano, que insiste veementemente na fidelidade de Floriano para com as instituições monárquicas, nega tal boato (pp. 100-101).

${ }^{49}$ R. Magalhães Júnior, volume II, p. 200.

${ }^{50}$ R. Magalhães Júnior, volume II, p. 200.
} 
insatisfeito com a ordem monárquica e com a elite que ela representava ${ }^{51}$. Veremos agora as razões de seu republicanismo. Tobias Monteiro (p. 62) escreve, em obra publicada originalmente em 1913: Não há muito tempo, em artigo publicado na imprensa, referiu o General Cunha Matos que, voltando de assistir ao desfecho de Aquidabã, em que López morreu recusando render-se, dizia Floriano Peixoto, então major da coluna expedicionária: "De um homem daqueles é que nós carecemos no Brasil". A este respeito, podemos remeter a John Schulz (p. 72), segundo quem embora durante o período da guerra poucos oficiais tenham questionado o acerto da luta contra Lopez, vários deles - como foi o caso de Floriano Peixoto - passaram a admirar o ditador paraguaio por governar sem o estorvo de um sistema parlamentar ineficiente e corrupto ${ }^{52}$. Neste caso, Floriano defenderia a queda da monarquia parlamentar em benefício da instauração de um regime nacionalista que girasse em torno de uma liderança autoritária, e não necessariamente em benefício da República enquanto regime representativo.

O republicanismo de Floriano estaria também presente em seu meteórico Instituto Militar; entretanto, embora, segundo John Schulz (pp. 78-79), seja bem possível que Floriano e vários de seus colegas do Instituto defendessem idéias republicanas, a presidência da agremiação foi oferecida ao Conde d'Eu, que parece ter mantido relações cordiais com seus camaradas da Guerra do Paraguai,

\footnotetext{
${ }^{51}$ Serzedelo Corrêa, participante ativo da conspiração que derrubou o Império e integrante da pequena força insurrecinal de Deodoro e Benjamin Constant, escrevia em suas memórias (p. 19) a respeito de um dos episódios da Proclamação da República: Estávamos em 15 de novembro. Marchavam as tropas revolucionárias para o Campo de Santana, comandadas pelo major Sólon e Benjamin. Vínhamos pelo Mangue. Benjamin no centro, Pedro Paulino, irmão de Deodoro, a paisana, à esquerda, e eu, fardado, à direita, montados, à frente de dois pelotões da Escola Superior de Guerra, em infantaria. Não vendo Deodoro, e receando um combate ao entrarmos no Campo, interpelei Benjamin sobre quem comandava nossa força. Benjamin respondeu-me: Deodoro vem aí; mas se não vier, dê-me a sua palavra de honra que não dirá nada a ninguém! Se Deodoro não vier, comandará esta força o Floriano. Em outras passagens da mesma obra, o autor citado fala da conivência de Floriano com a conspiração republicana, o que, em caso de veracidade desses relatos, prova a indisposição do Marechal para com o regime deposto.

Observação: a ortografia dos trechos tirados das obras mais antigas foi adaptada para os dias atuais.

${ }^{52}$ Como afirma Wilma Peres Costa (p. 302), as raízes da incompatibilização dos militares com o sistema parlamentarista do Império estão também na Guerra da Tríplice Aliança e na forma como a dinâmica da guerra levou à colisão entre a racionalidade exigida pelas decisões e as práticas da política partidária tradicional. O loteamento político-partidário dos comandos, a vasta corrupção, a incompreensão do mundo político para com as dificuldades da campanha, foram alguns elementos dessa incompatibilização.
} 
além de ter tido amizade com o próprio Floriano ${ }^{53}$. Porém, anos mais tarde, mais precisamente em 10 de julho de 1887, Floriano escreve a famosa carta endereçada a seu amigo, o então Tenente-Coronel João Soares Neiva, carta onde diz o seguinte: Vi a solução da questão da classe, excedeu sem dúvida a expectativa de todos. Fato único, que prova exuberantemente a podridão que vai por este pobre país e, portanto necessidade da ditadura militar para expurga-la. Como liberal, que sou, não posso querer para meu país o governo da espada; mas não há quem desconheça e aí estão os exemplos de que é ele o que sabe purificar o sangue do corpo social, que como o nosso está corrompido ${ }^{54}$. Para Oliveiros S. Ferreira (p. 37), esta afirmação de Floriano, que ele inclusive compara com outra semelhante feita por Góis Monteiro na década de 1940, seria inerente ao pensamento militar, para o qual, quando há crise no sistema político ou no próprio sistema social, a culpa cabe às elites, que são "envilecidas". Entretanto, a admiração de Floriano por Solano López nos faz deduzir que ele não estaria desejando uma ditadura das Forças Armadas, e sim uma ditadura com base numa liderança forte e isolada no poder, uma liderança que, embora saída das fileiras militares, faria a sua própria política e não estaria representando a classe armada como um todo.

Seria errôneo associar o republicanismo de Floriano a uma tendência ideológica de cunho positivista. Um fato que prova o erro de tal interpretação é o episódio, ocorrido em setembro de 1892, durante seu mandato presidencial: a tentativa, por parte de Floriano, de mudar a bandeira republicana, eliminando a esfera azul celeste com o lema Ordem e Progresso, e colocando em seu lugar as armas nacionais. Floriano apresentou este projeto por intermédio do Coronel Valadão, seu secretário particular, à Câmara dos Deputados. A violenta reação dos alunos positivistas da Escola Superior de Guerra, uma de suas principais bases de apoio, que chegaram inclusive a irem intimida-lo pessoalmente no

\footnotetext{
${ }^{53}$ Ver John Schulz, O Exército e o Império, p. 239. Segundo este autor, Floriano, dispondo de poucas conexões por nascimento, teria criado as suas próprias com uma série de generais ligados ao Partido Liberal, como o Conde d'Eu, Osório e Pelotas.

${ }^{54}$ A versão integral da carta está em Tobias Monteiro, nota da p. 62. Este autor coloca a carta como sendo de 10 de julho 1889, mas Salm de Miranda (p. 96), após consultar o documento original, verificou ser a carta do ano de 1887 (quando é resolvida a Questão Militar), e provavelmente escrita no engenho Itamaracá, de propriedade de Floriano, em Alagoas.
} 
Palácio Itamaraty, levou-o a recuar e a conservar a bandeira positivista ${ }^{55}$. Embora, como veremos mais tarde, a jovem oficialidade positivista venha a apoiar Floriano em seu governo presidencial ${ }^{56}$, o Marechal de Ferro nunca será o representante do grupo positivista do Exército, outrora liderado por Benjamin Constant. O conservador Salm de Miranda (p. 125) atribui a não-filiação de Floriano ao pensamento positivista à sua "formação cristã". No entanto, o próprio Salm de Miranda afirma, nas pp. 324-325, que Floriano, ao contrário de sua mulher, não era católico praticante. No nosso entender, o fato de Floriano não se identificar com o positivismo não tem a ver com sua formação cristã ou com qualquer reação espiritualista ao materialismo positivista, mas sim com o fato de o Marechal de Ferro, embora tendo conhecimentos técnicos e científicos, ser um homem de tropa identificado com um pensamento de cunho militarista (daí sua opção por colocar as armas nacionais na bandeira republicana), avesso ao pacifismo da ideologia positivista, tão presente em Benjamin Constant e seus discípulos ${ }^{57}$, pacifismo que fazia com que os alunos da Escola Militar, na década de 1880, condenassem a ação brasileira no Paraguai ${ }^{58}$, ação da qual participara Floriano e que fora um trunfo em sua carreira. Além do mais, a admiração de Floriano por Solano López, líder belicoso do Paraguai, é outro indício de sua pouca identificação com o pacifismo dos positivistas.

Em suma, Floriano, republicano desde os tempos da Guerra do Paraguai, não seria propriamente republicano por ser defensor de um sistema político representativo, mas sim por ser avesso à ordem monárquica e escravista vigente. Sua admiração por Solano López, ditador do Paraguai, e sua defesa da ditadura militar nos fazem pensar que muito provavelmente optasse pela derrubada do trono em benefício de um regime controlado por uma liderança militar carismática e autoritária que se colocasse inclusive acima das próprias instituições militares. Este tipo de regime seria, para ele, a única forma de se concretizar uma política progressista de desenvolvimento dos potenciais econômicos brasileiros, sem os

\footnotetext{
${ }^{55}$ Custódio de Mello, $1^{\circ}$ tomo, p. 394 , e $2^{\circ}$ tomo, pp. 22-23.

${ }^{56}$ Celso Castro, p. 198.

${ }^{57}$ Ver Celso Castro, p. 67.

${ }^{58}$ Celso Castro, p. 141.
} 
"entraves" da legalidade (devemos nos lembrar que Floriano teve de deixar a Presidência e o Comando das Armas de Mato Grosso por causa de uma mudança de gabinete).

O papel de Floriano Peixoto na conspiração republicana será decisivo. Após permanecer cerca de três anos em Alagoas (onde chegou a pensar em pedir reforma para dedicar-se a atividades agropecuárias em suas propriedades) ${ }^{59}$, Floriano retorna à Corte, onde obtém a 8 de junho de 1889 a sua nomeação para Ajudante General do Exército ${ }^{60}$ e a sua promoção, a 3 de julho do mesmo ano, a Marechal-de-Campo (hoje General-de-Divisão ${ }^{61}$ ) pelo recém-instalado Gabinete Ouro Preto. O Visconde de Ouro Preto, crendo na suposta fidelidade de Floriano às instituições monárquicas, já que este ofocial não participara da Questão Militar $^{62}$, coloca, nesse momento de agonia do regime, seu correligionário do Partido Liberal na função de Ajudante-General do Exército, que corresponderia atualmente à de Chefe do Estado-Maior do Exército e que na época era a primeira autoridade militar do Império por ser imediato executor das ordens do Ministro da Guerra e por lhe caber a iniciativa da elaboração dos planos de campanha ${ }^{63}$, além de ser responsável pela disciplina no Exército, pelos suprimentos e pela administração geral, entre outros encargos ${ }^{64}$.

Durante a conspiração, o papel de Floriano será o de sabotagem da repressão à ação dos militares rebeldes. Sendo uma das funções do AjudanteGeneral, como vimos, a manutenção da disciplina dentro do Exército, Floriano, ao tomar conhecimento do andamento da conspiração militar que deveria derrubar o Gabinete Ouro Preto e junto com ele a própria Monarquia, faz vistas grossas: tranqüiliza Ouro Preto sobre os rumores de rebelião contra o governo, convencendo-o a confiar na fidelidade dos chefes militares e da guarnição ${ }^{65}$. No

\footnotetext{
${ }^{59}$ Salm de Miranda, p. 60.

${ }^{60}$ Salm de Miranda, p. 64.

${ }^{61}$ Ver Gustavo Barroso (pp. 95-96). Para a data de promoção de Floriano a Marechal-de-Campo, ver Salm de Miranda, p. 65.

62 José Maria dos Santos, Bernardino de Campos e o Partido Republicano Paulista, p. 87.

${ }^{63}$ R. Magalhães Júnior, $1^{\circ}$ volume, p. 188.

${ }^{64}$ Salm de Miranda, pp. 64-65.

${ }^{65}$ Tobias Monteiro, p. 119.
} 
dia 15 de novembro, quando a pequena força insurrecional comandada por Deodoro se dirige ao Campo de Santana, sede do Quartel General da Guerra e onde estavam reunidos os integrantes do Gabinete Ouro Preto, e lá recebe a adesão das forças militares e policiais que defendiam o local, Floriano, encarregado da repressão ao movimento insurrecional, não reage e se coloca do lado dos revoltosos ${ }^{66}$. O ministério era derrubado, Ouro Preto exilado e o Império recebia seu golpe de misericórdia; Floriano tivera papel-chave, facilitando a vitória da força insurrecional, e o golpe de Estado que derrubara a Monarquia fora incruento.

Sobre a atuação de Floriano no advento da República no Brasil, assim se exprime José Maria dos Santos ${ }^{67}$ : Em todo caso, não se poderá dizer que ele haja tido qualquer influência na Questão Militar, que tão profundamente repudiava, nem há prova alguma de se ter jamais posto em contato com Quintino Bocaiúva. A sua ação em tudo aquilo foi portanto indireta e sempre solitária. Pode mesmo dizer-se que foi apenas negativa, pois restringiu-se a imobilizar no quartel-general as tropas com as quais contava o governo para se defender.

Podemos acrescentar às tendências políticas apresentadas por Floriano Peixoto até as vésperas da República, isto é o republicanismo, o progressismo, o autoritarismo e a defesa de um fortalecimento do poder público, uma outra que aparece durante sua administração como Ministro da Guerra do Governo Provisório da República entre abril de 1890 e janeiro de 1891. Sua atuação neste ministério vai se caracterizar pelas seguintes preocupações:

a) A modernização do armamento. Quando Ministro da Guerra, Floriano, interessado na organização militar da Alemanha, "pátria da técnica marcial"68, incumbe oficiais de Estado-Maior do Exército de assistirem às experiências de canhões modernos naquele país ${ }^{69}$.

\footnotetext{
${ }^{66}$ Glauco Carneiro, pp. 43-44.

${ }^{67}$ Bernardino de Campos e o Partido Republicano Paulista, p. 88.

${ }^{68}$ Roberto Macedo, p. 23.

${ }^{69}$ Roberto Macedo, p. 23.
} 
b) A centralização das forças militares. Durante sua administração, Floriano se recusará a atender ao pedido, por parte de Estados como Pernambuco e Bahia, de fornecimento de armamento sofisticado às polícias estaduais, que deveriam aceitar apenas armamento condizente com sua função policial ${ }^{70}$.

c) A preocupação com as fronteiras brasileiras. Umas das principais preocupações da administração de Floriano na pasta da Guerra será a criação de colônias militares nas fronteiras ${ }^{71}$; Floriano será responsável pela instalação de uma colônia militar na foz do lguaçu ${ }^{72}$.

d) Os Arsenais de Guerra. Floriano proporá a Deodoro uma nova classificação dos arsenais de guerra no Brasil de modo a normaliza-la. A classificação resultante da reforma colocará o Arsenal do Rio de Janeiro na $1^{\text {a }}$ classe, o de Porto Alegre na $2^{\mathrm{a}}$, e os de Bahia, Pernambuco, Pará e Mato Grosso na $3^{\text {a } 73 \text {. }}$

Estas quatro características da administração de Floriano revelam outra tendência, inerente à sua condição profissional de militar, de modernizar a estrutura militar brasileira, o que vale dizer aprimorar o sistema de defesa do território brasileiro, adotando armamento moderno, evitando-se a formação de exércitos regionais (caso do armamento das polícias estaduais), ocupando militarmente as fronteiras (colônias militares) e reorganizando o equipamento militar (arsenais).

Concluindo, podemos afirmar, portanto, que, ao chegar ao poder presidencial em 23 de novembro de 1891. Floriano já teria apresentado as seguintes tendências políticas e ideológicas: o republicanismo (ou o desejo de derrubar o Império e sua elite retrógrada), o progressismo (ou a preocupação em modernizar o Brasil), o fortalecimento do poder público, e a modernização da organização militar. Todas essas tendências políticas de Floriano, sendo inerentes à sua condição de militar, não o farão, entretanto, representante do Exército ou das Forças Armadas em sua ação política: sua ausência na Questão

\footnotetext{
${ }^{70}$ Roberto Macedo, p. 25.

${ }^{71}$ Roberto Macedo, p. 27.

${ }^{72}$ Roberto Macedo, p. 29.

${ }^{73}$ Roberto Macedo, p. 24.
} 
Militar, quando até militares monarquistas como Deodoro e Pelotas se colocam como representantes de seus colegas de farda descontentes, nos faz deduzir que o futuro Marechal de Ferro procura fazer sua política individualmente, colocandose politicamente acima da corporação à qual pertence, o que será visto de forma mais nítida depois.

B) O Governo Floriano (1891-1894): principais aspectos.

Passaremos agora ao levantamento dos principais aspectos de seu governo presidencial, levantamento que nos será útil para a análise da conjuntura histórica que faremos nos próximos capítulos do nosso trabalho.

A nosso ver, os principais aspectos deste governo de cunho nacionalista seriam o progressismo, o autoritarismo, o fortalecimento do poder público e uma política externa agressiva. Veremos estes pontos um por um.

\section{1) O progressismo.}

O progressismo do governo presidencial de Floriano Peixoto se exprime através de medidas visando modernizar o Brasil.

Em 12 de maio de 1892, Floriano apresenta ao Congresso um programa político propondo uma reforma fiscal, a reestruturação do sistema bancário ${ }^{74}$, o estímulo à indústria, a construção de estradas de ferro, a expansão da educação, a construção de uma nova capital federal no Planalto Central, a manutenção do Tratado Mendonça-Blaine ${ }^{75}$ e o saneamento da cidade do Rio de Janeiro, na época assolada pela febre amarela ${ }^{76}$.

\footnotetext{
${ }^{74}$ Veremos estes dois primeiros pontos no terceiro capítulo da dissertação, no estudo do contexto do combate do Governo Floriano aos grupos que se beneficiaram do Encilhamento.

${ }_{75}$ Tratado assinado em princípios de 1891, ainda durante o Governo Provisório, com os Estados Unidos, e segundo o qual era permitida a entrada do açúcar, da borracha e do café brasileiros com impostos reduzidos nesse país, em troca de tarifas mais baixas para vários produtos industriais norte-americanos no Brasil. Embora fortemente criticado aqui, inclusive pela elite cafeeira paulista na medida em que o seu produto já dominava o mercado norte-americano sem ele, esse tratado acabou por favorecer a economia açucareira do Nordeste, ao contrário da indústria dos Estados Unidos, cujas vendas para o Brasil não tiveram aumento significativo. O Tratado será cancelado por própria decisão dos Estados Unidos em 1894 (John Schulz, O Exército na Política, p. 161).
} 
O governo de Floriano, sobretudo durante o período em que Serzedelo Correa ocupa a pasta da Fazenda (agosto de 1892 a abril de 1893) ${ }^{77}$, tem uma orientação industrializante: encontramos uma política de fornecimento de crédito especial à indústria ${ }^{78}$ e medidas protecionistas para determinadas empresas depois do exame da situação de cada uma ${ }^{79}$.

Quanto à construção da nova Capital Federal no Planalto Central, prevista na Constituição republicana de $1891^{80}$, Floriano nomeia em 1892 uma comissão chefiada pelo engenheiro Luiz Cruls para reconhecimento e demarcação da área escolhida ${ }^{81}$; a comissão terminará seus trabalhos em 1894, fixando um espaço conhecido como Retângulo ou Quadrilátero de Cruls, que servirá de base, décadas mais tarde, para a construção de Brasília ${ }^{82}$. Podemos encontrar aqui mais uma preocupação de cunho militar de transferir a Capital Federal da vulnerável região litorânea para a região central, sendo esta mais protegida de ataques externos num país de tamanho continental como o Brasil.

Durante o ano de 1892, o governo florianista será prolífico no aprimoramento da infraestrutura do território brasileiro: ele autoriza e concede créditos, após estudos e comissões de técnicos, para obras portuárias em Santos, Recife, Salvador, Rio de Janeiro, Torres, Ceará, Vitória, Sergipe e Alagoas, estimula o fortalecimento de empresas de navegação existentes, ou o aumento de sua tonelagem, e a criação de novas, determina a desobstrução de rios e o estabelecimento da navegação no rio das Velhas e no rio São Francisco, prolonga os principais eixos ferroviários e inicia ou dá continuidade à construção de ramais do interesse de várias regiões econômicas ou estratégicas, regulamenta a repartição de Terras e Colonização e firma contratos sobre imigração e colonização, faz construir poços artesianos, açudes e represas de rios no Piauí e

Talvez por favorecer a venda do açúcar nordestino sem prejudicar realmente a incipiente indústria brasileira, é que o nacionalista Floriano Peixoto decidirá manter o Tratado, fora as tendências próamericanas de sua política externa, o que veremos depois.

${ }^{76}$ John Schulz, O Exército na Política, p. 176.

${ }_{77}$ Para essas datas, ver Roberto Macedo, pp. 82 e 86.

${ }^{78}$ História Nova do Brasil, p. 125.

${ }^{79}$ História Nova do Brasil, p. 129.

${ }^{80}$ Fernando H. Mendes de Almeida, pp.103-104.

${ }^{81}$ Ver Shuiguenoli Miyamoto, p. 163, e Cyro Silva, p. 124.

${ }^{82}$ Shiguenoli Miyamoto, pp. 163-169. 
na Paraíba para o combate à seca, e incentiva a mineração do ouro e dos fosfatos e a indústria das salinas ${ }^{83}$.

Os esforços de Floriano no aperfeiçoamento da instrução pública se fazem também em 1892, com a regulamentação do ensino secundário, a nomeação de professores, a criação de estabelecimentos de ensino, a autorização aos Estados e a particulares para fundarem estabelecimentos de ensino superior, a regulamentação do Ginásio Nacional, a fundação do Pedagogium para a formação e o aperfeiçoamento de professores e os regulamentos da Biblioteca Nacional, do Museu Nacional e do Instituto Nacional de Música ${ }^{84}$.

Se durante sua administração em Mato Grosso (1884-1885) Floriano dava indícios de progressismo, durante seu mandato presidencial sua defesa do progresso e da modernidade estão comprovados. Seu governo à frente da Presidência da República se encaixa ainda melhor dentro do progressismo militar da segunda metade do século XIX, porque encontramos aqui as mesmas reivindicações de jornais como 0 Militar e a Tribuna Militar: a proteção e o incentivo à indústria, o investimento em infraestrutura e transportes, uma política de imigração e colonização. O próprio investimento em educação deveria satisfazer as aspirações militares daqueles tempos, já que a instrução da população é um passo para a conscientização de sua nacionalidade e, conseqüentemente, para o preparo cívico na defesa do território nacional em caso de agressão externa. Em suma, a administração florianista revela as preocupações de um militar com a integridade do gigantesco território brasileiro, e a idéia de que a melhor forma de protege-lo contra ataques externos e movimentos separatistas é a dinamização de suas atividades econômicas e a interligação entre suas diversas regiões.

\footnotetext{
${ }^{83}$ Para todas essas informações, ver Salm de Miranda, pp. 192-194.

${ }^{84}$ Salm de Miranda, pp. 192-194.
} 


\section{2) $O$ autoritarismo.}

Como veremos no capítulo sobre o contexto histórico do Florianismo no poder, Floriano dará demonstrações de seu autoritarismo através de prisões, deportações, deposições de governos estaduais e estado de sítio (colocamos a parte a violência das revoltas, já que os episódios sangrentos do período 18931895 ocorrerão sobretudo por causa de um contexto de guerra civil).

O autoritarismo de Floriano seria intrínseco à sua condição de militar, como vimos na síntese biográfica. José Maria dos Santos ${ }^{85}$, embora suspeito por sua admiração incondicional pela monarquia de Pedro II, faz uma observação interessante sobre o caráter militar da política florianista de deposição dos governadores deodoristas: O Marechal Floriano Peixoto organizou os governos dos Estados imediatamente atingidos pelas deposições, com a mesma superior independência com que um chefe de exército designaria novos comandantes para batalhões em crise de disciplina. Entretanto, não poderíamos considerar o autoritarismo florianista como ação política das Forças Armadas. Da mesma forma que Floriano não tomou parte na Questão Militar por se colocar acima da própria classe, embora se identificasse com as aspirações políticas da oficialidade progressista do Exército, seu governo presidencial não será uma representação política do Exército e das Forças Armadas na medida em que ele se colocará acima deles. Uma prova disso será a reforma, a prisão e a deportação de vários altos oficiais do Exército e da Marinha, que se opunham publicamente ao seu governo, em abril de $1892^{86}$. Aliás, como afirma Oliveiros S. Ferreira (p. 89), exceto pelo "jacobinismo", porém, não houve, em seu governo, ações que tivessem marcado a filiação, "espiritual" que fosse, do "marechal de ferro" ao Partido Fardado ${ }^{87}$. A energia que pôs na resposta ao manifesto dos generais prendendo, desterrando e reformando - embora extremada, não é marca registrada do Partido Fardado; é, antes, própria de um chefe de Estado e de um

\footnotetext{
${ }^{85}$ A Política Geral do Brasil, p. 219.

${ }^{86}$ Ver Edgard Carone, A República Velha (Evolução Política), pp. 94-95.

${ }^{87}$ Expressão empregada pelo autor citado (ver cap. VI) para designar a intervenção de militares na política; veremos com mais detalhe este conceito quando estudarmos, no próximo capítulo, a ação política de Deodoro.
} 
comandante-chefe cônscio de sua posição e de suas prerrogativas. E a prisão de senadores, se indica menosprezo pelos ritos democráticos, está, enquanto gesto político e seu significado, muito aquém do que se podia depreender da leitura da famosa carta escrita depois de terminada a Questão Militar, em que diz que apenas o regime da espada salvaria o país. A nomeação, por parte de Floriano no contexto da deposição dos governadores deodoristas (novembro de 1891 a março de 1892), do Capitão Barbosa Lima, um representante dos oficiais intermediários do Exército, para o governo de Pernambuco ${ }^{88}$ seria a nosso ver um indício de sua tendência a desconsiderar a hierarquia militar em suas ações políticas: na instituição militar a hierarquia é um princípio, e a hierarquia militar dificilmente poderia aceitar que oficiais inferiores, intermediários, e até superiores, dessem ordens a oficiais-generais apenas pelo fato daqueles ocuparem cargos políticos e estes não. Veremos depois como Floriano irá se afastar de oficiais generais e superiores politicamente atuantes tanto do Exército quanto da Marinha, como José Simeão de Oliveira, Custódio de Melo, Serzedelo Corrêa, Sólon Ribeiro e Eduardo Wandenkolk, e se cercar de militares que, embora com prestígio em suas armas, eram politicamente inexpressivos ou secundários, como Francisco de Moura, Artur Oscar, Moreira César, Gomes Carneiro, oficiais cujo prestígio político será adquirido dentro do Florianismo (encontraremos, como veremos depois, também nas hostes florianistas uma jovem oficialidade positivista, que, embora politicamente atuante, não se encontrava entre os oficiais generais, e portanto não tinha o mesmo peso político que grande parte dos adversários militares do Marechal de Ferro).

Floriano também não representaria nenhuma facção política específica. Um indício disso seria a vertiginosa relação de ministros (muito bem estudada por Roberto Macedo, pp. 73-130), durante seus três anos de governo: no total foram 39 ministros $^{89}$, sendo por exemplo dez (7 efetivos e 3 interinos) para a pasta do Exterior $^{90}$. Mesmo as pastas militares sofreram mudanças: dois ministros efetivos

\footnotetext{
${ }^{88}$ Edgard Carone, A República Velha (Evolução Política), pp. 81 e 82.

${ }^{89}$ Salm de Miranda, p. 194.

${ }^{90}$ Roberto Macedo, pp. 91-95.
} 
ocuparam a pasta da Guerra, e cinco a da Marinha ${ }^{91}$. Como afirma Salm de Miranda (p. 194), os seus ministros se substituem por motivos vários, de uma para outra pasta, de ministro para outros cargos no país e no estrangeiro; estes porque têm razões de ordem política, ou porque acham mais cômodo passar para o outro lado e engrossar as fileiras da rebelião em marcha. Floriano não se agasta, nem se perturba, porque quem impulsiona o governo e aciona os ministros é ele. A intervenção constante de Floriano nos assuntos de cada pasta provoca essa dança de ministros: Cético sobre o valor dos homens, o chefe do Governo pouca importância ligava às aptidões especiais que pudessem revelar. Os seus auxiliares viviam em constante contradança, de uma pasta para outra, por vezes acumulando várias delas. O Governo era ele, a sua desconfiada vigilância, a sua disfarçada vontade de domínio... ${ }^{92}$. Dificilmente o representante de uma facção política no poder poderia intervir e mexer em todos os ministérios de seu governo de forma a ser onipresente em todos os seus ramos, já que nesse caso os ministros deveriam ser logicamente integrantes dessa facção e, portanto, sua posição deveria ser respeitada pelo Chefe de Estado; Floriano representaria na verdade uma tendência política de militar progressista, e não um partido.

O Governo Floriano parece ter sido um governo baseado no poder pessoal do Chefe de Estado, isto é um governo autoritário que se colocaria acima das Forças Armadas e dos diversos grupos políticos. Politicamente, Floriano teria buscado a instauração de um governo pessoal, embora ideologicamente estivesse afinado com a oficialidade progressista do Exército brasileiro da segunda metade do século XIX.

\section{3) O fortalecimento do poder público.}

Para Lincoln de Abreu Penna ${ }^{93}$, a par da tarefa de eliminar seus opositores mais tenazes, Floriano conquistou o Estado através de uma silenciosa operação

\footnotetext{
${ }^{91}$ Roberto Macedo, pp. 101-130.

92 José Maria Bello, p. 88.

${ }^{93}$ O Progresso da Ordem, pp. 161-162.
} 
que consistiu em ampliá-lo burocrática e administrativamente, e confiar a máquina governamental às pessoas de sua mais estrita confiança. Poderíamos também encontrar um aumento da presença do Estado na política de combate aos especuladores na cidade do Rio de Janeiro: Floriano decreta baixa no aluguel das casas de operários, intervem no mercado de carne, concedendo isenção de impostos sobre o gado de pé e sobre a carne à venda nos açougues, promovendo assim a queda de preços; combate, através da ação de Barata Ribeiro, prefeito do Distrito Federal nomeado por ele, a monopolização do fornecimento de carnes por alguns poucos grupos, do gado lanígero pelo gado importado do exterior e da venda do pescado, faz demolir o cortiço cabeça de porco, pertencente ao Conde d'Eu, e decreta lei ordenando a criação de casas populares e operárias ${ }^{94}$.

Todas essas medidas representam uma política de fortalecimento do poder público, já que este passa a se impor sobre negócios particulares; este fortalecimento do Estado tem uma função progressista na medida em que ele significa um aumento do combate a grupos que prejudicam as camadas pobres e a sociedade em geral em benefício de seus próprios proveitos. É claro que o fortalecimento do Estado está também presente nas medidas de Floriano expostas no estudo dos dois primeiros aspectos de seu governo logo acima, mas procuramos dedicar uma parte ao aumento da esfera de ação do Estado frente aos grupos privados e especuladores do Rio de Janeiro, já que o controle dos preços e o combate aos monopólios são características típicas de um poder público que procura se fortalecer.

\section{4) Uma política externa agressiva.}

A política externa do governo de Floriano Peixoto será turbulenta. Poderíamos citar as tradicionais tensões entre o Brasil e seu incômodo vizinho, a Argentina $^{95}$, mas o que nos interessa aqui é o caráter anti-europeu dessa política:

\footnotetext{
${ }^{94}$ Ver História Nova do Brasil, pp. 130-134.

${ }^{95}$ Sérgio Corrêa da Costa (p. 179) fala de preparativos, no Brasil, em 1892, para uma eventual guerra com a Argentina, que, segundo o Conde de Paço d' Arcos, ministro português no Brasil, em relatório ao governo de seu país, estaria cobiçando o Mato Grosso e o Rio Grande do Sul.
} 
Floriano desdenha, por exemplo, os representantes diplomáticos de França e Inglaterra ${ }^{96}$, e o rompimento das relações diplomáticas com Portugal por ocasião da Revolta da Armada, rompimento que não deixará de influir no futuro político do Florianismo, é um grande exemplo desta tendência. Por outro lado, ao mesmo tempo em que é anti-europeu, o Governo Floriano é favorável aos Estados Unidos, a jovem potência republicana do Novo Mundo, o que será provado com a aproximação entre os dois países durante a Revolta da Armada, assim como pelo apoio militar norte-americano ao Marechal de Ferro durante esta revolta ${ }^{97}$.

Recapitulando, podemos afirmar que o governo de Floriano Peixoto foi progressista, por tomar medidas visando a modernização do Brasil, autoritário e pessoal, por procurar submeter a oposição pela força e por se colocar acima das facções políticas e das próprias Forças Armadas, intervencionista, por procurar aumentar a participação do poder público na vida do país enfrentando o poder de grupos privados, e agressivo com os países que mostrariam tendências a prejudicar a República e o Brasil. Reencontramos, no caso do preparo para uma eventual guerra com a Argentina ${ }^{98}$, a preocupação de Floriano para com a modernização e o equipamento das Forças Armadas brasileiras, e ressaltamos, ao abordarmos sua aproximação diplomática com os Estados Unidos, o caráter pró-americano e anti-europeu de sua política externa.

\section{C) Os florianistas.}

\section{1) Florianismo de governo e florianismo de rua.}

Para Lincoln de Abreu Penna ${ }^{99}$, o florianismo comportou duas tendências, a que denominamos florianismo de governo e a que designamos florianismo de rua. $\mathrm{Na}$ primeira, encontram-se os que sustentaram organicamente a política do

\footnotetext{
${ }^{96}$ Ver Sérgio Corrêa da Costa, pp. 179-181.

${ }^{97}$ Sérgio Corrêa da Costa, pp. 49-50.

${ }^{98}$ Sérgio Corrêa da Costa, p. 179.

${ }^{99}$ O Progresso da Ordem, p. 15.
} 
Marechal, no congresso e especialmente nas Forças Armadas, bem como através do Partido Republicano Federal. Nesta vertente, o florianismo não chegou a se situar como uma expressão original na política, não se caracterizando enquanto fenômeno político. Ao contrário, o florianismo de rua, espontâneo e dissociado dos canais convencionais, foi a mais pura adesão a uma liderança política convencional ignorando as instituições e mantendo com o Marechal uma relação de absoluta fidelidade.

No que diz respeito ao florianismo de governo, poderíamos dizer que, fora os militares (Moreira César, Artur Oscar, Lauro Sodré, etc.) que defendem convictamente a política do Marechal em suas ações, sejam essas ações políticas ou propriamente militares, a ligação de grupos políticos da elite e de integrantes do aparelho de Estado à política de Floriano é ocasional, isto é, só se fará devido ao contexto político do momento. Como veremos posteriormente, a aliança de políticos como Francisco Glicério, Manuel Vitorino e do próprio Partido Republicano Paulista com o Florianismo de forma alguma poderá ser considerada como ideológica, e sim como tática. De qualquer forma, o Partido Republicano Federal, sob o controle de Glicério, será o grande meio de organização das bases de apoio do Florianismo dentro do aparelho de Estado ${ }^{100}$, sobretudo, a nosso ver, no que diz respeito à arregimentação da elite civil em torno de um fenômeno político-militar.

O conteúdo ideológico do Florianismo seria em parte dado por uma ala do Exército que se identificava com as aspirações políticas do Marechal de Ferro. $\mathrm{O}$ militar florianista típico seria o homem de tropa, com fortes tendências nacionalistas, defensor do progresso e republicano convicto, embora não tenha tido participação de destaque na conspiração republicana e na Proclamação; encontraríamos este perfil em Moreira César, Artur Oscar, Argolo e Francisco de Moura, cada um tendo um papel importante na luta do Florianismo contra seus adversários políticos ${ }^{101}$. A esse militar de tipo troupier, se juntará o militar positivista discípulo de Benjamin Constant e que, com a morte deste em janeiro de

\footnotetext{
${ }^{100}$ Lincoln de Abreu Penna, O Progresso da Ordem, p. 169.

${ }^{101}$ A ação desses militares será mencionada no terceiro capítulo.
} 
1891, ficou sem referencial político. Embora tivesse formação em engenharia militar e fosse bacharel em ciências físicas e matemáticas ${ }^{102}$, em seu tempo de aluno Floriano era mais conhecido pela força física, pela habilidade no manejo das armas e pelas lutas de rua com os capoeiras no Rio de Janeiro ${ }^{103}$, e seu desempenho nos cursos teóricos teria sido um tanto medíocre, já que chegou a ser reprovado na Escola Militar, no ano de $1860^{104}$; portanto, Floriano também se encaixaria dentro do perfil do troupier, e dificilmente poderia ele se identificar com a oficialidade positivista representada por Benjamin Constant, o brilhante professor de matemática da Escola Militar. Mas, alguns elementos ideológicos, de grande importância, uniriam os militares positivistas aos florianistas, isto é a ideologia republicana, o progressismo e o autoritarismo: o republicanismo de Benjamin Constant e de seus alunos na Praia Vermelha é incontestável, como bem nos mostra Celso Castro (pp. 79-84 e cap. 7); a ideologia positivista, por sua apologia da ciência e da sociedade industrial ${ }^{105}$, é nitidamente progressista e modernizadora; a visão autoritária e hierárquica do pensamento comteano, que defende uma sociedade governada por uma nova elite científico-industrial ${ }^{106}$, se encaixa bem no autoritarismo militar florianista. Floriano de certa forma encarnaria a figura do ditador republicano pregada pelos positivistas: os positivistas, que não haviam conseguido converter o impulsivo Deodoro no ditador ideal da República, começam a endeusar-Ihe o substituto ${ }^{107}$. Portanto, o Florianismo uniria militares de tipo troupier com tendências republicanas, autoritárias e progressistas e militares positivistas, representados por jovens oficiais do Exército e alunos militares discípulos de Benjamin Constant, como Lauro Sodré, Barbosa Lima, Tasso Fragoso, Ximeno de Villeroy, Cândido Rondon, Lauro Müller e Serzedelo Corrêa ${ }^{108}$

\footnotetext{
102 Salm de Miranda, p. 54.

103 Segundo depoimento do Coronel Arnaldo Guimarães, Floriano, em seus tempos de cadete no Rio de Janeiro, teria entrado em combate de rua com o famoso capoeira Manduca da Praia em defesa de seus colegas, saindo-se vitorioso (ver Lincoln de Abreu Penna, Por que somos Florianistas?, pp. 72-74).

${ }^{104}$ Salm de Miranda, p. 26.

${ }^{105}$ Celso Castro, pp. 63-64.

${ }^{106}$ Celso Castro, p. 64.

107 José Maria Bello, p. 91.

108 Ver Celso Castro, pp. 195-200, onde a ação política dos jovens oficiais "científicos" (assim chamados por sua formação aprofundada em engenharia, matemática e disciplinas científicas) nos cinco primeiros anos da República é analisada de forma sintética.
} 
(antes deste último romper com Floriano para posteriormente aderir à Revolta da Armada), a Escola Militar da Praia Vermelha vindo a se transformar num dos apoios mais sólidos do Marechal de Ferro ${ }^{109}$. Este apoio dos positivistas, aliás, era recíproco, já que Floriano, embora não fosse positivista, simpatizava com os oficiais reformistas seguidores de Benjamin Constant e utilizou como pode seus serviços $^{110}$. Como afirma Jehovah Motta (p. 251), a Escola, com grande acuidade, soube ver, por entre o cipoal dos interesses e das paixões, que Floriano, naquela hora, encarnava a causa republicana. E deu-Ihe, em crença e fervor, o que já dera a Benjamin ao tempo da propaganda e da proclamação. Fez-se florianista, empolgada pela mística da defesa da República a todo transe.

O florianismo de rua, fenômeno essencialmente carioca, estaria ligado a grupos habitualmente excluídos do jogo político. Em parte essa ala do Florianismo estaria representada em grupos marginais: Esse "mundo da desordem", que inspirava a reflexão dos mais atentos cronistas da época, caracterizou o modo de ser do Rio no último quarto de século. O convívio com os segmentos sociais marginalizados dotou a camada culta e intelectualizada da cidade de uma sensibilidade para a problemática social e política. Esta relação intensamente vivida na boemia operou um significativo fenômeno, que consistiu no desejo de incorporar aos costumes essa forma de cidadania. Neste espaço tolerado, no qual coexistiam letrados e iletrados, homens de ação e vadios, e que encontravam na prostituição e na bebida o lazer desconhecido pela população trabalhadora, surgia o embrião de uma república às avessas daquela que detinha o poder das leis. Neste meio arredio aos políticos e às instituições, contou Floriano com decisivo apoio $^{111}$. Certamente as medidas populares que Floriano tomou, como a redução dos preços dos aluguéis e de artigos no comércio, conquistaram a simpatia das

\footnotetext{
${ }^{109}$ Celso Castro, p. 198.

110 John Schulz, O Exército na Política, p. 152.

111 Lincoln de Abreu Penna, O Progresso da Ordem, pp. 153-154. José Murilo de Carvalho (Os Bestializados, tabela da p. 75) nota que em 1890 essa camada sub-proletária (que o autor chama de proletariado, em contraste com o operariado que trabalhava na extração, na manufatura, nos transportes ou como artistas) composta de jornaleiros, de pessoas ligadas ao serviço doméstico e outros, representava 46,5\% da população economicamente ativa do Rio de Janeiro, num total de 264233 pessoas profissionalmente ocupadas.
} 
camadas pobres cariocas, mas outro fator determinante para essa caracterização do Florianismo como uma espécie de movimento de massa é o fato de que essas camadas marginalizadas, numa cidade onde o eleitorado potencial era de cerca de um quinto da população total ${ }^{112}$, estando excluídas da política formal, precisavam se projetar numa liderança autoritária que se colocasse acima das instituições políticas, acima das manobras parlamentares, acima dos processos eleitorais e acima da oligarquia política.

O florianismo de rua estará presente nos Batalhões Patrióticos, formados para a defesa da República, associada à figura do Marechal de Ferro, contra a tentativa restauradora identificada na Revolta da Armada, mas o conteúdo ideológico do Florianismo enquanto corrente política não-convencional será dado pelo jacobinismo.

\section{2) Os jacobinos.}

Esta corrente política representa a ala mais radical do Florianismo, e podese até dizer que ela será responsável pela crescente radicalização deste. $O$ jacobinismo brasileiro, ou melhor carioca, já que o Rio de Janeiro será de longe o foco mais importante do movimento, dura de 1893, quando a explosão da Revolta da Armada arregimenta os radicais republicanos e seguidores de Floriano na luta pela defesa de seu governo, até 1897, quando o atentado frustrado a Prudente de Moraes, atentado do qual participarão elementos jacobinos, desmoraliza completamente os representantes desta corrente ${ }^{113}$. Este movimento, composto em grande parte de militares (majores, capitães, tenentes, alferes ${ }^{114}$ ), de pequenos comerciantes, de funcionários públicos, de farmacêuticos e de guarda-

112 José Murilo de Carvalho, Os Bestializados, p. 85, expõe uma tabela sobre o eleitorado potencial do Rio de Janeiro em 1890, que seria de 109421 indivíduos numa população de 515 559: a baixa proporção de eleitores se explica pela exclusão de menores de 21 anos, mulheres, analfabetos, praças de pré e frades. No entanto, foram apenas alistados 28585 eleitores, ou seja $28 \%$ do eleitorado potencial, nas eleições para a Constituinte do mesmo ano (ver mesma página), o que indica um alto índice de abstencionismo e um direito de votar reservado de fato a uma elite.

${ }^{113}$ Ver o cap. Tessitura do quadro histórico, do livro de Suely Robles Reis de Queiroz, onde a autora expõe a evolução do jacobinismo dentro do contexto histórico brasileiro no período 18931897.

${ }^{114}$ Suely Robles Reis de Queiroz, p. 232. 
livros $^{115}$, nos mostra que pode haver grande identidade entre o radicalismo de alguns setores das camadas médias urbanas e as aspirações políticas de uma ala do Exército. A ação política dos seguidores desta corrente se fazia através da imprensa (jornais $\mathbf{O}$ Jacobino e $\mathbf{O}$ Nacional, por exemplo ${ }^{116}$ ), de clubes $^{117}$, de meetings e da ação parlamentar de políticos, civis ou militares, como Frederico Borges, Érico Coelho, Timóteo da Costa, Barbosa Lima, Lauro Sodré, César Zama, Nilo Peçanha e Alcindo Guanabara, sem entretanto se concretizar num partido formalizado ${ }^{118}$.

As principais características deste jacobinismo brasileiro seriam: um nacionalismo fervoroso, que se traduz numa defesa aguerrida da soberania nacional contra o imperialismo europeu (mas ao mesmo tempo tendo uma visão positiva dos Estados Unidos, a grande nação republicana e potência emergente do continente americano) e numa defesa da nacionalização de algumas atividades econômicas; um culto à República e a defesa de qualquer meio de preserva-la contra seus inimigos; uma xenofobia visando os imigrantes de origem européia, especialmente os portugueses, controladores de boa parte do comércio carioca ${ }^{119}$ e considerados reacionários e portanto inimigos de Floriano e da República; um autoritarismo manifestado na defesa da ditadura militar encarnada na figura do Marechal Floriano Peixoto; um progressismo que se traduz na defesa da industrialização, de medidas visando melhorar a condição de vida dos trabalhadores; um forte anti-clericalismo ${ }^{120}$.

Embora a designação de Jacobinismo tenha sido escolhida para se fazer uma associação com a facção política de Robespierre, não podemos de forma

\footnotetext{
${ }^{115}$ Suely Robles Reis de Queiroz, p. 241.

${ }^{116}$ Suely Robles Reis de Queiroz, p. 82.

117 Segundo o jornal O Jacobino, em novembro de 1895 seriam 8 no Paraná, 5 em São Paulo, 4 no Estado do Rio de Janeiro, 4 em Minas Gerais, 4 no Pará, 3 no Rio Grande do Sul e 1 no Distrito Federal; este número aumentaria daí para frente, tendo um crescimento mais acelerado em 1897, devido às agitações políticas em torno da Guerra de Canudos (Suely Robles Reis de Queiroz, p. 82).

${ }_{118}$ Suely Robles Reis de Queiroz, p. 234.

119 O jacobinismo elegeu como principal alvo de suas iras os portugueses, considerados usurpadores de empregos e exploradores dos brasileiros através do controle que exerciam sobre grande parte do comércio e das casas de aluguel (José Murilo de Carvalho, Os Bestializados, p. 21).

${ }_{120}$ Para todos esses tópicos da ideologia jacobina, ver o livro de Suely Robles Reis de Queiroz, pp. 88-128.
} 
alguma considerar o jacobinismo brasileiro como uma réplica do modelo francês. Se encontramos semelhanças entre os dois jacobinismos, como o radicalismo republicano, o nacionalismo e a austeridade ${ }^{121}$, por outro lado não encontramos na vertente brasileira questões como o igualitarismo social, a participação popular no poder e a reforma agrária, pilares da matriz francesa ${ }^{122}$. Além do mais, René Rémond (pp. 157-163) distingue bem o nacionalismo universalista da Revolução Francesa e das revoluções libertárias da primeira metade do século XIX, do nacionalismo xenófobo e exclusivista de fins do mesmo século, nacionalismo do qual o jacobinismo brasileiro parece se aproximar: seguindo o lema 0 Brasil para brasileiros! (esta é uma das epígrafes do jornal 0 Jacobino), os jacobinos só permitiam a entrada de brasileiros natos em seus clubes, denunciavam a presença de estrangeiros nos serviços públicos e nas Forças Armadas ${ }^{123}$ e incentivavam atos de violência contra os portugueses, vistos como responsáveis pelos altos preços, pela escravidão, pela prostituição, pelas conspirações anti-republicanas etc. $^{124}$. Logicamente, a xenofobia dos jacobinos cariocas dificilmente poderia ser entendida sem uma análise do contexto social do Rio de Janeiro de fins do século XIX: como afirma José Murilo de Carvalho ${ }^{125}$, de acordo com o censo de 1890 , $30 \%$ da população da cidade era composta de estrangeiros. Desses estrangeiros, 70\%, ou seja, 106 461, eram portugueses. A presença portuguesa era particularmente forte em alguns setores da população. Em 1890 eles compunham $40 \%$ dos artesãos, $51 \%$ dos empregados no comércio e 53\% dos empregados em transportes. Certas profissões eram quase monopólio português. (...) A presença estrangeira era ainda muito forte entre a classe proprietária. Estrangeiros eram, em 1890, cerca de 30\% dos proprietários, banqueiros e capitalistas. (...) Mas o antilusitanismo possuía uma venerável tradição no Rio de Janeiro, remontando à época da independência e da Regência. A queixa mais antiga visava o controle do comércio, tanto no que se referia à propriedade das casas quanto ao favorecimento de portugueses na oferta de empregos. $O$ que o surto de

\footnotetext{
${ }^{121}$ Ver o verbete Jacobinismo (pp. 653-655) do Dicionário de Política de Norberto Bobbio.

${ }^{122}$ Lincoln de Abreu Penna, O Progresso da Ordem, p. 118.

${ }^{123}$ Suely Robles Reis de Queiroz, pp. 99-100.

${ }^{124}$ Suely Robles Reis de Queiroz, pp. 103-104.

${ }^{125}$ Os Bestializados, pp. 79-80.
} 
antilusitanismo do início da República acrescentou foi a queixa contra o controle de prédios de aluguel, especialmente das habitações coletivas, incluídos aí os cortiços. Podemos ver, portanto, que a xenofobia e a lusofobia jacobinas, que indiretamente envolviam o Florianismo, com sua política externa fundamentalmente anti-européia, eram uma questão social antiga no Rio de Janeiro, e só como tal podem ser compreendidas.

\section{D) Características da liderança florianista.}

Após termos feito um balanço, mesmo que superficial, das principais características do Florianismo tanto como governo quanto como movimento, procuraremos agora completar esta caracterização ao tentar definir a liderança florianista. Para tal, não podemos, devido à própria complexidade do fenômeno em questão, ser muito taxativos em nossas afirmações, mas podemos todavia levantar hipóteses, como a possível associação da liderança florianista com o conceito de Democracia Autoritária que tomamos de René Rémond ${ }^{126}$, ou melhor com a inserção do Florianismo dentro do conceito de Cesarismo Progressista, assim definido por Antonio Gramsci (p. 63): o cesarismo exprime uma situação em que as forças em luta se equilibram de modo catastrófico, isto é, equilibram-se de tal forma que a continuação da luta só pode levar à destruição recíproca. Quando a força progressista $A$ luta contra a força reacionária $B$, não só pode ocorrer que $A$ vença $B$ e $B$ vença $A$, mas também pode suceder que nem $A$ nem $B$ vençam, porém se aniquilem mutuamente, e uma terceira força, $C$, intervenha de fora submetendo o que resta de $A$ e de $B$. Mas, continua Gramsci (pp. 63-64), o cesarismo, se exprime sempre a solução "arbitral", confiada a uma

\footnotetext{
${ }^{126}$ René Rémond (p. 74) define desta forma o conceito de Democracia Autoritária: É preciso, portanto, ter presente ao espírito que, no século XIX, continua aberta a alternativa para o regime democrático entre a forma representativa e parlamentar e a forma direta e autoritária. Tanto num caso como no outro, a origem do poder é o consentimento popular; mas, no primeiro caso, o povo soberano delega esse poder a representantes por todo o tempo da legislatura, enquanto que no outro caso ele o confia a um executivo, que está acima das assembléias parlamentares. Existe, assim, um tipo de democracia plebiscitária, antiparlamentar, antiliberal, que associa a autoridade $e$ a base popular, que constitui, a seu modo, uma forma de democracia. O autor, na mesma página, cita, como exemplos de Democracia Autoritária, o regime bonapartista na França e o regime de Bismarck na Alemanha.
} 
grande personalidade, de uma situação histórico-política caracterizada por um equilíbrio de forças de perspectiva histórica, não tem sempre o mesmo significado histórico. Pode haver um cesarismo progressista e um cesarismo reacionário. (...) O cesarismo é progressista quando a sua intervenção ajuda a força progressista a triunfar, mesmo com certos compromissos e medidas que limitam a vitória; é reacionário quando a sua intervenção ajuda a força reacionária a triunfar, também neste caso com determinados compromissos e limitações que têm um valor, um alcance e um significado diversos, opostos aos do caso precedente ${ }^{127}$.

No nosso entender, o Florianismo pode ser considerado como uma manifestação de cunho cesarista por se tratar de um fenômeno que gira em torno do que, como vimos, Gramsci chama de uma grande personalidade (aqui um líder político e militar) que age de forma autoritária colocando-se acima dos partidos $^{128}$, das instituições (inclusive do próprio Exército) e das normas parlamentares: Floriano, por exemplo, deportará congressistas para a Amazônia, ignorando as imunidades parlamentares ${ }^{129}$; isto o levará, por exemplo, a ser apoiado por grupos tradicionalmente excluídos da grande política ${ }^{130}$, como os jacobinos e as massas urbanas cariocas. Além do mais, acreditamos poder

\footnotetext{
${ }^{127}$ Gramsci cita Júlio César e Napoleão I como exemplos de Cesarismo Progressista e Napoleão III e Bismarck como exemplos de Cesarismo Reacionário. No entanto, embora não queiramos entrar na discussão dos exemplos citados, pensamos que a caracterização dos governos de Napoleão III e Bismarck como reacionários é no mínimo discutível, dada a grande contribuição de ambos para a modernização de seus países e para o progresso de sua legislação social (ver Edward McNall Burns, pp. 721-722 e 747-748).

${ }_{128}$ Como veremos no capítulo III, o fato de Floriano se aliar estrategicamente com o Partido Republicano Paulista não fará dele um representante político deste, e o fato do Partido Republicano Federal, de Glicério, conter vários elementos florianistas não fará dele um "partido florianista".

${ }^{129}$ José Maria Bello, pp. 91-92. O mesmo autor, na p. 99, nos fala da famosa lenda segundo a qual Floriano, por ocasião da crise de abril 1892 (crise que veremos no capítulo III e na qual estão inseridas essas deportações) teria dito: se os juízes do Tribunal concederem habeas-corpus aos políticos, eu não sei quem amanhã lhes dará o habeas-corpus de que, por sua vez, necessitarão... Esta afirmação, seja ela verídica ou pura anedota, retrata bem o líder ao mesmo tempo autoritário e democrático que se coloca acima das instituições e da própria legalidade.

${ }^{130} \mathrm{Em}$ tabela da p. 75 do livro Os Bestializados, José Murilo de Carvalho divide a população economicamente ativa do Rio de Janeiro, nos anos de 1890 e 1906, em quatro categorias, isto é classe alta, setores intermediários, operariado e proletariado. Esta última, que o autor citado também chama de lumpem (e que poderíamos também, a nosso ver, chamar de "camada subproletária"), representava, nas duas datas, cerca de $50 \%$ da população economicamente ativa carioca, o que no nosso entender representava por sua vez enorme número de excluídos da grande política assim como uma boa base de apoio para lideranças fortes que se colocassem acima das instituições políticas convencionais (um Bonaparte, por exemplo).
} 
analisar o Florianismo à luz do conceito de Cesarismo Progressista, na medida em que, como veremos nos capítulos seguintes, ele intervirá como terceira força num contexto de luta política entre uma força progressista e outra reacionária, vindo a favorecer, mesmo que indiretamente, a primeira.

Veremos a seguir como este fenômeno político-militar nacionalista, republicano e progressista, que gira em torno de uma liderança de cunho cesarista, insere-se no contexto político de primórdios da república brasileira. 


\section{CAPÍTULO II: O DEODORISMO: PAPEL POLÍTICO E SIGNIFICADO HISTÓRICO}

\section{A) A República e a nova elite.}

Como afirma Fernando Henrique Cardoso (p. 16), nem a República foi uma mera quartelada, nem se tratou "apenas" - como se estas não importassem... - de uma mudança ao nível das instituições, que de monárquicas passaram a republicanas, mas houve, de fato, uma mudança nas bases e nas forças sociais que articulavam o sistema de dominação no Brasil. De fato caía, em 15 de novembro de 1889, a já agonizante ordem monárquica no Brasil. Sendo o Império um Estado escravista ${ }^{1}$, a abolição da escravidão, ocorrida em 13 de maio de 1888 e decretada sob a pressão dos grupos abolicionistas e do Exército ${ }^{2}$, tirava a grande base de apoio do regime ${ }^{3}$, e, portanto, o Império caía sem resistência significativa $^{4}$ um ano e meio depois da Abolição.

Isto nos remete a outra questão, importante para o nosso trabalho, que é o fato da elite outrora escravista do Império não ver mais vantagem na volta do

\footnotetext{
${ }^{1}$ Segundo Décio Saes (A Formação do Estado burguês no Brasil, p. 57), o Estado imperial brasileiro se encaixaria dentro do modelo de Estado escravista moderno. Este seria um Estado representante dos proprietários de escravos e cujo aparelho, assim como seus recursos materiais, se confunde com os membros desta classe. A política deste tipo de Estado visa a conservação do escravismo (repressão às revoltas escravas, medidas contra a escassez de escravos), sua fonte de escravos sendo o tráfico (Décio Saes, A Formação do Estado burguês no Brasil, p. 70).

${ }^{2}$ Ver Décio Saes, A Formação do Estado burguês no Brasil, pp. 178 e 346.

3 José Maria Bello, pp. 11 e 12. A elite proprietária de escravos apoiava o centralismo monárquico, mesmo com todas as suas desvantagens (por exemplo a nomeação dos presidentes de Província pelo poder central passando por cima das aspirações políticas das elites locais), por ser o Estado centralizado a melhor garantia para a manutenção da escravidão em todo o território nacional: esta elite, composta de plantadores escravistas, traficantes de escravos e proprietários de escravos de ganho, temia que a autonomia provincial pudesse resultar em abolição isolada nas províncias onde o escravismo estivesse em declínio, enfraquecendo a posição de defesa da escravidão nas províncias onde ela estivesse com força, e por outro lado ela via no centralismo político uma forma de garantir, após a abolição do trafico negreiro em 1850 por pressão inglesa, o tráfico interprovincial de escravos, das regiões economicamente em declínio para as áreas mais prósperas (Décio Saes, A Formação do Estado burguês no Brasil, p. 170).

${ }^{4}$ Celso Castro (pp. 193-194) e Maria de Lourdes Mônaco Janotti (pp. 17 e 21) falam de revoltas militares isoladas em vários pontos do país contra a República pouco depois da Proclamação, revoltas sempre protagonizadas por praças, mas isto a nosso ver não invalida em nada a tese de que a Monarquia não tinha mais base sólida de apoio e que por isso caiu em um dia.
} 
centralismo monárquico após a Proclamação da República, já que o Estado centralizado não teria mais a sua antiga função e passaria a ser um estorvo para a autonomia política das elites provinciais. Podemos, a título de exemplo da aceitação da República pela elite imperial, colocar aqui duas citações. A primeira é de Paulino José Soares de Sousa, figura influente do Partido Conservador do Império na Província do Rio de Janeiro: Não há quem possa contestar que está de vez firmada, no Brasil, a forma de governo republicana. A transformação fez-se sem regresso possível. E, pois, o que importa hoje é a reorganização política da nação, como a esta aprouver, em sua soberania. Com as instituições aniquiladas a 15 do corrente mês, tiveram de perecer os partidos monárquicos, que delas tiravam a sua razão de ser. Persistem, porém, para entrarem em novos quadros e diversamente afeiçoados, os elementos, que as convicções individuais e os interesses sociais poderão talvez por logo em movimento na constituição definitiva da forma de governo. O Conselheiro José Antônio Saraiva, por sua vez figura importante do Partido Liberal, Senador do Império e ex-presidente do Conselho de Estado, escrevia o seguinte, por ocasião do advento da República: A República é um fato consumado. Devemos adota-la e servi-la lealmente. A imprensa deve dedicar-se a obter a ordem e a liberdade ${ }^{5}$. A elite imperial aceitava portanto a República como fato consumado: A República foi recebida, de início, se não com entusiasmo, pelo menos sem qualquer resistência, não apenas por parte das camadas populares, mas até mesmo pela grande maioria dos homens públicos que compunham os quadros políticos do antigo regime. Sentiam todos eles que a monarquia não tinha raízes no Brasil e, na verdade, durara mais do que devia. $A$ transformação do regime era considerada coisa naturalíssima, com a qual de há muito se devia contar, embora não escondessem alguns a sua surpresa ante a rapidez com que se dera aquela mudança ${ }^{6}$. E se a elite imperial aceitou o novo

\footnotetext{
${ }^{5}$ Para essas e outras citações de líderes políticos do Império que aceitaram a República como fato consumado, ver R. Magalhães Júnior, volume II, pp. 110-111.

${ }^{6}$ R. Magalhães Júnior, volume II, p. 110. Como afirma Maria de Lourdes Mônaco Janotti (pp. 260261), abaladas as bases partidárias tradicionais, era natural que continuasse a política das alianças e dos conchavos eleitorais. Como os republicanos não tinham quadros suficientes para prescindir da influência dos políticos das extintas organizações partidárias, compuseram-se facilmente com os antigos chefes, mormente quando afigurou-se-Ihes a necessidade de frear a democratização do Estado.
} 
regime como fato consumado, dificilmente poderia ela promover um projeto político restaurador; em outras palavras, se a elite imperial vai tentar retomar o poder político após o momento de desorganização que se seguiu à Abolição e à Proclamação, essa tentativa será feita sob a forma republicana. $O$ federalismo poderá ser mais ou menos acentuado dependendo da orientação política de cada grupo que lutará pela hegemonia, mas nenhum deles buscará a volta do centralismo monárquico ${ }^{7}$.

Como afirma José Maria dos Santos ${ }^{8}$, a proclamação da República, nos seus dados imediatos, foi um acontecimento exclusivamente carioca, reduzindo-se a um levante da guarnição do Rio de Janeiro, ali mesmo provocado e ali mesmo resolvido, sem maior ação sobre as províncias, além da simples comunicação de haver-se consumado. De fato, o episódio político que marcou a passagem do Império para a República resultou de uma articulação política entre os republicanos do Rio de Janeiro (Quintino Bocaiúva, Aristides Lobo, Sampaio Ferraz, etc.) e militares que serviam na Corte ou que pelo menos lá se situavam (Benjamin Constant, Sólon Ribeiro, Serzedelo Corrêa e o próprio Deodoro, entre

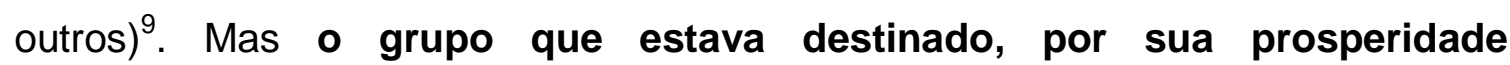
econômica, a se apoderar do aparelho de Estado no novo regime vinha de São Paulo e estava ligado ao café.

Sendo a partir da década de 1830 o principal produto de exportação do país ${ }^{10}$, o café começou a ser produzido nos arredores da cidade do Rio de Janeiro e, em decorrência do desgaste dos solos, se deslocou para o Vale do Paraíba fluminense e depois para o Vale do Paraíba paulista, para se instalar finalmente no interior de São Paulo, nas áreas de Campinas, Rio Claro, Mogi Mirim, Ribeirão

\footnotetext{
${ }^{7}$ O monarquismo romântico de Saldanha da Gama é, como veremos no próximo capítulo, um fator enganoso para o estudo das verdadeiras aspirações do anti-florianismo.

${ }^{8}$ Bernardino de Campos e o Partido Republicano Paulista, Prefácio, p. XI.

${ }^{9}$ Ver José Maria dos Santos, Bernardino de Campos e o Partido Republicano Paulista, capítulo IV, onde é estudado o contexto político da conspiração republicana.

${ }_{10}$ Eduardo Kugelmas, pp. 14-15.
} 
Preto, Araraquara, Jaú e outras ${ }^{11}$. A partir da década de 1870, e mais acentuadamente na de 1880, a ascensão da produção cafeeira no oeste paulista vai contrastar com a decadência da mesma na Província do Rio de Janeiro ${ }^{12}$, isto se dando pelo caráter itinerante da produção cafeeira, já que os cafezais fluminenses, mais antigos, com terras já cansadas e cuja fertilidade se esgotava, apresentavam produtividade em declínio ${ }^{13}$. Portanto, o futuro da economia cafeeira, grande fonte de riqueza do Império, estava em São Paulo.

O surto de crescimento do café paulista começa na década de $1850^{14}$, e este crescimento exige o fortalecimento de um setor de infraestrutura: para a comercialização e o financiamento da crescente produção cafeeira torna-se necessária a existência de um sistema comercial baseado em casas comerciais e rede bancária; a expansão das plantações de café, cada vez mais para longe do porto de Santos, exige por sua vez a expansão das ferrovias; e com a comercialização e o financiamento do café, cidades como São Paulo e Santos vão ocupando uma posição central na economia cafeeira, tornando-se por isso necessária a formação de um setor de serviços urbanos. Nasce a partir daí o grande capital cafeeiro, no qual encontraremos nomes como Silva Prado, Souza Queirós, Vergueiro, Souza Aranha, Pais de Barros, Melo de Oliveira, Pacheco Jordão, Queirós Telles, Dias da Silva, Diedrichsen, Toledo Piza, Ulhôa Cintra e outros, e que consiste num conjunto de grupos ligados ao financiamento e à comercialização da produção cafeeira, bem como às ferrovias e também a um pequeno setor industrial (vidraria, tecidos, calçados, cimento, etc.) ${ }^{15}$. O grande capital cafeeiro e a lavoura constituirão juntos o que chamaremos aqui de elite cafeeira paulista, elite que a partir da década de 1890 estará longe de formar um bloco homogêneo, mas que no período 1850-1890 será marcada pela interdependência entre os dois grupos que a formavam ${ }^{16}$. A elite cafeeira paulista seria, portanto, por seu dinamismo e por seu efeito no desenvolvimento de uma

\footnotetext{
${ }^{11}$ Amaury Patrick Gremaud, p. 45.

${ }^{12}$ Eduardo Kugelmas, pp. 15-16.

${ }^{13}$ Amaury Patrick Gremaud, p. 46.

${ }^{14}$ Eduardo Kugelmas, pp. 15-16.

${ }^{15}$ Para todas essas informações, ver Renato M. Perissinotto, pp. 37-45.

${ }^{16}$ Renato M. Perissionotto, p. 45.
} 
infraestrutura mais moderna, uma força progressista. Logicamente, como se trata de uma classe voltada para o modelo agro-exportador e não para a indústria ${ }^{17}$ e o mercado interno ${ }^{18}$, esse progressismo é apenas relativo.

Entretanto, é justamente quando começa a grande ascensão da economia cafeeira paulista a partir da década de 1870, ascensão que se deve às condições favoráveis do mercado externo ${ }^{19}$, que a elite cafeeira começa a entrar em choque com o Estado imperial. Esta tensão política entre a elite paulista e o centralismo monárquico se deve sobretudo a três fatores: 1) o centralismo monárquico significava todas as fontes de receita nas mãos do Tesouro Nacional (impostos de importação, exportação, transmissão de propriedade, indústrias e profissões, e predial $^{20}$ ), e portanto a maior parte dos lucros da exportação do café nas mãos do governo central, que utilizava os seus recursos orçamentários para favorecer, através da garantia a empréstimos, de isenções alfandegárias, etc., a implantação de engenhos centrais de açúcar, impedindo que os paulistas aplicassem esses lucros no desenvolvimento da rede ferroviária em sua província, além de dificultar o crédito à produção e à exportação de café por negar faculdade emissora a bancos paulistas e de implementar uma política de imigração insuficiente para a cafeicultura, entre outras desvantagens ${ }^{21}$; 2) a nomeação dos presidentes de província pelo governo central impedia a elite paulista de adquirir maior autonomia política e de garantir seus interesses ${ }^{22}$; 3) a pouca representatividade dos paulistas na vida política do Império, com a pequena presença dos políticos da Província de São Paulo no Senado, na Câmara dos Deputados e no Conselho de Estado $^{23}$, destoando da ascensão econômica da região e impedindo que sua elite

\footnotetext{
${ }^{17}$ Embora a origem do desenvolvimento da burguesia industrial brasileira esteja ligada à economia cafeeira, esta imporá limites econômicos e políticos ao avanço daquela ao longo da Primeira República (Renato M. Perissinotto, p.129).

${ }^{18}$ Décio Saes, A Formação do Estado burguês no Brasil, p. 256.

${ }^{19}$ Renato M. Perissinotto, p. 40.

${ }^{20}$ Ver Décio Saes, A Formação do Estado burguês no Brasil, nota da p. 256. Segundo o mesmo autor, no mesmo trecho, sabe-se que as províncias cobravam por contra própria - isto é à margem da lei - alguns tributos (ex: exportação, consumo) já arrecadados pelo governo central. Mas a prática da bitributação não podia ser, para o bloco regional cafeeiro, a melhor opção em matéria tributária; era-lhe antes preferível a transferência legal dos impostos gerais para as províncias.

${ }^{21}$ Décio Saes, A Formação do Estado burguês no Brasil, p. 255.

${ }^{22}$ Renato M. Perissinotto, p. 93.

${ }^{23}$ Renato Perissinotto, pp. 93-94.
} 
tivesse voz mais ativa na política imperial. Conseqüentemente, a descentralização foi se tornando progressivamente a causa da elite paulista, acima e além das divisões partidárias ${ }^{24}$, e já no início da década de 1870 adotou-se a bandeira da Federação, que teria como função romper com o centralismo monárquico sem por em risco a unidade nacional ${ }^{25}$. Mas ao mesmo tempo era impossível a implantação de uma monarquia federativa, ao contrário do que viriam a pensar mais tarde Joaquim Nabuco e Rui Barbosa ${ }^{26}$, já que seria uma contradição a sustentação de ao mesmo tempo um governo dinástico a nível nacional e de um executivo e um legislativo provincial escolhidos pela elite local: a monarquia federativa só poderia ser viável num país onde houvesse dinastias monárquicas provinciais, como era o caso da Alemanha unificada em 1871 (e não o do Brasil) ${ }^{27}$. Portanto, boa parte da elite paulista optará pela República como único meio de se atingir a Federação: em 1872 nasce o Partido Republicano Paulista (PRP), representando as classes dominantes de São Paulo e cuja grande bandeira será a Federação ${ }^{28}$.

Mas por outro lado, sendo a elite cafeeira favorável à manutenção da escravidão, já que no Brasil escravista do século XIX a propriedade escrava era a base de todo o crédito, isto é, a única forma de os plantadores obterem dinheiro de banqueiros, usurários ou exportadores (sendo a terra em grande abundância no país, e portanto sem grande valor econômico, o escravo era a garantia hipotecária) ${ }^{29}$, o PRP vai evitar de tocar na questão, que no entanto era a espinha dorsal do regime: a maior preocupação dos congressistas de 1873 consistiu justamente em se escoimarem de qualquer simpatia pela liberdade dos negros. $O$ que os dominou naquela assembléia foi sobretudo o terror de parecerem suspeitos aos senhores de escravos e de irem ao encontro dos seus próprios interesses de

\footnotetext{
${ }^{24}$ Eduardo Kugelmas, p. 34.

${ }^{25}$ Renato Perissinotto, p. 94.

${ }^{26}$ Ver José Maria Bello, p. 53.

27 Ver Décio Saes, A Formação do Estado burguês no Brasil, p. 257. Para o exemplo da monarquia federativa na Alemanha, ver René Rémond, p. 65.

${ }^{28}$ Renato M. Perissinotto, p. 95.

${ }^{29}$ Décio Saes, A Formação do Estado burguês no Brasil, p. 201.
} 
fazendeiros ${ }^{30}$. É claro que haverá uma minoria abolicionista dentro do partido, uma "minoria radical" representada por líderes como Bernardino de Campos e Luís Gama $^{31}$, mas em seu conjunto o PRP vai se manter no apoio ao escravismo ${ }^{32}$, e portanto o seu peso entre 1873, ano de seu manifesto de fundação, e 1887, quando adere ao abolicionismo vendo o fato consumado ${ }^{33}$, será apenas de grupo de pressão representando os interesses paulistas dentro da política imperial: a partir de 1876 o PRP se lança com sucesso em acordos eleitorais com os partidos monárquicos, e sua bancada reduzida nunca defenderá a abolição e a derrubada violenta da Monarquia ${ }^{34}$.

Já que o PRP era incapaz, pelas razões acima expostas, de mexer no centro nervoso do regime monárquico, isto é a escravidão, será preciso que outros grupos preparem o caminho para sua futura ascensão política: os grupos abolicionistas radicais, representados por líderes como José do Patrocínio, Antônio Bento, Bernardino de Campos e Silva Jardim, ao incentivar a fuga em massa de escravos das fazendas e a formação de quilombos ${ }^{35}$, e o Exército, ao se recusar a perseguir os escravos fugidos ${ }^{36}$, tiram a base de sustento do regime forçando a Princesa Isabel a assinar a Lei Áurea em 13 de maio de 1888; a aliança entre os republicanos cariocas, representados entre outros por Quintino Bocaiúva e Aristides Lobo ${ }^{37}$, e oficiais influentes do Exército (em particular Deodoro e Benjamin Constant) derruba, através de um golpe militar, o Estado

\footnotetext{
${ }^{30}$ José Maria dos Santos, A Política Geral do Brasil, p. 175. O autor citado está se referindo ao primeiro congresso republicano da Província de São Paulo, presidido por Américo Brasiliense e ocorrido em 2 de julho de 1873 na capital paulista (ver obra citada, p. 174).

${ }^{31}$ Décio Saes, A Formação do Estado burguês no Brasil, pp. 307-308.

32 José Maria dos Santos, A Política Geral do Brasil, pp. 174-176.

${ }^{33}$ Décio Saes, A Formação do Estado burguês no Brasil, pp. 262-263.

${ }^{34}$ Décio Saes, A Formação do Estado burguês no Brasil, p. 263. A própria adoção do evolucionismo como meio de se chegar à República,e não a revolução (José Ênio Casalecchi, pp. 53-54), está a nosso ver intrinsecamente ligada a esse temor do rompimento com a ordem escravista.

35 Décio Saes, A Formação do Estado burguês no Brasil, pp. 277-278.

${ }^{36}$ Décio Saes, A Formação do Estado burguês no Brasil, p. 178. Jeanne Berrance de Castro ( $p$. 298) nos fala da reforma de 1873, através da qual a Guarda nacional perdia suas funções internas para ser chamada apenas em caso de perigo externo. A partir desse momento, a função repressiva, em especial a repressão às revoltas escravas, deveria ser feita por outras forças. Como vimos no primeiro capítulo, estando o Exército (em grande parte abolicionista), na década de 1880, incumbido de reprimir as revoltas escravas, tal transferência de funções se revelou um suicídio por parte da elite escravista.

${ }^{37}$ Décio Saes, A Formação do Estado burguês no Brasil, p. 265.
} 
imperial. O caminho estava aberto para o PRP e a elite cafeeira paulista se apoderarem do aparelho de Estado, caminho aberto à sua revelia, já que o PRP, como vimos, era contrário tanto à abolição da escravidão quanto à derrubada pela força do regime monárquico. O resto do caminho, que levará à vitória final do PRP dentro do regime republicano, envolverá o Florianismo, tanto como aliado quanto como adversário dos paulistas.

\section{B) Deodoro.}

Através de um golpe de Estado liderado pelo Marechal Deodoro da Fonseca, era derrubado, em 15 de novembro de 1889, o Gabinete Ouro Preto e com ele a Monarquia. No mesmo dia já era escolhido o primeiro ministério republicano e no dia imediato eram divulgados o manifesto do novo governo e o primeiro decreto constitutivo do novo regime ${ }^{38}$. Neste decreto, redigido por Rui Barbosa, era proclamada provisoriamente a República Federativa, as antigas províncias do Império sendo transformadas em Estados com poder de decretar a sua própria Constituição e de eleger os seus corpos deliberantes e os seus governos $^{39}$. Com a derrubada do regime, eram abolidos o Conselho de Estado e o Senado vitalício, a Câmara dos Deputados era dissolvida ${ }^{40}$, e estabelecia-se uma ditadura provisória sob o nome de Governo Provisório dos Estados Unidos do Brasil $^{41}$, cujo comando cabia naturalmente a Deodoro, a liderança militar que efetivara a derrubada do regime anterior.

O primeiro ministério republicano, pela própria composição, revela seu caráter provisório, já que representa uma coalizão das principais forças republicanas do Brasil: para o Ministério da Guerra, é nomeado o Tenente-Coronel Benjamin Constant Botelho de Magalhães, líder da oficialidade positivista do

\footnotetext{
38 José Maria Bello, p. 33.

${ }^{39}$ Edgard Carone, A Primeira República - texto e contexto, p. 15.

40 José Maria Bello, p. 34.

${ }^{41}$ Edgard Carone, A Primeira República - texto e contexto, p. 15.
} 
Exército; para a pasta da Marinha, o Chefe-de-Divisão ${ }^{42}$ Eduardo Wandenkolk, representando a oficialidade republicana desta corporação; para as pastas do Interior e das Relações Exteriores, são escolhidos respectivamente Aristides Lobo e Quintino Bocaiúva, representantes dos republicanos do Rio de Janeiro; para o Ministério da Agricultura, Comércio e Obras Públicas, Demétrio Ribeiro, representando os republicanos positivistas do Rio Grande do Sul; os republicanos de São Paulo estão representados na pasta da Justiça, com Manuel Ferraz de Campos Sales, uma das principais figuras do PRP; e, finalmente, para a pasta da Fazenda é nomeado o baiano Rui Barbosa, que de certa forma representaria os monarquistas que aderiram à República no último momento, isto é os "republicanos de última hora" ${ }^{43}$. Deodoro é aqui a autoridade militar que simboliza a coalizão republicana, e portanto o Deodorismo enquanto fenômeno político ainda não existe.

O Governo Provisório passará, até janeiro de 1891, por crises ministeriais, como a saída de Demétrio Ribeiro e sua substituição pelo paulista Francisco Glicério $^{44}$, a saída de Aristides Lobo e sua substituição pelo mineiro Cesário Alvim $^{45}$ e a transferência de Benjamin Constant do Ministério da Guerra, onde é substituído por Floriano Peixoto, para o recém-criado Ministério da Instrução Pública, Correios e Telégrafos ${ }^{46}$; mas as crises que colocarão em cheque o poder político de Deodoro envolverão as tensões entre o Chefe do Governo Provisório e os republicanos paulistas, assim como as divisões políticas dentro das Forças Armadas.

Manuel Deodoro da Fonseca era, assim como Floriano Peixoto, oriundo de Alagoas. Vinha de uma família essencialmente militar ${ }^{47}$ : seu pai era oficial do Exército e todos os seus irmãos homens seguiriam a carreira das armas, três

\footnotetext{
${ }^{42} \mathrm{Na}$ República o Chefe-de-Divisão passaria a se chamar Contra-Almirante. Ver Gustavo Barroso, pp. 98 e 99, onde é exposto o quadro hierárquico das forças navais luso-brasileiras e brasileiras na Colônia, no Império e na República.

${ }_{43}^{4}$ Para essa relação de ministros, ver José Maria Bello, pp. 35-38.

${ }^{44}$ José Maria Bello, p. 60.

${ }^{45}$ José Maria Bello, p. 68.

${ }^{46}$ Edgard Carone, A República Velha (Evolução Política), p. 45.

${ }^{47}$ Celso Castro, p. 98.
} 
deles vindo a morrer na Guerra do Paraguai ${ }^{48}$. Nascido em 1827, ingressou na Escola Militar (Rio de Janeiro) em 1843, e em 1845 assentava praça voluntária no $4^{\circ}$ Batalhão de Artilharia a Pé ${ }^{49}$. Como $2^{\circ}$ Tenente de Artilharia participava, em 1849, da repressão à Revolução Praieira em Pernambuco ${ }^{50}$. Já no posto de Capitão, tomava parte na campanha brasileira no Uruguai em 1864-1865; lutou na Guerra do Paraguai (1865-1870), distinguindo-se pela bravura no combate e terminando o conflito com a patente de Corone ${ }^{51}$. Promovido a Brigadeiro em 1874, serviu em diversas regiões do Brasil ${ }^{52}$; à sua promoção a Marechal-deCampo, em 1884, seguiu-se a nomeação para Quartel-Mestre General (cujas funções corresponderiam hoje às da Intendência e da Diretoria do Material Bélico ${ }^{53}$ ) e para o Comando das Armas do Rio Grande do Sul, ambas as nomeações ocorrendo em $1885^{54}$. Da mesma forma que a carreira política de Floriano começava na Província de Mato Grosso, a carreira política de Deodoro se iniciava no Rio Grande do Sul, onde se encontrava a guarnição mais poderosa do país ${ }^{55}$.

Deodoro, até o início da década de 1880, se mantinha como oficial apolítico $^{56}$, e portanto leal à ordem monárquica. A politização de sua carreira militar ocorrerá por insistência de integrantes da própria elite imperial. O Barão de Cotegipe, uma das principais figuras do Partido Conservador e Chefe de Gabinete entre setembro de 1885 e março de 1888, estando à procura de um novo Caxias, isto é de um novo grande general do Partido Conservador, decide atrair Deodoro, um alto oficial em evidente ascensão profissional e que tendia a se transformar numa liderança indiscutível dentro do Exército, para a sua política ${ }^{57}$. É com a subida do Gabinete Cotegipe que Deodoro é nomeado Comandante das Armas da

\footnotetext{
${ }^{48}$ Celso Castro, pp. 99-100.

${ }^{49}$ R. Magalhães Júnior, volume I, p. 23.

${ }^{50}$ R. Magalhães Júnior, volume I, p. 40.

${ }^{51}$ Celso Castro, pp. 99-100.

${ }^{52}$ Celso Castro, p. 100.

${ }^{53}$ R. Magalhães Júnior, volume I, p. 188.

${ }^{54}$ Celso Castro, p. 100.

${ }^{55}$ Celso Castro, p. 100.

${ }^{56}$ R. Magalhães Júnior, volume I, p. 166.

${ }^{57}$ R. Magalhães Júnior, volume I, p. 197.
} 
Província do Rio Grande do Sul ${ }^{58}$. Através da ação persuasiva do Presidente da Província, o pernambucano Henrique Pereira de Lucena (futuro Barão de Lucena), que se tornará amigo pessoal do Marechal, Deodoro acaba por ingressar nas hostes conservadoras e por aceitar o cargo de Vice-Presidente da Província, acumulando com o de Comandante das Armas ${ }^{59}$. Desta forma, o emotivo Deodoro $^{60}$, além de ter amizade pessoal com o próprio Imperador D. Pedro $\|^{61}$, ligava-se à elite política imperial através da amizade com Lucena ${ }^{62}$. Mas, a nosso ver, as relações pessoais de Deodoro com o establishment conservador não são suficientes para explicar as tão famosas afinidades monárquicas do proclamador da República. No primeiro capítulo de nosso trabalho, mencionamos a diferença de mentalidade entre a oficialidade do Exército que iniciara a carreira antes da reforma de 1850 e a oficialidade que a iniciara depois; os primeiros, por terem formação profissional menos sofisticada, seriam politicamente mais conformistas e conservadores, enquanto que os segundos viriam a exigir mais do Estado imperial, colocando-se progressivamente contra a Monarquia. Deodoro, por ter entrado para o Exército na década de 1840 e por estar sentimentalmente ligado à ordem monárquica, seria um exemplo típico do oficial mais conservador, incapaz de ver o entrave que era a sociedade agrária e escravista do Império para a constituição de Forças Armadas à altura da missão de proteger um território continental como o brasileiro.

No entanto, para desgraça de Cotegipe e de seus correligionários, a Questão Militar tinha no Rio Grande do Sul, assim como no Rio de Janeiro, o seu grande cenário. No ano de 1886, o Tenente-Coronel Antônio de Sena Madureira, Comandante da Escola de Artilharia de Rio Pardo, no Rio Grande do Sul, e já conhecido por suas posições abolicionistas, entrava, através da imprensa, em polêmica com o Senador Franco de Sá, que quando Ministro da Guerra em 1884 o demitira do posto de Comandante da Escola de Tiro de Campo Grande, no Rio de

\footnotetext{
${ }^{58}$ R. Magalhães Júnior, volume I, p. 195.

${ }^{59}$ R. Magalhães Júnior, volume I, pp. 195-196.

${ }^{60}$ José Maria Bello, p. 35.

${ }^{61}$ José Maria Bello, p. 4.

${ }^{62}$ Deodoro e sua esposa chegam até a servir de padrinhos no batizado de um filho de Lucena (R. Magalhães Júnior, volume I, p. 197).
} 
Janeiro, por este oficial ter homenageado o jangadeiro abolicionista cearense Francisco do Nascimento ${ }^{63}$. Sena Madureira conseguira espaço no jornal A Federação, do jornalista republicano e abolcionista Júlio de Castilhos ${ }^{64}$, para se expressar. Estando Deodoro exercendo interinamente a Presidência da Província devido à ausência temporária de Lucena, o Marechal, mesmo contra os seus princípios ideológicos, irá tomar a defesa do oficial que segundo as autoridades imperiais estaria atentando contra a disciplina militar ${ }^{65}$. A partir daí, Deodoro entrará cada vez mais em atrito com o Gabinete Cotegipe, e sobretudo com seu Ministro da Guerra, Alfredo Chaves, resultando na sua demissão do Comando das Armas do Rio Grande do Sul em dezembro do mesmo $a^{66}$ e sua crescente politização contra o establishment imperial. Aí vem a pergunta: por que Deodoro, monarquista e conservador por convicção ideológica, vai se por à frente dos militares rebeldes na luta contra os sucessivos gabinetes imperiais do final da década de 1880? A nosso ver isto se deve pelo fato do velho general se identificar com o Partido Fardado ${ }^{67}$. Deodoro, consciente de seu renome como oficial do Exército, sempre vai oscilar entre a fidelidade à ordem monárquica, à qual estava sentimentalmente ligado, e a posição de liderança dentro de sua corporação.

${ }^{63}$ Celso Castro, pp. 86-87.

${ }^{64}$ Celso Castro, p. 87.

${ }^{65}$ Celso Castro, p. 87.

${ }^{66}$ R. Magalhães Júnior, volume I, p. 236.

${ }^{67}$ Segundo Oliveiros S. Ferreira (p. 43), o Partido Fardado não designaria uma facção política no sentido em que se fala de um partido que se constitua no mundo civil para disputar eleições, e nem um grupo organizado que permanece no tempo como organização; sua existência se evidenciaria em momentos de tensão interna na corporação ou de desencontro dos militares com o Governo. Para que seja possível a existência desse agrupamento momentâneo de militares que se julgam no direito de interpretar o que sejam a lei e a ordem, seria necessária a presença de um centro que exerça função aglutinadora, mesmo que esse centro se resuma a uma só pessoa. A formação do Partido Fardado correspondendo a um momento de crise na sociedade e na vida política do país, o centro aglutinador não teria autoridade sobre os seus seguidores, chegando a se dissolver uma vez resolvida a questão que originou o ajuntamento militar (p. 44). A Questão Militar (ver mesma obra, capítulo XI) seria um exemplo típico de ação política do Partido Fardado. Sendo a rigor uma sucessão de atos de indisciplina formalmente caracterizados como tais pelas autoridades civis, mas no fundo uma exteriorização da insatisfação da classe militar para com a ordem escravista do Império, sua dimensão política vai emergir em virtude do apoio do corpo de oficiais, sobretudo de grandes nomes como Deodoro e Pelotas, este último um dos últimos generais famosos da Guerra do Paraguai ainda vivos, mesmo os dois sendo monarquistas, o primeiro ligado ao Partido Conservador e o segundo ao Partido Liberal. Deodoro e Pelotas formariam o centro aglutinador em torno do qual se uniu a oficialidade progressista do Exército (Sena Madureira, Benjamin Constant, Cunha Matos, etc.), da mesma forma em que nas revoltas tenentistas de 1922 e 1924 os totens do Exército escolhidos pelos revoltosos seriam respectivamente o Marechal Hermes da Fonseca e o General Isidoro Dias Lopes. 
Como afirma R. Magalhães Júnior ${ }^{68}$, Deodoro, homem de rara bravura pessoal, capaz de expor-se com o maior destemor às mais perigosas situações, aliando a mais intransigente honestidade à total despreocupação pelos bens materiais, era marcial, autoritário, cioso de suas prerrogativas, dotado de um temperamento narcisista, que o levava por vezes a atitudes de arrebatamento e obstinação. $O$ mesmo autor afirma mais adiante ${ }^{69}$ : A psicologia de Deodoro era a de um autoritário e de um narcisista. O fundo de narcisismo, tão característico de sua personalidade, foi que o levou a assumir a posição que Ihe era oferecida, contra tudo quanto outrora havia pregado. Devido ao seu temperamento narcisista, Deodoro não admitirá perder sua posição de liderança dentro do Exército, e, mesmo tendendo a ser fiel à ordem monárquica, ele deverá radicalizar seu discurso e sua ação política para não perder o apoio da oficialidade descontente, cujo peso político crescia. Em suma, Deodoro vai radicalizar politicamente para agradar o progressismo militar, que por sua vez tinha que se apoiar num grande nome para transformar seus atos de rebeldia em questão política.

Embora decididamente não fosse republicano ${ }^{70}$, Deodoro vai acabar por se colocar à frente da oficialidade republicana, da mesma forma que se colocara à frente da oficialidade rebelde na Questão Militar. Mas, mesmo que fosse narcisista, sua bravura não pode ser ignorada, sua bravura tanto nos campos de batalha quanto dentro da arena política: por exemplo, enquanto Presidente do Clube Militar, Deodoro assinarará o manifesto da entidade, em outubro de 1887, através do qual o Exército se recusava a cumprir a tarefa de perseguir os escravos que fugiam em massa das fazendas ${ }^{71}$, responsabilizando-se por um ato de franca rebeldia de sua corporação frente à ordem escravista do Império. Deodoro cumprirá o papel histórico de derrubar a já agonizante ordem monárquica através de sua ação intempestiva, essencial naquele momento de crise final do Império:

\footnotetext{
${ }^{68}$ Volume I, pp. 7 e 8.

${ }^{69}$ Volume II, p. 29.

${ }^{70} \mathrm{Em} 30$ de setembro de 1888, em carta a seu sobrinho Clodoaldo, aluno da Escola Militar e republicano, Deodoro dizia o seguinte: República, no Brasil, é coisa impossível, porque será verdadeira desgraça. Quem quer República, quer que o Brasil seja dos Gaspares, Cotegipe, Paulino de Sousa, etc. Os brasileiros estão e estarão muito mal educados para "republicanos"; o único sustentáculo do nosso Brasil é a monarquia; se mal com ela, pior sem ela (R. Magalhães Júnior, volume I, p. 333).

${ }^{71}$ R. Magalhães Júnior, volume I, pp. 317 e 318.
} 
Deodoro da Fonseca, eis, em verdade, na hora decisiva, a grande figura central da vitória republicana. A sua impulsiva coragem libertou o Brasil de um regime político superado e pouco estimulante das energias realizadoras ${ }^{72}$. Se os verdadeiros mentores da conspiração republicana no seio das Forças Armadas foram oficiais como Benjamin Constant e Sólon Ribeiro, a presença de Deodoro, oficial de grande prestígio dentro do Exército $^{73}$, foi vital por ser ele o centro aglutinador dos militares descontentes. Não fosse isso, talvez a degenerescência da elite imperial pudesse a longo prazo dar origem a uma solução política mais violenta: As revoluções acontecem porque, seja pelo afrouxamento da circulação da classe eleita, seja por outra causa, se acumulam nos estratos superiores elementos decadentes que não têm mais os resíduos aptos a mantê-los no poder, que evitam o uso da força, enquanto que aumentam nos estratos inferiores os elementos aptos ao exercício do governo, que estão dispostos a utilizar a força ${ }^{74}$. Em suma, tanto no caso de Deodoro, como no de Floriano, a espada será o motor da evolução histórica do Brasil.

\section{C) O caráter neo-monárquico do Governo Deodoro.}

Dissemos neste capítulo que se a antiga elite imperial fosse, no período posterior à Proclamação da República, procurar retomar o controle do aparelho de Estado, isto se daria sob a forma republicana. As atitudes políticas do Presidente Deodoro e de seus verdadeiros aliados serão a primeira tentativa neste sentido, e por isso chamaremos o Governo Deodoro de neomonárquico, isto é um governo representante de grupos da antiga elite imperial só que respeitando a nova forma de governo. O Marechal, cuja participação e liderança foram fundamentais na queda da Monarquia, deveria ter tido a função, depois do 15 de novembro de 1889, de exercer a função do ditador que garante a ordem pública enquanto são elaboradas a Constituição e preparadas as bases do novo regime. No entanto, o conservadorismo de Deodoro,

\footnotetext{
72 José Maria Bello, p. 24.

73 José Maria Bello, p. 28.

${ }^{74}$ Vilfredo Pareto (ver José Albertino Rodrigues, p. 82).
} 
se fora relegado a um segundo plano durante a Questão Militar e a conspiração republicana, voltaria à tona com seu governo na República.

Nos primeiros meses do Governo Provisório, Deodoro se opõe sem sucesso aos decretos de seu Ministro da Justiça, Campos Sales, estabelecendo a dupla soberania na Justiça (um poder judiciário federal e outro estadual) ${ }^{75}$ e 0 casamento civil $^{76}$; Deodoro, aparentemente ainda adepto do centralismo dos tempos do Império e contrário ao Estado laico, entra em choque com o grupo republicano mais poderoso. Mas, o primeiro grande atrito entre o Marechal e os republicanos de todos os matizes envolverá a figura de Rui Barbosa ${ }^{77}$.

Tendo tomado o partido de Deodoro e dos militares contra o gabinete conservador Cotegipe, na época da Questão Militar, assim como contra o Visconde de Ouro Preto $^{78}$, Rui Barbosa exercia grande influência sobre 0 Marechal, a ponto deste nomeá-lo $1^{\circ}$ Vice-Chefe do Governo Provisório ${ }^{79}$. Como diz o positivista Teixeira Mendes ${ }^{80}$, no posto a que o elevaram as nossas

\footnotetext{
${ }_{75}^{75}$ Edgard Carone, A República Velha (Evolução Política), p.30.

${ }^{76}$ Edgard Carone, A República Velha (Evolução Política), p. 29. Como observa Eduardo Kugelmas (pp. 48-49), decretos como o da separação de Igreja e Estado e do casamento civil, além de coincidirem com o ideário laico dos republicanos, visavam a integração da população nãocatólica no intuito de tornar o Brasil um país mais atraente para a vinda de imigrantes para a lavoura; o decreto estabelecendo a dupla soberania na Justiça era por sua vez um ponto fundamental para a viabilização da Federação. Podemos ver, portanto, que a ação do PRP, através de Campos Sales, dentro do Governo Provisório será de contribuir para a implantação de reformas que beneficiem, direta ou indiretamente, a economia cafeeira de São Paulo.

${ }^{77}$ Rui Barbosa, assim como Joaquim Nabuco, seria um exemplo típico de monarquista do Partido Liberal que na década de 1880 pedia reformas que adaptassem o regime imperial às novas exigências sociais, e que por isso se tornara abolicionista e defensore de uma monarquia federativa (José Maria Bello, pp. 24 e 43). No entanto, ao contrário de Nabuco, Rui Barbosa, muito provavelmente percebendo a contradição entre adotar reformas como a Abolição e a Federação e manter o Estado imperial, passou, em 1889, a atacar, através de suas atividades jornalísticas, o ministério de seu correligionário do Partido Liberal, o Visconde de Ouro Preto, e em novembro do mesmo ano já fazia parte da conspiração republicana, tornando-se defensor da República Federativa e Presidencial segundo os moldes norte-americanos (ver José Maria Bello, pp. 28, 30 e 36). Rui diria mais tarde, para justificar sua transformação de monarquista em republicano: Eu era federalista antes de ser republicano. Não me fiz republicano senão quando a exigência irrefragável me convenceu de que a Monarquia se incrustara irredutivelmente na resistência à federação (Hélio Silva, p. 104).

${ }^{78}$ Ver R. Magalhães Júnior, volume I, p. 241 e volume II, p. 31.

${ }^{79}$ R. Magalhães Júnior, volume II, pp. 120-121.

${ }^{80}$ Citado por José Maria dos Santos, Bernardino de Campos e o Partido Republicano Paulista, p. 129.
} 
fatalidades históricas, ele $e^{81}$ tem continuamente patenteado que não assimilou de fato as disposições republicanas. A sua atitude no-lo mostra como simples representante do regime transato procurando calcar a nova situação nos moldes do Império em vez de afeiçoar-se à moderna organização política de nossa pátria; poderíamos interpretar esta afirmação como uma "denúncia" da fidelidade ideológica de Deodoro ao parlamentarismo monárquico, já que, se formos examinar cuidadosamente a organização do Governo Provisório, veremos que Rui Barbosa, que executará sua política financeira com o beneplácito do Marechal mesmo com a oposição dos outros ministros, está na posição confortável de Chefe de Gabinete, enquanto que Deodoro se coloca no lugar do antigo Poder Moderador, com a finalidade de intervir para garantir o funcionamento ordeiro do sistema parlamentar. O ex-monarquista Deodoro coloca o ex-monarquista Rui Barbosa numa posição privilegiada em relação aos outros ministros, nomeando-o $1^{\circ}$ Vice-Chefe do Governo Provisório e dando-Ihe carta branca para fazer uma política impopular entre os seus colegas.

Através do decreto de 17 de janeiro de 1890, de autoria de Rui e assinado por Deodoro à revelia dos outros ministros ${ }^{82}$, é posta em prática uma política emissionista que dava seqüência, embora de forma mais acentuada, à política financeira do Gabinete Ouro Preto. Esta política visava, entre outras coisas, a indenização aos antigos proprietários de escravos ${ }^{83}$ e dinamizar o meio circulante, já que a tradicional falta de dinheiro devida à rígida política imperial de controle de sua oferta se agravara com a libertação dos escravos ${ }^{84}$. Os grandes beneficiados dessa política de Ouro Preto foram os bancos, sendo o grande banco emissor da época o Banco Nacional do Brasil, pertencente ao Visconde de Figueiredo ${ }^{85}$. Rui Barbosa, aliado da burguesia bancária do Rio de Janeiro, em especial do grande

\footnotetext{
${ }^{81}$ Teixeira Mendes está se referindo a Deodoro.

${ }^{82}$ Edgard Carone, A República Velha (Evolução Política), p. 28.

${ }^{83}$ Decio Saes, A Formação do Estado burguês no Brasil, p. 340.

${ }^{84}$ Renato M. Perissinotto, pp. 55-56. Dissemos mais atrás que a propriedade do escravo era a base de todo o crédito, e portanto o desaparecimento do escravo significou a perda de valor dos títulos de propriedade acumulados pelos bancos em troca dos empréstimos aos proprietários de escravos.

${ }^{85}$ Renato M. Perissinotto, p. 56.
} 
banqueiro e Conselheiro do Império Francisco de Paula Mayrink ${ }^{86}$, vai dar continuidade a essa política, indo além dela ao autorizar a organização de bancos de emissão com base nos títulos da dívida pública ${ }^{87}$. Esta política financeira, como é sabido, vai dar origem ao Encilhamento, um período de intensa especulação financeira (empresas fictícias) e grande inflação.

Embora a política inflacionista de Rui Barbosa tenha de certa forma beneficiado a lavoura cafeeira, não somente devido à indenização pela perda dos escravos mas também pela facilidade de crédito, o grande capital cafeeiro, seu sócio mais poderoso, sairá prejudicado: o setor ferroviário, uma de suas principais atividades, terá dificuldades devido ao encarecimento das importações, de onde ele tirava seus principais meios de produção, ao encarecimento dos juros e das amortizações dos empréstimos externos contraídos pelas ferrovias e às pressões para o aumento dos salários ${ }^{88}$. $E$ isto fará com que a elite cafeeira paulista, vanguarda econômica do país, se coloque progressivamente contra o Governo Deodoro. Durante a fase da Assembléia Constituinte (15 de novembro de 1890 a 24 de fevereiro de 1891), a oposição do PRP a Deodoro vai se caracterizar pela ação política de Prudente de Moraes, outra figura importante deste partido e eleito Presidente da Constituinte ${ }^{89}$. Devido ao peso político dos paulistas, a oposição ao Marechal dentro do Congresso Constituinte vai reunir os mais capazes e melhores elementos da Assembléia ${ }^{90}$, dentre eles Demétrio Ribeiro, Francisco Glicério e os militares José Simeão de Oliveira e Custódio de Melo ${ }^{91}$. A oposição crescente entre o governo neo-monárquico de Deodoro e o PRP e seus aliados vai

\footnotetext{
${ }^{86}$ Uma parte da historiografia brasileira (ver Nelson Werneck Sodré, p. 164, e História Nova do Brasil, pp. 109-116) vê Rui Barbosa como um representante dos interesses da indústria nacional contra o latifúndio. Não compartilhamos desta visão, já que, embora a indústria tenha de certa forma se beneficiado da política inflacionista do Ministro da Fazenda pelo fato da inflação encarecer os produtos importados, fornecer crédito fácil, liquidez e disponibilidade de recursos, esse efeito positivo foi apenas indireto, porque o público-alvo de Rui era a sobretudo burguesia bancária do Rio de Janeiro (Renato M. Perissinotto, p. 58). Por outro lado, notemos que sendo o Brasil um país carente de um setor produtor de bens de capital (Renato M. Perissinotto, p. 54), a própria indústria brasileira sairia prejudicada de uma política inflacionista que encarecesse o preço da maquinaria estrangeira, da qual ela precisava.

${ }^{87}$ Renato M. Perissinotto, p. 56.

${ }^{88}$ Renato M. Perissinotto, pp. 57-58.

${ }^{89}$ José Maria dos Santos, Bernardino de Campos e o Partido Republicano Paulista, p. 194.

${ }^{90}$ José Maria dos Santos, Bernardino de Campos e o Partido Republicano Paulista, p. 194.

${ }^{91}$ José Maria Bello, p. 75.
} 
desembocar em duas grandes crises ministeriais originárias de episódios que em si não justificariam o pedido de demissão coletiva de um ministério, mas que serviam de pretexto para a exteriorização da insatisfação das diversas tendências republicanas em relação à política do Chefe de Estado. O primeiro pedido, recusado pelo Chefe do Governo, ocorre em novembro de 1890 devido ao ataque, por militares deodoristas, ao jornal monarquista A Tribuna, onde os artigos de Eduardo Prado procuravam denegrir a imagem do Marechal $^{92}$, ataque onde morre um revisor do jornal ${ }^{93}$. O segundo pedido, desta vez aceito pelo Marechal, ocorre em 20 de janeiro de 1891, por ocasião da concessão, por parte de Deodoro a uma empresa de engenheiros amigos seus, para a construção do Porto das Torres no Rio Grande do Sul, concessão feita à revelia de todos os ministros ${ }^{94}$. A demissão coletiva do ministério, concedida pelo governo no dia seguinte ${ }^{95}$, marca o fim da coalizão republicana no poder e o início efetivo do Deodorismo enquanto fenômeno político.

\section{D) $O$ Deodorismo.}

Com a renúncia do primeiro ministério do Governo Provisório sobe ao poder um novo formado pelo monarquista Barão de Lucena $^{96}$, amigo pessoal de Deodoro e seu antigo correligionário do Partido Conservador. Este ministério será conhecido como o ministério dos áulicos, por nele estar presente apenas um republicano legítimo, Justo Leite Chermont, Ministro do Exterior ${ }^{97}$. Lucena, que

\footnotetext{
${ }^{92}$ Embora consideremos o governo de Deodoro como neo-monárquico, o Marechal era visto de forma negativa por esse periódico que, sem o pé na realidade, assumia abertamente posições em favor da Restauração do Trono e por isso não podia ver com bons olhos o Proclamador da República (ver R. Magalhães Júnior, volume II, p. 239). Sobre a debilidade do movimento monarquista no Brasil pós-1889, assim escreve Maria de Lourdes Mônaco Janotti: além da fraqueza doutrinária, o movimento monarquista demonstrou pequeno poder de atração, girando sempre em torno de círculos políticos e militares, e dirigindo sua propaganda em termos cujo conteúdo só era assimilável por uma reduzida parcela do público. Nem sequer se preocupou com averiguar se subsistia um monarquismo popular: saído da classe dominante, dirigiu-se principalmente a ela própria.

${ }_{93}$ Para maiores detalhes sobre o episódio, ver Maria de Lourdes Mônaco Janotti, pp. 37-39.

${ }^{94}$ Para maiores detalhes ver R. Magalhães Júnior, volume II, pp. 263-269.

${ }^{95}$ R, Magalhães Júnior, volume II, p. 270.

${ }^{96}$ José Maria Bello, p. 77.

${ }^{97}$ José Maria Bello, p. 77.
} 
passa a ocupar a pasta da Agricultura e interinamente a da Justiça, se torna o novo ministro preferido do Marechal, em substituição a Rui Barbosa. Este, embora um ex-monarquista como Deodoro, representava a ala reformista da política imperial, pregando o Abolicionismo e a Federação, e no Governo Provisório fora o autor, junto com Demétrio Ribeiro, do projeto de separação de Igreja e Estado, que Campos Sales transformara em decreto ${ }^{98}$. Desta forma, se por um lado Rui era um ex-monarquista comprometido com a plutocracia financeira do Império, por outro ele não seria o aliado ideal de Deodoro por seu lado relativamente progressista; Lucena, monarquista conservador, estaria muito mais afinado com o Marechal.

O novo "primeiro-ministro" de Deodoro, além de representar a velha elite política do Império, é, assim como Rui Barbosa, um aliado dos grupos financeiros e especuladores do Rio de Janeiro ${ }^{99}$; portanto, ele dará seqüência à política econômica de Rui ${ }^{100}$. Politicamente, Lucena estará, no entanto, mais de acordo com as aspirações centralistas do Marechal. Após aprovada a constituição republicana, de cunho liberal-federalista, a 24 de fevereiro de $1891^{101}$, e após eleito Deodoro Presidente da República pelo Congresso Constituinte no dia seguinte ${ }^{102}$, o Governo Deodoro/Lucena inicia uma política de intervenções federais para remover seus adversários políticos do comando dos Estados de São Paulo e Minas Gerais, dois estados de peso na oposição ao Deodorismo: em São Paulo, o Governador Jorge Tibiriçá, um dos notáveis do PRP, é afastado por

\footnotetext{
${ }^{98}$ Edgard Carone, A República Velha (Evolução Política), p. 29.

${ }^{99}$ Renato M. Perissinotto, p. 59.

${ }^{100}$ Renato M. Perissinotto, p. 59 .

${ }^{101}$ Com o texto constitucional de 1891, elaborado por uma comissão de cinco juristas, muitas das reformas exigidas pelo PRP e decretadas por Campos Sales na pasta da Justiça eram consolidadas: estabelecia-se, entre outras coisas, a República Federativa e Presidencial, a separação de Igreja e Estado e a igualdade jurídica entre os indivíduos. Se a União ficava com o imposto sobre a importação de procedência estrangeira, os estados ficavam com o imposto sobre a exportação de suas próprias mercadorias, e a proibição do voto ao analfabeto se tornaria uma importante arma de defesa da república oligárquica (para a leitura integral da Constituição de $\mathbf{2 4}$ de fevereiro, ver Fernando H. Mendes de Almeida, pp. 101-161).

102 Deodoro era eleito Presidente da República pelo Congresso Constituinte, derrotando Prudente de Moraes; no entanto, seu companheiro de chapa, o Vice-Almirante Eduardo Wandenkolk, era derrotado pelo Marechal Floriano Peixoto, companheiro de chapa de Prudente, na eleição para Vice-Presidente. O silêncio do Congresso em relação a Deodoro e sua ovação a Floriano era uma visível provocação por parte do PRP e seus aliados (para mais detalhes ver José Maria Bello, pp. 75-76).
} 
decreto federal de 6 de março de 1891 e substituído por Américo Brasiliense ${ }^{103}$, um dissidente do republicanismo paulista que, ao contrário da maioria dos republicanos, defendia o centralismo e o parlamentarismo ${ }^{104}$; em Minas, Bias Fortes é derrubado e substituído por Cesário Alvim, levando a maior bancada estadual no Congresso à oposição ao Governo Federal ${ }^{105}$.

Antes de prosseguirmos na descrição da evolução dos fatos históricos, seria necessário definirmos o Deodorismo enquanto fenômeno político, já que é devido a seu fracasso político que nascerá o Florianismo.

O Deodorismo nasce, a nosso ver, com a ascensão do Ministério Lucena, que dá um acabamento completo à política do Marechal. Ele pode ser considerado, assim como o Florianismo, um fenômeno político-militar, não somente por ser Deodoro um grande nome dentro do Exército, mas também pelo fato de ter, entre seus seguidores, diversos militares, como José Clarindo de Queiroz, Saldanha da Gama, Mena Barreto, Taumaturgo de Azevedo, Hermes da Fonseca, entre outros ${ }^{106}$. Mas, por outro lado, ele não seria uma expressão política das Forças Armadas, mas sim de um militar que, ao contrário dos seus colegas de farda mais jovens, estava identificado com a ordem monárquica. Se no final da década de 1880 Deodoro se colocara à frente do Partido Fardado em sua rebeldia contra a ordem imperial, depois de proclamada a República ele não somente se livraria do Partido Fardado como procuraria reprimir sua participação política. Desta forma, ele entrará em atrito com Benjamin Constant e Sólon Ribeiro, dois integrantes da força insurrecional de 15 de novembro, por querer submeter os militares ao poder político ${ }^{107}$. Naturalmente, por ser um oficial de renome, Deodoro terá seguidores militares, mas ideologicamente de forma alguma ele representaria a oficialidade descontente que se rebelou contra a ordem

\footnotetext{
${ }^{103}$ Edgard Carone, A República Velha (Evolução Política), p. 54.

${ }^{104}$ R. Magalhães Júnior, volume II, p. 208.

${ }^{105}$ Edgard Carone, A República Velha (Evolução Política), p. 54.

${ }^{106}$ Esses nomes aparecerão no próximo capítulo, no estudo do contexto das revoltas deodoristas contra o governo de Floriano Peixoto.

${ }^{107}$ Ver R. Magalhães Júnior, volume II, pp. 193-195.
} 
imperial na década de 1880, e sim uma oficialidade que estava em vias de desaparecer devido a seu apego a um regime já superado.

Vimos no primeiro capítulo, ao abordarmos o conceito de Cesarismo, que este representa uma liderança forte que intervém no confronto entre uma força progressista e outra reacionária, e que pode haver um Cesarismo Progressista e um Cesarismo Reacionário dependendo de que lado essa terceira força tende a favorecer. O Deodorismo, por designar um fenômeno político que gira em torno de uma liderança militar forte apoiada na antiga elite monárquica, representada aqui pelo Barão de Lucena, e por promover uma política econômica favorável aos interesses da plutocracia financeira do Império (burguesia bancária do Rio de Janeiro), se encaixa perfeitamente no conceito de Cesarismo Reacionário. Da mesma forma que Floriano, Deodoro, ao procurar submeter os militares ao poder político, se colocaria acima de sua classe, e o fato de ter diversos colegas de farda como seguidores não o impedirá de atrair, por causa de seu conservadorismo, a oposição de um número cada vez maior dentre eles, sendo inclusive derrubado por uma conspiração militar.

\section{E) O Golpe de Estado de 3 de novembro e a queda do Deodorismo.}

Devido à oposição decidida do Congresso à intensificação da política emissionista do Barão de Lucena, assim como à aprovação, por parte deste mesmo Congresso, de uma lei destinada a limitar os poderes do Presidente da República, no dia 3 de novembro de 1891 Deodoro coloca forças militares para cercarem os edifícios do Senado e da Câmara dos Deputados ${ }^{108}$, dissolve os dois e declara instalada a ditadura ${ }^{109}$ : é o chamado golpe da bolsa ${ }^{110}$, através do qual a plutocracia financeira do Império e os seus aliados especuladores que se beneficiaram do Encilhamento procuram se livrar da oposição incômoda do Congresso, que contava com forte presença do PRP (Prudente de Moraes exercia

\footnotetext{
108 José Maria Bello, p. 79.

109 John Schulz, O Exército na Política, p. 170.

110 John Schulz, O Exército na Política, p. 170.
} 
a Presidência do Senado e Bernardino de Campos a da Câmara dos Deputados ${ }^{111}$ ).

No manifesto em que justifica o golpe de Estado, Deodoro fala da animosidade do Congresso para com seu governo, animosidade que se devia à pretensão desse mesmo Congresso em tomar para si funções do Poder Executivo e que se traduzia na sabotagem ao se governo e sobretudo à sua benemérita política emissionista ${ }^{112}$. Em declarações feitas à imprensa, o Marechal afirma pretender "corrigir" a Constituição de 24 de fevereiro, visando, entre outras coisas, fortalecer o Poder Executivo da União em detrimento da autonomia dos Estados, abolir a dualidade de juízes, proibir a eleição de militares da ativa e diminuir o número de deputados ${ }^{113}$; embora em seu manifesto o Marechal denuncie a existência de grupos restauradores ${ }^{114}$, podemos caracterizar a reforma que ele pretende fazer na Constituição como neo-monárquica, já que nela encontramos pontos que se aproximam da organização política do Império, como uma maior centralização político-administrativa (mesmo que dentro dos limites da República Federativa) e a submissão dos militares ao poder político, essa reforma andando de mãos dadas com uma política econômica favorável à plutocracia financeira do Império.

Entretanto, a ditadura Deodoro/Lucena não possuía bases sólidas o suficiente para fazer face à enorme legião de adversários. Além de sofrer a oposição do PRP e de seus aliados, Deodoro foi perdendo gradualmente o apoio dos militares, decepcionados com a orientação política de seus dois anos de governo $^{115}$. Como vimos no primeiro capítulo, desde a década de 1850 havia oficiais insatisfeitos com a ordem monárquica e com o tempo essa insatisfação só veio a aumentar devido à incapacidade do Estado imperial escravista em construir uma estrutura militar digna de defender um grande território como o brasileiro. A Questão Militar envolvera não somente oficiais do Exército como também da

\footnotetext{
${ }^{111}$ R. Magalhães Júnior, volume II, p. 356.

${ }^{112}$ Ver Edgard Carone, A Primeira República (1889-1930) - Texto e Contexto, pp. 17-22.

${ }^{113}$ Edgard Carone, A República Velha (Evolução Política), p. 64.

114 Edgard Carone, A Primeira República (1889-1930) - Texto e Contexto, p. 19.

${ }^{115}$ Edgard Carone, A República Velha (Evolução Política), pp. 58-59.
} 
Marinha $^{116}$, e portanto a insatisfação com a elite imperial era presente nos dois ramos das Forças Armadas. Deodoro e seus aliados, ao procurarem dar seqüência à política imperial pós-escravista (política emissionista visando indenizar os proprietários de escravos e aumentar o fraco meio circulante), isto é ir em auxílio dos grupos sociais que mais foram prejudicados pela Abolição, traíam a classe militar que vira no Marechal o líder que deveria tomar para si as reivindicações do progressismo militar. Diversos oficiais se colocam na oposição ao Deodorismo: no Exército encontramos Floriano Peixoto (Vice-Presidente da República), José Simeão de Oliveira, Pires Ferreira, Sólon Ribeiro, Moreira César, Cunha Matos, além dos militares positivistas seguidores de Benjamin Constant (Barbosa Lima, Lauro Sodré ${ }^{117}$, Serzedelo Corrêa); na Marinha encontramos Custódio José de Melo (que já era oposicionista de Deodoro como deputado na Assembléia Constituinte) e Eduardo Wandenkolk (companheiro de chapa do Marechal na eleição presidencial de 25 de fevereiro), entre outros ${ }^{118}$. Até o Ministro da Guerra de Deodoro, o General Falcão da Frota, teria acobertado as atividades políticas de Floriano (críticas veladas ao governo e tentativas de minar os quartéis) que aglutinavam considerável número de oficiais nas hostes antideodoristas durante o Ministério Lucena ${ }^{119}$. Na Marinha, o único grande nome que fica ao lado do governo é o do Almirante Saldanha da Gama ${ }^{120}$, oficial assumidamente monarquista e que durante o curto período ditatorial será nomeado Chefe do Estado-Maior da Armada ${ }^{121}$.

A situação para o governo passa a se tornar de fato ameaçadora com a derrubada de Júlio de Castilhos, governador deodorista do Rio Grande do Sul, em 12 de novembro, por uma coalizão formada por militares anti-deodoristas e pela

\footnotetext{
116 A Marinha se envolvera no conflito entre a classe militar e a elite imperial com o episódio, ocorrido em março de 1888 (depois da Questão Militar mas dentro do espírito desta), do espancamento de um antigo oficial pela polícia no Rio de Janeiro (John Schulz, O Exército na Política, p. 118). O próprio Clube Militar, fundado em 1887, contaria com a participação de oficiais da Marinha como Jaceguai e Custódio de Melo (ver R. Magalhães Júnior, volume I, pp. 288 e 312). 117 O Major Lauro Sodré, Governador do Pará, foi o único presidente estadual a condenar abertamente o golpe de 3 de novembro (José Maria Bello, p. 80).

${ }_{118}$ Ver Edgard Carone, A República Velha (Evolução Política), pp. 59 e 66-67, e R. Magalhães Júnior, volume II, pp. 324-325.

${ }^{119}$ Edgard Carone, A República Velha (Evolução Política), p. 59.

${ }^{120}$ Edgard Carone, A República Velha (Evolução Política), p. 59.

${ }^{121}$ R. Magalhães Júnior, volume II, p. 370.
} 
oposição local ${ }^{122}$. No Rio de Janeiro, uma grande conspiração envolvendo militares oposicionistas (Floriano, Custódio de Melo, Wandenkolk, José Simeão de Oliveira, etc.), algumas figuras políticas de relevo como Aníbal Falcão, Gonçalves Ramos, Quintino Bocaiúva e Demétrio Ribeiro, e contando com o apoio do PRP ${ }^{123}$ levará à derrubada de Deodoro: na manhã de 23 de novembro de 1891 uma esquadra revoltosa comandada pelo Almirante Custódio José de Melo e apoiada, em terra, pelas escolas militares e por unidades do Exército, força a renúncia do Marechal, que entrega o poder pacificamente ao Vice-Presidente ${ }^{124}$. Sentindo-se traído por vários de seus colegas de farda, Deodoro pede a reforma ${ }^{125}$ e a seu pedido serão dispensadas as honras militares após sua morte ${ }^{126}$.

Como afirma Campos Sales em suas memórias (ver p. 51), o marechal Deodoro, soldado valoroso e cidadão patriota, não era um estadista, e o Sr. Lucena, seu ministro, tinha educado o próprio espírito na escola parlamentar, sob cujo regime o primeiro-ministro da Coroa tem sempre, como a suprema razão de Estado, a medida da dissolução para as câmaras insubmissas. Portanto, se Deodoro fora importante na derrubada de uma ordem já superada, o Deodorismo significava uma estagnação, um obstáculo à evolução histórica do Brasil. O Florianismo, através de seu autoritarismo progressista, será a força que permitirá essa evolução.

\footnotetext{
${ }^{122}$ Ver R. Magalhães Júnior, volume II, pp. 367-369.

${ }^{23}$ Ver Edgard Carone, A República Velha (Evolução Política), pp. 64-68.

${ }^{124}$ José Maria Bello, p. 80, e Edgard Carone, A República Velha (Evolução Política), p. 68.

${ }^{125}$ R. Magalhães Júnior, volume II, p. 374-375.

${ }^{126}$ R. Magalhães Júnior, volume II, pp. 385-386.
} 


\section{CAPÍTULO III: O FLORIANISMO E A LUTA PELA HEGEMONIA POLÍTICA}

(1891-1897)

\section{A) $O$ governo da coalizão anti-deodorista (23 de novembro de 1891 a 12 de maio de 1892).}

1) $O$ novo governo.

Jamais entre nós um Governo foi recebido pela Nação debaixo de melhores auspícios, como afirma Custódio José de Melo em suas memórias ${ }^{1}$ a respeito do governo presidencial instalado em 23 de novembro de 1891. De fato, para os grupos econômicos, brasileiros e estrangeiros, que se sentiram lesados pela política financeira irresponsável de Deodoro/Rui Barbosa e Deodoro/Lucena, a subida do Marechal Floriano Peixoto ao poder significava um alívio imediato. Telegramas vindos de Londres e de Paris mostravam a satisfação dos meios financeiros europeus com a queda da ditadura deodorista e o fim de sua política emissionista ${ }^{2}$. Em seu manifesto de posse, Floriano louvava a ação armada que depusera o governo ditatorial, assim como a abnegação e o patriotismo de Deodoro, que renunciara ao poder para evitar uma luta fratricida; afirmava sua fidelidade às liberdades democráticas e ao sistema federativo, seu apego à Lei e à ordem, e defendia uma política econômica mais sóbria, isto é a administração da Fazenda com a mais severa economia e a maior fiscalização no emprego da renda do Estado ${ }^{3}$. No mesmo dia 23, o novo governo revogava o decreto de 3 de novembro que estabelecera o estado de sítio na Capital Federal e em Niterói e fechara o Congresso, e convocava esse mesmo Congresso para se reunir no dia 18 de dezembro; além disso, entre outras medidas, mandava soltar os militares

\footnotetext{
${ }^{1} 1^{\circ}$ tomo, p. 127.

${ }^{2}$ História Nova do Brasil, pp. 123-124.

3 Ver Edgar Carone, A Primeira República (1889-1930) - Texto e Contexto, pp. 22-24.
} 
presos pela ditadura deodorista ${ }^{4}$. Em suma, ao tomar posse do governo presidencial, Floriano aparecia reunindo as seguintes características: respeito à legalidade e às liberdades democráticas, defesa de uma política econômica ortodoxa e "responsável", e desejo de estabilidade política, tão cara a grupos como o PRP e seus aliados estrangeiros (sobretudo a alta finança européia ${ }^{5}$ ).

O ministério do novo governo vai contar com a presença de elementos da frente anti-deodorista: para as pastas militares, são nomeadas duas lideranças importantes da conspiração militar contra Deodoro, isto é para a pasta da Guerra o General José Simeão de Oliveira e para a da Marinha o Almirante Custódio José de Melo ${ }^{6}$; para o Ministério da Fazenda é nomeado Francisco de Paula Rodrigues Alves, um monarquista que aceitara a República como fato consumado mas que, por ser paulista e estar ligado ao café, acabara se ligando ao $\mathrm{PRP}^{7}$; para a Agricultura, é nomeado Antão Gonçalves de Faria, um republicano dissidente do Rio Grande do Sul, isto é um dissidente do Castilhismo ${ }^{8}$; Constantino Luís Paleta, Ministro do Exterior, faz parte da oposição ao governador deodorista Cesário Alvim em Minas Gerais; como exceção, temos o pernambucano José Higino Duarte Pereira, aliado de J. S. Correia da Silva, governador deodorista de seu Estado, na pasta da Justiça ${ }^{9}$. Assim como no governo instalado a 15 de novembro de 1889 Deodoro simbolizava a coalizão republicana, a 23 de novembro de 1891 Floriano simboliza a coalizão anti-deodorista.

\footnotetext{
${ }^{4}$ Edgard Carone, A República Velha (Evolução Política), p. 70.

${ }^{5}$ Por ocasião da queda de Deodoro, o Jornal do Comércio publicava uma entrevista com os Rothschild, na qual expressavam o seu contentamento pelas mudanças na política brasileira; o mesmo jornal, em 26 de novembro, divulgava um telegrama de Paris afirmando que a queda do Marechal produzira "excelente impressão" na Europa, tanto nas rodas políticas como nas financeiras, os fundos brasileiros tendo considerável alta na Bolsa de Paris (ver História Nova do Brasil, p. 124).

${ }^{6}$ Edgard Carone, A República Velha (Evolução Política), p. 70.

7 José Maria Bello, pp. 88 e 173.

${ }^{8}$ Edgard Carone, A República Velha (Evolução Política), pp. 70 e 104. O tema do Castilhismo será abordado mais para frente.

${ }_{9}$ Roberto Macedo, pp. 73-74. Sendo que o governo de Floriano Peixoto vai evoluir para um governo de tipo pessoal, não será do nosso interesse fazer a relação das constantes mudanças ministeriais ocorridas entre 23 de novembro de 1891 e 15 de novembro de 1894. Esta relação que apresentamos tem como função mostrar o caráter anti-deodorista do primeiro ministério de Floriano.
} 
Este novo governo não somente será anti-deodorista na sua composição, como também em sua política.

No que diz respeito à economia, Rodrigues Alves, um liberal ortodoxo, vai iniciar uma política de saneamento monetário, equilíbrio financeiro e valorização da moeda nacional ${ }^{10}$, procurando por um fim à orgia financeira do Período Deodoro; as emissões passam a ser controladas pelo Tesouro Nacional ${ }^{11}$. Notemos que esta política anti-inflacionista, realizada por um membro do PRP, visava favorecer a elite cafeeira paulista, sobretudo o grande capital cafeeiro, cujas atividades econômicas, como por exemplo o setor ferroviário, dependiam de material importado e de empréstimos externos, o que exigia moeda e economia estáveis $^{12}$. Por outro lado, esta mesma política anti-inflacionista era um golpe na burguesia bancária do Rio de Janeiro, que via finda sua era de enriquecimento e especulações.

Enquanto isso, Floriano e os ministros da Marinha, Custódio de Melo, e da Guerra, Simeão de Oliveira, vão iniciar uma política de derrubada dos governadores aliados de Deodoro e Lucena, política que terá início no mesmo mês de novembro e só terminará em março de 1892. Essa política de derrubadas vai se apoiar em movimentos oposicionistas locais, que terão o beneplácito e em alguns casos o auxílio militar direto do Governo Federal ${ }^{13}$. Com exceção do Rio Grande do Sul, onde o governador aliado de Deodoro já fora deposto antes mesmo da queda deste, e do Pará, onde o Major Lauro Sodré fora o único governador a condenar abertamente o golpe de 3 de novembro ${ }^{14}$, as deposições não vão poupar nenhum governo estadual. Em alguns casos a transmissão de poder será feita de forma pacífica, como nos estados do Rio de Janeiro, Minas Gerais, Santa Catarina, Paraná e Rio Grande do Norte; em outros, como em São Paulo, Bahia, Ceará, Mato Grosso, Pernambuco, Paraíba e Amazonas, as derrubadas se darão de forma violenta, com insurreições coronelísticas e combates nas capitais. Por outro lado, a substituição dos governadores depostos

\footnotetext{
${ }^{10}$ Renato M. Perissinotto, p. 60.

${ }^{11}$ Renato M. Perissinotto, p. 60.

${ }^{12}$ Renato M. Perissinotto, p. 60.

${ }^{13}$ Edgard Carone, A República Velha (Evolução Política), pp. 72-73.

${ }^{14}$ José Maria Bello, p. 80.
} 
não ocorrerá segundo um critério único: em alguns estados, como Pernambuco e Ceará, os governadores empossados serão militares; em outros, como na Bahia e no Mato Grosso, o posto de presidente estadual cairá, na maioria das vezes após uma sucessão de governos provisórios de curta duração, nas mãos de lideranças políticas locais. Em São Paulo e Minas Gerais, dois estados particularmente prejudicados pelas intervenções federais do Governo Deodoro/Lucena, os movimentos oposicionistas triunfam: em São Paulo, o PRP retoma o controle com a derrubada de Américo Brasiliense em dezembro de 1891 e a eleição de Bernardino de Campos em agosto de 1892, e em Minas Cesário Alvim cai em fevereiro de 1892 para a posse, em maio do mesmo ano, de Afonso Pena ${ }^{15}$.

Embora Floriano, Custódio e Simeão estejam por trás dessas revoltas estaduais, a saída deste último do governo em fevereiro de $1892^{16}$ em resposta às constantes intervenções do Chefe de Estado em sua pasta ${ }^{17}$, faz com que a política de deposições venha a ser obra exclusiva da dupla Floriano/Custódio. $\mathrm{O}$ Marechal recém-instalado no poder, embora tendo suas tendências cesaristas, precisava naquele momento dividi-lo com o Ministro da Marinha; este, um oficial de valor e de prestígio mas ao mesmo tempo indivíduo vaidoso e ambicioso ${ }^{18}$, aspirava a ser uma espécie de condestável do novo governo e do regime republicano $^{19}$, e Floriano, profundo conhecedor dos homens do seu tempo ${ }^{20}$, percebendo as aspirações políticas de Custódio, deixava-o impor suas diretrizes enquanto procurava consolidar sua posição de liderança dentro do Exército ${ }^{21}$. Por exemplo, instado por Custódio, Floriano dá seu apoio aos sucessivos e precários governos anticastilhistas no Rio Grande do $\mathrm{Sul}^{22}$, mesmo que, como veremos mais adiante, suas tendências progressistas e autoritárias venham a transformá-lo num aliado natural do Castilhismo.

\footnotetext{
${ }^{15}$ Para maiores detalhes sobre as deposições estaduais, ver Edgard Carone, A República Velha (Evolução Política), pp. 71-84.

${ }^{16}$ Roberto Macedo, p. 130.

${ }^{17}$ Edgard Carone, A República Velha (Evolução Política), p. 87.

${ }^{18}$ Hélio Leôncio Martins, p. 121.

19 José Maria Bello, pp. 96-97.

${ }^{20}$ Euclides da Cunha, Os Sertões, p. 419.

${ }^{21}$ Hélio Leôncio Martins, p. 120.

22 José Maria Bello, p. 97.
} 
Portanto, podemos dizer que, depois da aventura deodorista, a ascensão de Floriano parecia ser o início de uma era de "políticas responsáveis" dentro da melhor tradição liberal-conservadora: retorno à ordem constitucional, composição do ministério por uma coalizão anti-deodorista (incluindo-se aí um representante do PRP), política econômica ortodoxa e política de desalojamento dos aliados de Deodoro as principais posições de mando do país. Como afirma José Maria Bello (p. 98), reagindo contra o golpe de Deodoro, pela restauração do congresso dissolvido, Floriano parecia encarnar a ordem jurídica contra a anarquia e o militarismo.

\section{2) A reação deodorista e a vitória governamental.}

A política de Floriano/Custódio de derrubada dos governadores aliados de Deodoro, somada à política financeira de Rodrigues Alves de proibição de novas emissões, vai dar origem a um ciclo de revoltas deodoristas, que ocorrerão no Rio de Janeiro. Sucintamente, podemos dizer que essas revoltas são fruto do descontentamento de três grupos: 1) militares seguidores do presidente deposto cuja ação política Edgard Carone chama de jacobinismo deodorista, antecessor do florianista ${ }^{23}$; 2) lideranças políticas alçadas do poder em seus estados depois do 23 de novembro; 3) banqueiros do Encilhamento prejudicados pela política ortodoxa do Ministro da Fazenda ${ }^{24}$.

A reação deodorista não se faz esperar: já nos dias 13 e 14 de dezembro de 1891 explode a Revolta do Encouraçado $1^{\circ}$ de Março, que consistiu numa sucessão de motins de marinheiros que, sob pretexto de estarem se revoltando contra maus tratos por parte da oficialidade, procuravam criar um ambiente para a derrubada do novo governo. Rapidamente reprimidos pelas forças do ContraAlmirante José Marques Guimarães, os revoltosos são presos e enviados à

\footnotetext{
${ }^{23}$ A República Velha (Evolução Política), p. 145. Carone, na p. 48, se refere ao jacobinismo (brasileiro, bem entendido) como movimento de cunho militarista em contraposição ao republicanismo civil, característico, por exemplo, do PRP.

${ }^{24}$ John Schulz, O Exército na Política, p. 173.
} 
Fortaleza de Santa $\mathrm{Cruz}^{25}$. Em 19 de janeiro de 1892, nova revolta, de maior amplitude, explode na própria Fortaleza de Santa Cruz, envolvendo 163 presos militares, entre eles 66 marinheiros participantes dos motins de dezembro. $O$ Sargento do Exército Silvino Honório de Macedo, um admirador de Deodoro, assume a liderança da revolta, que, após ter dominado a guarnição local, se expande rapidamente para as fortalezas da Laje e do Pico. Silvino faz substituir a bandeira nacional pela vermelha e intima Floriano a entregar o cargo a Deodoro, sob pena de os canhões das fortalezas rebeladas bombardearem a Capital Federal. A repressão à revolta será feita através de uma ação simultânea da Esquadra, comandada pelo próprio Custódio de Melo, e de forças do Exército $\left(7^{\circ}\right.$ e $10^{\circ}$ Batalhões de Infantaria), sob o comando do General Antônio Enéas Gustavo Galvão, Ajudante-General do Exército. Depois de mais de um dia de luta e de várias dezenas de mortos, os combates cessam e os rebeldes entregam as armas. Respondendo a Conselho de Guerra, Silvino afirma que ao iniciar a rebelião contava com a participação de autoridades militares, como o Almirante Saldanha da Gama e o Marechal Almeida Barreto, assim como de personalidades políticas, participação esta que acabou não acontecendo, o que teria transformado a revolta num fiasco; a cumplicidade de personalidades da elite civil e militar com a Revolta do Sargento Silvino nunca seria provada ${ }^{26}$.

A terceira manifestação deste ciclo vai envolver oficiais-generais, daí o nome de Manifesto dos Treze Generais. Tendo fracassado a tentativa golpista de 19 de janeiro, os deodoristas procurarão utilizar argumentos constitucionais para impedir a permanência de Floriano: segundo a Constituição, artigo 42, se no caso de vaga, por qualquer causa, da presidência ou vice-presidência, não houverem decorrido dois anos do período presidencial, proceder-se-á a nova

\footnotetext{
${ }^{25}$ Ver Edgard Carone, A República Velha (Evolução Política), p. 85, e Glauco Carneiro, p. 51.

${ }^{26}$ Para maiores detalhes sobre esta revolta, ver Glauco Carneiro, capítulo II, e Sylvio Peixoto, pp. 37-77. Segundo Custódio de Melo (p. 224), os conspiradores teriam planejado um movimento revolucionário partindo dos estados de Mato Grosso, São Paulo, Rio Grande do Sul e talvez Pernambuco, para depois explodir na Capital Federal; podemos, portanto, imaginar que houve uma inversão mal sucedida, já que a Revolta do Sargento Silvino explodiu antes das fracassadas revoltas nesses estados, que por sua vez só aconteceriam no final do mês de janeiro (ver Edgard Carone, A República Velha (Evolução Política), p. 87).
} 
eleição ${ }^{27}$. Floriano estaria portanto condenado a convocar novas eleições para em seguida deixar o poder. No entanto, o Marechal e seus aliados se apoiarão nas Disposições Transitórias (artigo $1^{\circ}$ ) da Constituição, onde está escrito que no caso da primeira eleição presidencial (ocorrida em 25 de fevereiro de 1891 com a eleição de Deodoro para Presidente e Floriano para Vice), realizada pelo Congresso Constituinte, o presidente e o vice-presidente, eleitos na forma deste artigo, ocuparão a presidência e a vice-presidência da República durante o primeiro período presidencial, sendo que para essa eleição não haverá incompatibilidades $^{28}$. Embora extremamente vago quanto ao problema da sucessão em caso de vacância do cargo de Presidente, o governo vai se apoiar neste artigo para justificar sua permanência ${ }^{29}$. Floriano ainda conta com o apoio de Custódio, e o PRP, representante da elite econômica mais poderosa do país, embora tendo oscilado durante um curto período entre a campanha por novas eleições e a permanência do Marechal, vai também dar seu apoio ao governo ${ }^{30}$. De qualquer forma, treze oficiais-generais do Exército e da Marinha lançam, a 31 de março de 1892, um manifesto condenando a política governamental de deposições estaduais e exortando Floriano a convocar novas eleições presidenciais $^{31}$; por mais que essa exortação possa parecer desinteressada e de grande elevação moral, notemos que entre os signatários constam os nomes do Marechal José de Almeida Barreto, suspeito de conivência com a Revolta do Sargento Silvino, do General José Clarindo de Queiroz, governador deodorista do Ceará deposto em fevereiro de $1892^{32}$, e do General João Severiano da Fonseca, irmão de Deodoro. Embora não havendo apenas deodoristas entre os signatários, como nos mostra a presença, entre eles, do Contra-Almirante José Marques Guimarães, repressor da Revolta do Encouraçado $1^{\circ}$ de Março, e do "eterno opositor" Eduardo Wandenkolk ${ }^{33}$, este manifesto assume claramente o caráter de

\footnotetext{
${ }^{27}$ Fernando H. Mendes de Almeida, p. 118.

${ }^{28}$ Fernando $\mathrm{H}$. Mendes de Almeida, pp. 139-141.

29 José Maria Bello, p. 90.

${ }^{30}$ Edgard Carone, A República Velha (Evolução Política), pp. 89-90.

${ }^{31}$ Edgard Carone, A Primeira República (1889-1930) - Texto e Contexto, pp. 25-26.

${ }^{32}$ Ver Edgard Carone, A República Velha (Evolução Política), pp. 83-84.

33 O Vice-Almirante Wandenkolk fora, como vimos, integrante do Governo Provisório até a demissão coletiva de 21 de janeiro de 1891. Candidato a Vice-Presidente na chapa de Deodoro,
} 
reação de militares insatisfeitos com a ordem pós-deodorista, e por isso pode ser encaixado dentro deste ciclo. A reação de Floriano é enérgica: contando com o apoio do Clube Militar, reforma os treze oficiais ${ }^{34}$.

A quarta e última grande revolta deste ciclo ocorre em 10 de abril de 1892. Trata-se de uma manifestação organizada por civis e militares em homenagem ao já muito doente Deodoro da Fonseca. Nela, uma multidão liderada pelo TenenteCoronel Mena Barreto, um dos integrantes da força insurrecional de 15 de novembro de 1889, e por personalidades como J. J. Seabra, Pardal Mallet e Clímaco Barbosa se dirige ao Palácio Itamarati para proferir insultos e ameaças ao governo. Esta homenagem é de fato um pretexto para o desencadeamento de um movimento revolucionário visando a derrubada de Floriano; este, no entanto, se dirige ao local da manifestação e, enquanto o $23^{\circ}$ Batalhão de Infantaria prende vários revoltosos, dá pessoalmente ordem de prisão a Mena Barreto, que se entrega no Ministério da Guerra ${ }^{35}$. Outras prisões se seguem, como as de J. J. Seabra, Pardal Mallet, Olavo Bilac e Severiano da Fonseca ${ }^{36}$. O governo declara estado de sítio para o Distrito Federal $^{37}$ e ordena a prisão de vários elementos oposicionistas envolvidos nas conspirações antigovernamentais que se seguiram ao 23 de novembro: militares como José Clarindo de Queiroz, Mena Barreto, Eduardo Wandenkolk, Almeida Barreto, Thaumaturgo de Azevedo (governador deodorista do Amazonas deposto em janeiro) e Jacques Ourique, e civis como J. J. Seabra, Pardal Mallet, José do Patrocínio e o Conde de Leopoldina (um dos grandes banqueiros do Encilhamento) são deportados para localidades no Amazonas; outras personalidades, como o poeta, escritor e jornalista deodorista Olavo Bilac, são detidas em fortalezas militares no Rio de Janeiro ${ }^{38}$.

fora derrotado por Floriano Peixoto. Posteriormente, se voltara contra Deodoro, participando inclusive da conspiração que desembocaria em sua derrubada em 23 de novembro de 1891; no entanto, mal o Governo Floriano tinha iniciado, lá estava ele entre os opositores que pediam novas eleições.

${ }_{34}^{34}$ John Schulz, O Exército na Política, p. 173.

${ }^{35}$ Edgard Carone, A República Velha (Evolução Política), pp. 93-94 e Sylvio Peixoto, pp. 107111.

${ }^{36}$ Sylvio Peixoto, pp. 111-112.

${ }^{37}$ Edgard Carone, A República Velha (Evolução Política), p. 94.

${ }^{38}$ Edgard Carone, A República Velha (Evolução Política), pp. 94-95. 
Essas revoltas ocorridas na Capital Federal são acompanhadas por outras bem mais inexpressivas no Rio Grande do Sul, no Mato Grosso e em São Paulo, revoltas rapidamente sufocadas ${ }^{39}$. De qualquer forma, em junho do mesmo ano será concedida, sob pressão de deputados oposicionistas como Artur Rios, Amaro Cavalcanti e Aristides Lobo, e até de aliados do governo, como Campos Sales, Prudente de Moraes e Francisco Glicério, a anistia aos deodoristas; em agosto os elementos desterrados no Amazonas são libertados ${ }^{40}$. Além do mais, a morte de Deodoro, em 23 de agosto de $1892^{41}$, colocará um fim, de forma definitiva, nas agitações anti-governamentais que eram feitas em seu nome. Ao contrário do Florianismo, que permanecerá como corrente política após a morte de Floriano, o Deodorismo morre junto com Deodoro. A partir daí, a oposição a Floriano será feita sob outras bandeiras e junto com outros grupos.

Enquanto acompanhava, dentro do Arsenal de Marinha, a Revolta do Sargento Silvino, Floriano teria dito: Não é à minha pessoa que os inimigos da situação movem tanta guerra, mas às portas do Tesouro que defenderei a todo transe com honra e probidade ${ }^{42}$. Isto é, segundo o próprio Floriano Peixoto, a insurreição de 19 e 20 de janeiro não seria uma reação contra sua liderança ou contra qualquer tendência autoritária que seu governo pudesse ter apresentado, mas sim contra sua política econômica, antagônica à do Período Deodoro. A importância desta afirmação, seja ela real ou uma romantização da crônica histórica brasileira, reside no fato de que de certa forma ela se refere ao caráter reacionário das revoltas deodoristas, isto é à sua tentativa de volta à política econômica imperial pós-escravista: o jacobinismo deodorista seria um instrumento, consciente ou não, de ramos da antiga elite monárquica desejosos de se apoderar do aparelho de Estado republicano. A primeira tentativa neste sentido fracassara com a queda de Deodoro no final de 1891, e a segunda tentativa, embora desesperada, consistira em insurreições militares

\footnotetext{
${ }^{39}$ Edgard Carone, A República Velha (Evolução Política), p. 87.

${ }^{40}$ Edgard Carone, A República Velha (Evolução Política), pp. 95-97.

${ }^{41}$ R. Magalhães Júnior, volume II, p. 385.

${ }^{42}$ Cyro Silva, p. 137.
} 
visando a derrubada do governo da coalizão anti-deodorista. Portanto, não se trata ainda de uma reação anti-florianista ${ }^{43}$, porque Floriano neste momento apenas representa uma coalizão que derrubou Deodoro e portanto seu governo ainda não tem de fato o peso de sua liderança.

De qualquer forma, a vitória governamental sobre as revoltas deodoristas vai dar mais segurança a Floriano para iniciar uma política própria e independente de seus aliados de 23 de novembro: a firmeza do Marechal no combate aos rebeldes será um fator importante para a consolidação de sua posição de liderança dentro do governo ${ }^{44}$, o que tornará posteriormente desnecessária sua aliança com o personalista Custódio de Melo.

B) Evolução da política florianista de 12 de maio de 1892 a 5 de fevereiro de 1893.

1) Uma nova orientação.

Com a saída de Simeão de Oliveira do Ministério da Guerra e sua substituição pelo General Francisco Antônio de Moura ${ }^{45}$, que será um fiel executor da política de Floriano, a coalizão de 23 de novembro sofre um abalo. No entanto, é com o programa apresentado pelo Marechal no Congresso a 12 de maio de 1892, e ao qual nos referimos no capítulo I, que tem início uma nova fase do Governo Floriano: este programa, onde encontramos explícita uma política de desenvolvimento nacional (estímulo à indústria, investimento em ferrovias, em educação, etc.), é a afirmação ideológica de Floriano dentro do governo, e a partir daí podemos dizer que nasce uma política florianista, herdeira do progressismo militar da segunda metade do século XIX.

\footnotetext{
${ }^{43}$ A própria postura de Rui Barbosa de "defensor das liberdades públicas" ao denunciar a política de Floriano/Custódio de deposições estaduais e ao pedir habeas-corpus aos presos políticos de abril 1892 (José Maria Bello, pp. 88, 89 e 99) não seria a reação de um liberal-democrata que se sentia ultrajado pelo autoritarismo florianista, e sim a reação de um aliado da plutocracia financeira do Império, e, portanto, de um nostálgico do período deodorista, contra a política financeira de Rodrigues Alves.

${ }^{44}$ Hélio Leôncio Martins, p. 70.

${ }^{45}$ Roberto Macedo, p. 130.
} 
Esta nova orientação ideológica não deixa de influir na composição do ministério: Rodrigues Alves, não se sentindo apoiado pelo Chefe de Estado em sua política de valorização monetária e de corte nos gastos públicos ${ }^{46}$, deixa sua pasta e é substituído, em 31 de agosto de 1892, pelo Tenente-Coronel Inocêncio Serzedelo Corrêa ${ }^{47}$, seguidor do já finado Benjamin Constant e um representante da oficialidade positivista do Exército, além de defensor convicto da industrialização ${ }^{48}$.

Como dissemos no capítulo I, o Governo Floriano, no período em que Serzedelo ocupa a pasta da Fazenda (31 de agosto de 1892 a 27 de abril de 1893), fará uma política de fornecimento de crédito à indústria e de medidas protecionistas para determinados setores da atividade industrial. No que diz respeito a esta última, o governo, através de uma lei aprovada pelo Congresso em novembro de 1892 , eleva de $30 \%$ as tarifas alfandegárias sobre produtos têxteis, móveis de luxo e mercadorias de luxo em geral, ao mesmo tempo em que reduz de $30 \%$ as tarifas sobre máquinas importadas, implementos agrícolas e gêneros alimentícios básicos ${ }^{49}$; a redução da taxação sobre esses produtos se explica pelo fato de que o Brasil do final do século XIX, um país essencialmente agrário e com uma burguesia industrial incipiente e precária, era carente de um setor produtor de bens de capital ${ }^{50}$, o que faria com que a indústria nacional saísse prejudicada de uma política de protecionismo generalizado, que encareceria, por exemplo, a maquinaria estrangeira da qual aquela necessitaria para seu maior desenvolvimento. Quanto à política de fornecimento de crédito, ela se fará através dos bancos, aos quais caberá repassar o dinheiro fornecido pelo governo, à indústria ${ }^{51}$. Embora, à primeira vista, esta política possa parecer um retorno ao emissionismo de Rui Barbosa e do Barão de Lucena, no fundo ela é radicalmente diferente. Em primeiro lugar porque sua finalidade é desenvolver a indústria nacional, enquanto que no Período Deodoro o que encontrávamos era uma

\footnotetext{
46 José Maria Bello, p. 95.

${ }^{47}$ Roberto Macedo, p. 82.

48 John Schulz, O Exército na Política, p. 177.

49 John Schulz, O Exército na Política, p. 180.

${ }^{50}$ Renato M. Perissinotto, p. 134.

${ }^{51}$ Embora houvesse pressão para que Floriano emprestasse dinheiro diretamente aos industriais, aquele preferiu faze-lo através dos bancos (John Schulz, O Exército na Política, pp. 177-178).
} 
política de indenização aos antigos proprietários de escravos e de aumento do meio circulante visando beneficiar a burguesia bancária do Rio de Janeiro. Por outro lado, enquanto que no Período Deodoro o poder de emissão era ilimitado e sem nenhum controle, com Floriano e Serzedelo ele passa a ser controlado pelo Estado: além de exigir, por parte dos bancos encarregados de repassar o dinheiro, títulos que garantissem os adiantamentos ${ }^{52}$, Floriano decretará, em 17 de dezembro de 1892, a fusão do Banco do Brasil e do Banco da República num novo Banco da República do Brasil, o único com o privilégio de emitir dinheiro e que, embora permanecendo privado, terá seu presidente, seu vice-presidente e um de seus sete diretores nomeados pelo governo (que ainda terá o poder de veto sobre todas as suas decisões e que exigirá que dois terços dos industriais beneficiados por essa política de fornecimento de crédito tenham suas fábricas fora da Capital Federal) ${ }^{53}$. Depois da política de emissionismo desenfreado de Rui Barbosa e Lucena e do liberalismo ortodoxo de Rodrigues Alves, passamos a um dirigismo econômico (logicamente ainda bem longe do dirigismo econômico do período do Estado Novo) visando o desenvolvimento da indústria nacional. Quanto à alta finança européia, ela já teria demonstrado insatisfação para com a nova orientação econômica, como nos faz supor o telegrama, exposto pelo Jornal do Comércio, dos Rothschild (os mesmos que viram com bons olhos a derrubada de Deodoro) ao Ministro da Fazenda, no qual alertavam para os "efeitos maléficos" da emissão de apólice para auxílio às indústrias ${ }^{54}$.

\footnotetext{
52 John Schulz, O Exército na Política, p. 178.

${ }^{53}$ John Schulz, O Exército na Política, p. 180. Notamos aqui um sinal de planejamento militar da organização industrial brasileira, no intuito de se evitar a concentração industrial numa só região. Uma melhor distribuição das atividades industriais por todo o país seria a nosso ver uma garantia contra um ataque externo que visasse destruir o potencial econômico brasileiro, assim como uma garantia contra regiões prósperas que viessem a alimentar intuitos separatistas.

${ }^{54}$ História Nova do Brasil, p. 126. A própria saída, dois meses depois, de Rodrigues Alves da pasta da Fazenda talvez tenha alguma relação com a insatisfação de seus aliados capitalistas ingleses com o governo do qual participava.
} 


\section{2) Florianismo e Castilhismo.}

Quando da Proclamação da República, o Rio Grande do Sul estava sob a hegemonia do Partido Liberal, que nesta província se apresentava como herdeiro dos ideais da Revolução Farroupilha e representava uma elite ligada à pecuária (estancieiros e charqueadores) $^{55}$. Liderado, desde 1878, por Gaspar da Silveira Martins $^{56}$, o Partido Liberal, por ser a voz da principal atividade econômica da província $^{57}$, reinava absoluto. Na década de 1880 , sua ação política vai consistir na reivindicação por ferrovias, pela redução de impostos de importação e de exportação e por mais créditos das casas exportadoras para as estâncias e charqueadas $^{58}$. No entanto, favoráveis à manutenção da escravidão ${ }^{59}$, os liberais gaúchos permaneciam fiéis à Monarquia: o Estado imperial era, como vimos, condição para a permanência do escravismo e, embora os liberais outrora tivessem levantado a bandeira da descentralização administrativa ${ }^{60}$ (um dos legados da Farroupilha), isto não quer dizer que eles fossem defensores da Federação, que, através das barreiras entre as províncias, poderia comprometer sua economia, que vivia de abastecer o mercado interno.

Já os republicanos, agrupados desde 1882 no Partido Republicano RioGrandense $(\mathbf{P R R})^{61}$, eram minoria na região e tinham seu núcleo formado por

\footnotetext{
55 Sandra Jatahy Pesavento, A Revolução Federalista, p. 44.

${ }^{56}$ Sandra Jatahy Pesavento, A Revolução Federalista, p. 46.

${ }_{57} \mathrm{O}$ principal produto da província era o charque (Sandra Jatahy Pesavento, A Revolução Federalista, p. 38). Sua produção funcionava da seguinte maneira: os charqueadores compravam o gado dos estancieiros, para depois preparar a carne de forma rudimentar em estabelecimentos (as charqueadas) que se situavam em torno dos centros urbanos, e as exportavam para São Paulo, Rio de Janeiro e as províncias do Nordeste, onde esta carne servia de alimento para os escravos (Luiz Roberto Targa, p. 187).

${ }_{58}$ Sandra Jatahy Pesavento, A Revolução Federalista, pp. 46-47.

59 Durante a discussão do Projeto Dantas, que libertava os escravos sexagenários, o Senador Silveira Martins chegara a dizer, para condenar o projeto: Será o suplício da Constituição, uma falta de consciência e escrúpulo; um verdadeiro roubo, a naturalização do comunismo, a ruína geral, a situação do Egito, a bancarrota do Estado, o suicídio da Nação (História Nova do Brasil, p. 143). Embora nas estâncias não houvesse trabalho escravo, este era utilizado nas charqueadas (Luiz Roberto Targa, pp. 187-188) e o charque gaúcho era destinado, sobretudo por causa de sua má qualidade (Sandra Jatahy Pesavento, História do Rio Grande do Sul, p. 69), à alimentação da população escrava em outras províncias brasileiras, o que pode explicar a posição do líder liberal em favor da manutenção do escravismo.

${ }^{60}$ Sandra Jatahy Pesavento, História do Rio Grande do Sul, p. 52.

${ }^{61}$ Sérgio da Costa Franco, Júlio de Castilhos e sua época, p. 21.
} 
jovens profissionais liberais das áreas urbanas (médicos, engenheiros, advogados $)^{62}$. Seu programa político, de orientação positivista e lançado em 1884, defendia, entre outras coisas, a substituição da Monarquia pela República Federativa, a abolição da escravidão, a liberdade de associação e de culto, a liberdade de comércio e indústria, a liberdade de ensino, a criação do imposto territorial e a eliminação dos impostos indiretos, uma administração austera (sem gastos de caráter improdutivo) e reformas laicizantes como o casamento civil, o registro civil e a secularização dos cemitérios ${ }^{63}$. Liderados pelo jovem advogado positivista Júlio Prates de Castilhos, os republicanos procurariam compensar sua inferioridade numérica através de uma atuação virulenta e de uma rígida disciplina partidária. Através do jornal A Federação, órgão oficial do PRR, os republicanos defenderiam a abolição da escravidão independente de qualquer indenização para os proprietários ${ }^{64}$; em 1886, o jornal daria todo apoio aos oficiais rebeldes da Questão Militar ${ }^{65}$, cedendo inclusive espaço para Sena Madureira, Deodoro e Pelotas se manifestarem por escrito contra o Gabinete Cotegipe ${ }^{66}$, o que traria aos republicanos o valioso apoio do Exército ${ }^{67}$.

Com a República, o Partido Liberal era apeado do poder e seu líder Silveira Martins, que exercia a presidência da província, exilado na Europa ${ }^{68}$. O PRR tomaria parte na maioria dos governos provisórios estaduais que se sucederam depois do 15 de novembro ${ }^{69}$. Apesar da instabilidade política, os republicanos aproveitariam inteligentemente essa fase transitória para assentar suas bases dentro do aparelho de Estado: funcionários ligados aos antigos liberais eram

\footnotetext{
${ }^{62}$ Muitos desses jovens eram oriundos de famílias de estancieiros que no entanto não faziam parte do próspero eixo Pelotas - Rio Grande - Bagé, que por sua vez estavam representados no Partido Liberal (Sandra Jatahy Pesavento, A Revolução Federalista, pp. 53-54).

${ }^{63}$ Para o programa do PRR, ver Sérgio da Costa Franco, Júlio de Castilhos e sua época, pp. 2427.

${ }^{64}$ Sérgio da Costa Franco, Júlio de Castilhos e sua época, p. 29.

${ }^{65}$ Sérgio da Costa Franco, Júlio de Castilhos e sua época, p. 43.

${ }^{66}$ Ver R. Magalhães Júnior, volume I, pp. 215-223.

${ }^{67}$ Sandra Jatahy Pesavento, A Revolução Federalista, pp. 53-54.

${ }^{68}$ R. Magalhães Júnior, volume II, p. 115.

${ }^{69}$ Edgard Carone (A República Velha (Evolução Política), p. 38) nos fala de uma seqüência vertiginosa de dezoito governos estaduais no Rio Grande do Sul entre a Proclamação da República e a derrubada de Júlio de Castilhos em 12 de novembro de 1891.
} 
substituídos por pessoal de confiança dos republicanos ${ }^{70}$, as antigas câmaras municipais eram dissolvidas e substituídas por juntas nomeadas pelo governo do Estado $^{71}$ e os republicanos dominariam a lista de deputados eleitos para a Assembléia Constituinte Federal ${ }^{72}$. A vitória republicana nas eleições para 0 Congresso Constituinte Estadual em 5 de maio de $1891^{73}$ garantiria a promulgação da constituição, de cunho positivista, do estado e a eleição do líder republicano para o governo estadual, ambas no dia 14 de julho do mesmo ano ${ }^{74}$.

Os sucessos do PRR se deviam não somente à habilidade política e à liderança forte e austera de seu chefe, mas também à sua aliança com o Governo Federal. Embora discordando da linha política deodorista, e sobretudo de sua política financeira ${ }^{75}$, o Castilhismo continuaria a dar seu apoio a Deodoro, amigo de Castilhos desde a Questão Militar, na medida em que a aliança com os militares e o Governo Federal seria uma garantia para a consolidação do poder político do $\mathrm{PRR}$, ainda frágil devido à importante presença dos remanescentes do antigo Partido Liberal na região ${ }^{76}$. A persistência na aliança com o cada vez mais impopular Deodoro e a progressiva concentração do comando dentro do PRR nas mãos de Castilhos levariam a um "racha" dentro do partido, criando-se um movimento de republicanos dissidentes no qual encontraríamos nomes como Barros Cassal, Demétrio Ribeiro, Antão de Faria ${ }^{77}$ e, posteriormente, Assis Brasil $^{78}$. Com o golpe de Estado de 3 de novembro de 1891, Castilhos, que

\footnotetext{
${ }^{70}$ Sérgio da Costa Franco, A Guerra Civil de 1893, p. 21. Como exemplo, podemos citar a demissão dos caudilhos liberais Gumercindo Saraiva e Juca Tigre de seus cargos de delegado de polícia (Sérgio da Costa Franco, Júlio de Castilhos e sua época, p. 64).

${ }^{71}$ Sérgio da Costa Franco, A Guerra Civil de 1893, p. 21.

${ }^{72}$ Ver Sérgio da Costa Franco, Júlio de Castilhos e sua época, pp. 79-81.

${ }^{73}$ Sérgio da Costa Franco, Júlio de Castilhos e sua época, p. 98.

${ }^{74}$ Sérgio da Costa Franco, Júlio de Castilhos e sua época, pp. 99-100.

${ }^{75}$ Por exemplo, governo provisório do General Júlio Anacleto Falcão da Frota (fevereiro a maio de 1890) renunciara, junto com seus aliados republicanos, devido à discordância em relação à criação do banco emissor do Rio Grande do Sul pelo Governo Federal (ver Sérgio da Costa Franco, Júlio de Castilhos e sua época, pp. 68-70).

${ }^{76}$ Sérgio da Costa Franco, Júlio de Castilhos e sua época, p. 72.

${ }^{77}$ Antão de Faria, que, como vimos, exercia o Ministério da Agricultura no governo da coalizão de 23 de novembro, se demitirá de sua pasta em 19 de junho de $1892 \mathrm{com}$ a volta de Júlio de Castilhos ao poder em seu estado. Posteriormente a pasta da Agricultura será suprimida pelo Governo Floriano e integrada num novo Ministério da Indústria, Viação e Obras Públicas (ver Roberto Macedo, p. 89).

${ }^{78}$ Sérgio da Costa Franco, A Guerra Civil de 1893, pp. 17-18 e 24-25.
} 
defendera a eleição de Deodoro durante o período da Assembléia Constituinte ${ }^{79}$, passava a ser identificado com o ditador ${ }^{80}$. Isto provocaria um movimento militar, que de anti-deodorista passaria a anti-castilhista, envolvendo as guarnições militares de Bagé e Rio Grande, as forças navais estacionadas no estado, assim como as forças oposicionistas locais; Castilhos, vendo que todas as autoridades municipais iam sendo depostas e, conseqüentemente, que suas próprias bases de apoio iam desaparecendo, abandonava o poder nove dias depois do golpe de Deodoro $^{81}$, vindo a assumir uma junta governativa composta pelos generais Manuel Luís da Rocha Osório e Domingos Alves Barreto Leite e os republicanos dissidentes Barros Cassal e Assis Brasil ${ }^{82}$.

A ascensão de Floriano encontra o governo do Rio Grande do Sul nas mãos do General Barreto Leite, que tem por vice Barros Cassal ${ }^{83}$. Como vimos, o Marechal, por razões táticas, cede à pressão de seu ministro da Marinha, Custódio de Melo, para que apóie a situação; esta, não conseguindo cooptar os quadros do deposto PRR, tem de aceitar a colaboração dos antigos liberais, desejosos de retornar ao poder; portanto, o domínio da dissidência republicana, carecendo de personalidade e maior definição política, começa a descambar para a anarquia ${ }^{84}$.

Regressando do exílio, Silveira Martins, ao aportar na Capital Federal em 5 de janeiro de 1892, encontra-se com Floriano e, a respeito do regime implantado em 1889 e consolidado pela Constituição de 24 de fevereiro, afirma estar tudo errado; que precisava desfazer-se o que estava feito para adotar-se a república parlamentar $^{85}$. Floriano sentia-se duplamente ameaçado: por ser um líder de

\footnotetext{
${ }^{79}$ Sérgio da Costa Franco, Júlio de Castilhos e sua época, p. 92.

${ }^{80}$ Embora não concordando com o golpe de Deodoro, que fatalmente levaria à queda deste e de seus aliados, Castilhos não queria condená-lo por temer a perda do apoio federal e uma intervenção militar. A 4 de novembro, dia seguinte ao fechamento do Congresso pelos deodoristas, o líder republicano rio-grandense enviava ao Presidente da República um telegrama vago que dizia ordem pública será plenamente mantida aqui. Este apoio pouco convicto ao ato ditatorial serviria, no entanto, de pretexto para uma revolta local contra o domínio do PRR (ver Sérgio da Costa Franco, Júlio de Castilhos e sua época, pp. 103-104).

${ }^{81}$ Edgard Carone, A República Velha (Evolução Política), pp. 77-78.

${ }^{82}$ Sérgio da Costa Franco, A Guerra Civil de 1893, pp. 33-34.

${ }^{83}$ Sérgio da Costa Franco, A Guerra Civil de 1893, p. 34.

${ }^{84}$ Sérgio da Costa Franco, Júlio de Castilhos e sua época, p. 109.

${ }^{85}$ Edgar Carone, A República Velha (Evolução Política), p. 97.
} 
tendências cesaristas, e portanto defensor do predomínio do Poder Executivo sobre o Legislativo, o Parlamentarismo só poderia ser uma ameaça à sua autoridade $^{86}$; por outro lado, Silveira Martins, embora tendo aceito a República como fato consumado ${ }^{87}$, representava a velha elite agrária e escravista do Império, que Floriano e o progressismo militar em geral execravam. O futuro Marechal de Ferro, até por não sentir firmeza nos governos da dissidência republicana $^{88}$ e em sua capacidade de barrar qualquer tentativa dos liberais voltarem ao poder $^{89}$, vai iniciar, a partir de abril de 1892, uma aproximação com os castilhistas $^{90}$.

Por suas posições políticas e ideológicas, o Florianismo fatalmente se transformaria em aliado do Castilhismo. Embora Floriano não fosse positivista, duas tendências uniam esses dois fenômenos: o progressismo e o autoritarismo. Associadas à defesa do desenvolvimento industrial e de um programa de obras públicas ${ }^{91}$, encontramos no discurso castilhista uma defesa do fortalecimento do Estado em detrimento dos egoístas interesses individuais ${ }^{92}$, uma defesa da submissão dos direitos do indivíduo ao bem público ${ }^{93}$, assim como da tutela da sociedade pelo Estado ${ }^{94}$ e de um governo honesto e austero, que esteja encarnado numa liderança cujo valor consiste numa "imaculada pureza de intenções" ${ }^{\text {"95 }}$. A própria Constituição de 14 de Julho (de cunho positivista), que estabelecia um sistema presidencialista com o poder político concentrado nas mãos do Poder Executivo (a Assembléia Estadual, unicameral, tinha apenas funções orçamentárias), o direito à reeleição do presidente estadual, a liberdade

\footnotetext{
${ }^{86}$ Edgard Carone, A República Velha (Evolução Política), p. 100.

${ }^{87}$ José Maria Bello, p. 103.

${ }^{88}$ Entre 12 de novembro de 1891 e 17 de junho de 1892, haverá uma série de cinco governos provisórios apoiados pela dissidência republicana, que Júlio de Castilhos, em artigos do jornal A Federação, chamará pejorativamente de governicho por causa de sua debilidade (ver Sérgio da Costa Franco, A Guerra Civil de 1893, pp. 33-34).

${ }^{89}$ Sérgio da Costa Franco, Júlio de Castilhos e sua época, pp. 122-123.

${ }^{90}$ Sérgio da Costa Franco, A Guerra Civil de 1893, p. 35.

${ }^{91}$ Ricardo Vélez Rodríguez, p. 116.

${ }^{92}$ Ricardo Vélez Rodríguez, p. 115.

${ }^{93}$ Ricardo Vélez Rodríguez, p. 133.

${ }^{94}$ Ricardo Vélez Rodríguez, p. 133.

${ }^{95}$ Ricardo Vélez Rodríguez, p. 105.
} 
religiosa, a liberdade de profissão e de indústria ${ }^{96}$, se encaixava perfeitamente dentro do autoritarismo progressista de Floriano. Por outro lado, um novo grupo político de peso se constituía no estado, reunindo as principais lideranças do Rio Grande do Sul do final do Império: através do Congresso de Bagé, ocorrido em 31 de março de 1892, era fundado, sob a liderança de Silveira Martins e dos irmãos Silva Tavares (estes últimos ligados ao extinto Partido Conservador), o Partido Federalista, agremiação que defendia a instauração de uma república unitária e parlamentar $^{97}$; podemos dizer que este partido, por ter como presidente o velho líder liberal, estaria representando a tradicional elite pecuarista da região, e que portanto o Partido Federalista seria mais uma tentativa por parte de uma fração antiga da elite imperial de voltar ao poder dentro do regime republicano. Logicamente, Floriano, entre uma organização neo-monárquica ${ }^{98}$ como o Partido Federalista e um partido autenticamente republicano formado pelas camadas médias rio-grandenses (caso do PRR), vai optar por este último.

A aproximação de Floriano com os castilhistas vai ser feita através da ação do General Bernardo Vasques, Comandante do $6^{\circ}$ Distrito Militar, sediado em Porto Alegre, que em fins de maio de 1892 entra em contato com militares castilhistas e planeja o retorno do PRR ao poder ${ }^{99}$ (esta aproximação era feita à revelia de Custódio de Melo, favorável à aliança com os governos provisórios da dissidência republicana ${ }^{100}$ ). No dia de 17 de junho de 1892, a Guarda Cívica (milícia estadual) se subleva, e numa operação rápida junto com populares armados (entre eles o General Júlio Falcão da Frota e o próprio Júlio de Castilhos), derruba o Visconde de Pelotas ${ }^{101}$, que governava provisoriamente 0

\footnotetext{
${ }^{96}$ Ver Ricardo Vélez Rodríguez, pp. 59-63.

${ }^{97}$ Edgard Carone, A República Velha (Evolução Política), p. 98. O qualificativo federalista é neste caso enganoso; na verdade, o nome de Partido Federalista foi utilizado apenas como diferencial em relação ao PRR e ao transitório Partido Republicano Federal, agremiação da dissidência republicana. Os verdadeiros federalistas eram na verdade os castilhistas, que defendiam um federalismo radical com ampla autonomia para os estados (ver Glauco Carneiro, pp. 77-78).

${ }_{98}$ Utilizamos este termo com o mesmo sentido que na análise que fizemos do Deodorismo no capítulo II.

${ }_{99}$ Edgard Carone, A República Velha (Evolução Política), p. 100.

${ }^{100}$ Ver Almirante Custódio José de Mello, $1^{\circ}$ tomo, pp. 291-295 e p. 303.

101 Pouco antes de derrubado, ao ver-se sem recursos para oferecer resistência à ofensiva castilhista, Pelotas transmitia o governo a João Nunes da Silva Tavares, situado em seu núcleo em
} 
estado desde 8 de junho. Esta ação, que contou com a neutralidade das tropas federais, deixava explícita a cumplicidade do Governo Federal para com os republicanos $^{102}$. A pedido de Floriano, Castilhos entrega o poder a um correligionário, Vitorino Monteiro, que deve presidir o estado provisoriamente até a realização de novas eleições ${ }^{103}$. Este cede seu lugar, em fins de setembro, a outro castilhista, Fernando Abbott, sob cuja administração serão realizadas as novas eleições estaduais, que elegerão pela segunda vez Júlio de Castilhos para o governo do estado. Também neste período será construída a nova estrutura militar gaúcha, com a transformação, em outubro, da Guarda Cívica em Brigada Militar do Estado, composta de dois batalhões de Infantaria e um regimento de Cavalaria (efetivo total de 1265 homens e outros tantos de corpos de reserva) ${ }^{104}$.

No período compreendido entre 8 de agosto e 15 de dezembro de 1892, Júlio de Castilhos permanece no Rio de Janeiro, onde exerce sua função de deputado federal, entrando em contato direto com Floriano: àquela altura, graças aos contatos mantidos com Júlio de Castilhos, o "Marechal de Ferro" por certo já tivera oportunidade de verificar que o grande líder sulino era um símile seu: um disciplinador feroz e um tenaz combatente, com plenas condições de consolidar no Rio Grande o regime republicano e banir, definitivamente, as arreganhas do caudilhismo $^{105}$. Portanto, Floriano tinha pelo menos duas razões para sustentar o Castilhismo no Sul: 1) sua identificação com o autoritarismo progressista de Júlio de Castilhos e do PRR; 2) o temor de um retorno dos liberais ao poder, o que, além da volta de um grupo retrógrado ao comando de um estado de grande importância político-militar (fronteira com as nações do Prata), poderia significar uma ameaça para a própria sobrevivência do

Bagé. Este capitularia em 4 de julho diante de um cerco feito por tropas castilhistas em associação com o $30^{\circ}$ Batalhão de Infantaria do Exército, comandado pelo Coronel Artur Oscar, Silva Tavares vindo a imigrar com o grosso de suas tropas para o Uruguai. Os castilhistas teriam também de tomar à força Santana do Livramento e suportar, em 24 de junho, o bombardeio mal-sucedido de Porto Alegre pela canhoneira Marajó, comandada por oficial da Marinha ligado à dissidência republicana (ver Sérgio da Costa Franco, Júlio de Castilhos e sua época, pp. 124-125).

${ }_{102}$ Ver Sérgio da Costa Franco, Júlio de Castilhos e sua época, pp. 123-124.

${ }^{103}$ Edgard Carone, A República Velha (Evolução Política), p. 102, e Sérgio da Costa Franco, A Guerra Civil de 1893, p. 37.

${ }^{104}$ Ver Sérgio da Costa Franco, Júlio de Castilhos e sua época, pp. 127 e 129.

105 Sérgio da Costa Franco, Júlio de Castilhos e sua época, pp. 130-131. 
sistema presidencialista, ao qual Floriano se apegava (um regime parlamentarista a nível regional poderia, através de um "efeito dominó", levar à derrubada do regime presidencialista a nível federal).

Em 25 de janeiro de 1893, Júlio de Castilhos assume pela segunda vez o cargo de Presidente do Estado do Rio Grande do Sul ${ }^{106}$, e, oito dias depois, tropas federalistas estacionadas no Uruguai cruzam a fronteira sob o comando de Gumercindo Saraiva, dando início a uma nova fase do Governo Floriano.

C) A fase bélica (2 de fevereiro de 1893 a 10 de setembro de 1894).

Com a invasão, no dia 2 de fevereiro de 1893, do Rio Grande do Sul por uma tropa comandada pelo caudilho uruguaio-brasileiro Gumercindo Saraiva ${ }^{107}$, têm início a Revolução Federalista e uma nova fase no Governo Floriano, fase que durará um ano e meio e que chamaremos aqui de bélica pelo fato de as atividades do governo estarem voltadas quase que exclusivamente para 0 enfrentamento militar aos seus opositores. Como observa John Schulz ${ }^{108}$, a lei de 17 de dezembro ${ }^{109}$ assinalou o término do período de reformas de Floriano. A partir de fevereiro de 1893, o vice-presidente envolveu-se na guerra civil entre 0 PRR e os federalistas no Rio Grande do Sul. Esta luta consumiu uma parcela significativa da energia e do dinheiro do governo federal, deixando Floriano sem recursos suficientes para promover outras reformas ou controlar a inflação. Nesta fase, portanto, o Governo Floriano funcionará praticamente em função da guerra civil.

Não será nossa intenção, aqui neste item, fazer uma descrição da evolução militar das revoltas: além de não acrescentarmos nada aos manuais de história política e militar do período republicano brasileiro, estaremos fugindo da problemática do nosso trabalho. Abordaremos, no entanto, o tema das revoltas

\footnotetext{
${ }^{106}$ Sérgio da Costa Franco, A Guerra Civil de 1893, p. 41.

107 Glauco Carneiro, p. 79.

${ }^{108}$ O Exército na Política, p. 181.

${ }^{109} \mathrm{O}$ autor citado está se referindo ao já mencionado decreto de fusão do Banco do Brasil e do Banco da República.
} 
com o objetivo de interpretar o seu sentido, o seu significado, assim como o significado da resistência do governo frente a elas.

\section{A Revolução Federalista é fruto da tentativa, por parte de uma fração da elite monárquica desalojada em 15 de novembro de 1889, de retornar ao poder pela força frente à irredutibilidade do Castilhismo. Para Silveira Martins} e seus seguidores, a volta dos antigos liberais (e dos antigos conservadores agora seus aliados), ao comando do Rio Grande do Sul e a instauração da república unitária e parlamentar a nível nacional seriam fatores essenciais para a sobrevivência da pecuária gaúcha. Como observa Sandra Jatahy Pesavento ${ }^{110}$, o governo central brasileiro, já nas últimas décadas do Império, tinha tendência a dar preferência ao charque platino, mais barato e de melhor qualidade, o que fazia com que os representantes da pecuária gaúcha precisassem lutar dentro da arena política para garantir seus interesses e impedir que sua economia fosse à falência. O Parlamento seria o lugar propício para elites regionais de posição secundária dentro do contexto político nacional defenderem seus interesses, o que por sua vez seria mais difícil com o fortalecimento do Poder Executivo. E, como dissemos atrás, o unitarismo só poderia ter efeitos positivos sobre uma economia destinada a abastecer o mercado interno. Por outro lado, o Castilhismo, com seu discurso favorável à indústria, poderia significar, no futuro, uma maior taxação das atividades relacionadas à pecuária para o financiamento do setor industrial. Portanto, os federalistas procurarão retornar ao poder, levando sua luta às últimas conseqüências.

A guerra civil no Sul vai ter, durante o período florianista, duas grandes fases. A primeira tem início em fevereiro de 1893 e termina em julho do mesmo ano com o refúgio do grosso das tropas federalistas em território uruguaio, após a derrota para as forças legalistas na Batalha de Inhanduí. A segunda tem início com nova invasão do Rio Grande no mês seguinte e vai se caracterizar por uma ofensiva rebelde que extrapola os limites gaúchos, penetrando nos estados de Santa Catarina e Paraná, mas que, devido ao desgaste resultante dos confrontos

\footnotetext{
${ }^{110}$ História do Rio Grande do Sul, pp. 42-44.
} 
constantes com as forças legais, à derrota de Saldanha da Gama no Rio de Janeiro $^{111}$ e ao bloqueio militar paulista, vai desistir de seguir para o Norte e de fazer a junção com os revoltosos da Armada; ao regressar ao estado natal as forças rebeldes irão sofrer diversas derrotas, com a morte, inclusive, de Gumercindo Saraiva, e irão se refugiar, coluna após coluna, em terras platinas até 10 de setembro de $1894^{112}$.

Neste conflito, as forças federalistas, embora derrotando as tropas legais em diversos combates devido a investidas fulminantes de cavalaria ${ }^{113}$, nunca conseguirão fazer face à superioridade destas em homens e armamento: $A$ luta travou-se, inicialmente, e mesmo até o fim, entre forças de formação improvisada, e isto tanto de um lado como de outro. Mas as que apoiavam o governo dispunham naturalmente de unidades de linha, de melhor armamento e de mais abundantes recursos. Quando o Governo federal tomou a posição franca em apoio da situação castilhista, as chamadas colunas da legalidade passaram a ser formadas com forças do Exército ou destas com a Polícia Militar, completadas com guardas nacionais, e batalhões provisórios ou patriotas ${ }^{114}$. Como que seguindo os desígnios da coerência histórica, as forças do futuro, mais numerosas e melhor equipadas, derrotavam as forças do passado, militarmente arcaicas.

A Revolta da Armada terá, como embrião, o confronto político entre Floriano e seu ministro da Guerra.

Com a concentração progressiva do poder político nas mãos de Floriano, o número de deserções dentro do ministério da coalizão anti-deodorista aumentara.

\footnotetext{
${ }^{111}$ Veremos este ponto depois.

${ }^{112}$ Para maiores detalhes factuais sobre o conflito, ver Sérgio da Costa Franco, A Guerra Civil de 1893, pp. 43-56 e 59-89, e Edgard Carone, A República Velha (Evolução Política), pp. 107-112 e 116-122.

${ }^{113}$ Como afirma José Maria dos Santos (A Política Geral do Brasil, p. 264), a força federalista, quase sempre mal provida de armas de fogo e composta em grande parte de homens a cavalo, nunca deixou de ser uma tropa ligeira, à qual mais convinha a luta de movimento, em campanha rasa. A ação a que ela melhor se adaptava era o "entrevero" pelo qual, após algumas descargas iniciais, procurava intrepidamente neutralizar a sua inferioridade em fuzis e metralhadoras, pela intervenção das armas de choque.

${ }^{114}$ J. B. Magalhães, A Consolidação da República, pp. 76-77.
} 
Como vimos, já em fevereiro de 1892 o General José Simeão de Oliveira, Ministro da Guerra, se exonerava de seu cargo para ser substituído pelo General Francisco Antônio de Moura, e em junho do mesmo ano Antão de Faria, republicano dissidente do Rio Grande do Sul, deixava sua pasta em decorrência da aliança de Floriano com o Castilhismo. No mês seguinte, Rodrigues Alves, Ministro da Fazenda, discordando das posições de Floriano quanto à gestão da economia, se retirava do governo. Em abril de 1893 seria a vez de Custódio de Melo e Serzedelo Corrêa deixarem suas pastas e entrarem para a oposição, provocando grave crise no governo.

O baiano Custódio José de Melo era oficial de grande prestígio dentro de sua corporação. Tendo lutado na Guerra do Paraguai, onde fora oficial (e às vezes comandante) das canhoneiras Araguari, Ivaí e Felipe Camarão, dos encouraçados Silvado e Barroso e do monitor Pará (tendo tomado parte, dentro deste último, na famosa passagem da fortaleza paraguaia de Humaitá), fora diversas vezes elogiado por bravura e eficiência técnica. Depois da guerra, tendo feito longo curso na Europa, Custódio tivera papel importante na fiscalização da construção dos primeiros torpedos Whitehead encomendados pela Marinha Brasileira, na criação do Serviço das Torpedeiras e no estudo e instalação do armamento do encouraçado Aquidabã, assim como primeiro comandante do encouraçado Riachuelo, um dos primeiros navios que inauguraram no Brasil a moderna marinha mecanizada e metalizada. Quando da Proclamação da República, Custódio comandava o cruzador Almirante Barroso em viagem em torno do planeta, viagem durante a qual fora promovido ao Almirantado ${ }^{115}$. Como observa Hélio Leôncio Martins (p. 121), sem dúvida, Custódio José de Mello foi um dos mais brilhantes e eficientes oficiais de sua geração. Na guerra e na paz, o profissionalismo que 0 fazia sobressair foi provado e aprovado, sendo sempre figura de realce na corporação do mar. Possuía, entretanto, consciência muito viva deste seu valor, resultando daí personalidade individualista e orgulhosa, com grande suscetibilidade quando seu desempenho funcional não era reconhecido nos níveis

${ }^{115}$ Para todas essas informações, ver Hélio Leôncio Martins, pp. 118-119. 
que achava merecer, ou não ocupava posições com ele concordantes. O personalismo e o orgulho teriam desembocado em ambição política, o que explicaria, pelo menos em parte, suas atitudes políticas posteriores ao 15 de novembro de 1889. Com a República, Custódio era eleito deputado para a Assembléia Constituinte pelo Estado da Bahia, destacando-se por sua oposição a Deodoro, o que o levaria mais tarde a ser um dos cabeças da conspiração antideodorista que deporia o Marechal em 23 de novembro de 1891.

Custódio e seu amigo Serzedelo Corrêa ${ }^{116}$ deixavam suas pastas em 27 de abril de 1893, o primeiro alegando insatisfação para com o personalismo e a política pró-castilhista de Floriano no Rio Grande do Sul e o segundo se queixando dos gastos militares com a guerra civil no Sul, gastos que se deveriam ao apoio de Floriano ao líder do $P R R^{117}$. Custódio passara de fato a ver de forma hostil o Marechal a partir do momento em que este, sentindo-se suficientemente forte, dera início a uma política pessoal de cunho cesarista, começando a ofuscar a presença do Almirante dentro do governo: Com a mudança de comportamento de Floriano, depois de abril ${ }^{118}$, sentindo-se ele forte, apoiado pelo Exército e pelo Congresso, os atritos com seu ministro de maior prestígio amiudaram-se. Era o encontro de duas personalidades psicologicamente opostas. Às declarações diretas, orgulhosas, altivas do almirante respondiam gestos e posições dúbias, silêncios e ações tortuosas, não frutos de um caráter fraco e hesitante, mas sim de

\footnotetext{
116 Serzedelo, integrante da força insurrecional de Deodoro e Benjamin Constant em 15 de novembro de 1889, tinha, embora fosse oficial-engenheiro do Exército, muitos contatos na Marinha, incluindo-se aí Frederico de Lorena, Eduardo Wandenkolk e o próprio Custódio, que sob a ditadura deodorista o encarregara de sublevar a Escola Militar, o que seria feito com sucesso em 23 de novembro (ver Eurico Serzedello Machado, pp. 23-24 e 32).

117 José Maria Bello, pp. 106-107. Como vimos, Serzedelo era um representante da oficialidade positivista do Exército, que, depois da morte de seu líder Benjamin Constant, aderira ao Florianismo pelo fato deste reunir algumas características do republicanismo positivista, como o progressismo e o autoritarismo. Mas, este grupo não poderia ser considerado como representando a típica oficialidade florianista, que estaria mais próxima do tipo troupier (exemplos de Moreira César, Artur Oscar, Francisco de Moura e Argolo). Serzedelo, muito provavelmente discordando do militarismo crescente do Governo Floriano e só enxergando os problemas pelo viés econômico (o equilíbrio do Tesouro), não percebia a importância da aliança com os castilhistas no Sul como forma de se evitar a retomada do poder, dentro do regime republicano, pela antiga elite monárquica.

${ }_{118} \mathrm{O}$ autor citado está se referindo ao mês de abril de 1892, quando o governo obteve sua vitória sobre os revoltosos deodoristas.
} 
um tipo de manobra que não perdia de vista, com firmeza, os objetivos a serem alcançados, e dos quais ele, Floriano, não se afastava ${ }^{119}$. Para dar uma coloração ideológica para suas ambições políticas, Custódio vai se colocar como defensor da Constituição de 24 de fevereiro (nosso lugar era de vigilante à porta da Constituição ${ }^{120}$, que teria sido violada primeiramente por Deodoro e posteriormente por Floriano, com seu governo unipessoal e sua aliança com o antigo deodorista Júlio de Castilhos. Com a saída de seu incômodo ministro da Marinha, Floriano rompia definitivamente com a coalizão de 23 de novembro.

Embora, ao sair do ministério, Custódio tivesse iniciado, usando seu prestígio, uma "greve de almirantes" que faria com que muitos deles recusassem o convite para ocupar a pasta da Marinha ${ }^{121}$, Floriano conseguiria, já em 30 de abril, nomear o Contra-Almirante Felipe Firmino Rodrigues Chaves ${ }^{122}$; para a pasta da Fazenda, era nomeado Felisbelo Freire, um republicano de Sergipe que fora o primeiro governador provisório de seu estado após a Proclamação da República e defensor do Governo Floriano no Congresso durante a crise política de abril $1892^{123}$.

A primeira tentativa de ação conjunta entre a oficialidade anti-florianista da Marinha e os rebeldes federalistas vai se dar com Eduardo Wandenkolk, em julho de 1893. Este almirante, que mais de um ano antes participara do ciclo de revoltas deodoristas, apropria-se no dia 6, em Buenos Aires, do navio mercante Júpiter, carregando-o de armas e munições, e planeja atacar a cidade do Rio Grande em conjunto com a coluna de Gumercindo Saraiva, que viria por terra. A não-aparição desta quando Wandenkolk chegava diante da barra do Rio Grande faz o Almirante abortar o plano, sendo ele capturado pelo cruzador República que vinha do Rio de Janeiro em sua perseguição, e preso na Fortaleza de Santa Cruz, de onde só sairá com o término da Revolta da Armada ${ }^{124}$. A prisão de Wandenkolk numa

\footnotetext{
${ }^{119}$ Hélio Leôncio Martins, p. 100.

${ }^{120}$ Almirante Custódio José de Mello, $1^{\circ}$ tomo, p. 285.

121 John Schulz, O Exército na Política, p. 186.

${ }^{122}$ Roberto Macedo, p. 125.

${ }^{123}$ Roberto Macedo, p. 88.

${ }^{124}$ Ver Edgard Carone, A República Velha (Evolução Política), p. 115, e Glauco Carneiro, p. 81.
} 
fortaleza sob jurisdição do Exército vai parecer uma afronta à Marinha ${ }^{125}$, e vai servir de preâmbulo à Revolta da Armada; como observa Hélio Leôncio Martins (pp. 151-152), o autoritarismo militar exercido pelo Exército, exacerbado por Floriano para sua própria segurança, despertava nos quadros da Armada sentimento de inferioridade, de secundarismo, que tivera um interregno de esperança com a revolta de 23 de novembro de 1891 e o posicionamento do Almirante Custódio José de Mello como poderoso ministro da Marinha, influindo em todo o cenário nacional. Essas ilusões desapareceram com a saída de Custódio do ministério. Custódio de Melo, por sua vez, irá aproveitar este sentimento de revolta de cunho corporativo para se por à frente de um movimento "libertário" visando derrubar Floriano, embora sua motivação não fosse corporativa e sim política: por exemplo, durante as revoltas deodoristas, Custódio, aproveitando-se de sua posição de Ministro da Marinha, passara a atacar, através de críticas, oficiais como Saldanha da Gama e o próprio Wandenkolk, figuras de prestígio que poderiam ofuscar sua imagem dentro da Marinha ${ }^{126}$ (podemos inclusive perceber na ação de Custódio uma tendência ao Cesarismo, na medida em que este oficial, da mesma forma que Floriano, tendia a se colocar acima de sua própria corporação).

Contando com o apoio de antigos elementos deodoristas como o Conde de Leopoldina $^{127}$, Rui Barbosa, J. J. Seabra, Américo Brasiliense, José Mariano, Francisco Portela ${ }^{128}$ e José Clarindo de Queiroz, e de outras personalidades do mundo civil e militar, como Sólon Ribeiro ${ }^{129}$, Serzedelo Corrêa e José do

\footnotetext{
${ }^{125}$ Edgard Carone, A República Velha (Evolução Política), p. 115.

${ }^{126}$ Edgard Carone, A República Velha (Evolução Política), p. 88.

127 O Conde de Leopoldina, grande banqueiro do Encilhamento, será um dos maiores responsáveis pelos gastos da revolta, garantindo ou pagando grande parte das despesas em armamentos e encarregando-se de entrar em contato com outros elementos dispostos a contribuir no financiamento (Edgard Carone, A República Velha (Evolução Política), p. 120).

${ }_{128}$ Francisco Portela era o governador deodorista do Estado do Rio de Janeiro deposto em dezembro de 1891 (Edgard Carone, A República Velha (Evolução Política), pp. 78-79).

${ }^{129} \mathrm{O}$ General Sólon Ribeiro, que fora um dos principais personagens da conspiração republicana e um dos integrantes da força insurrecional de 15 de novembro de 1889, estava, nas vésperas da Revolta da Armada, articulando com a oposição paulista que girava em torno de Américo Brasiliense (Edgard Carone, A República Velha (Evolução Política), p. 120).
} 
Patrocínio $^{130}$, Custódio de Melo, de dentro do encouraçado Aquidabã, lidera uma esquadra rebelde composta de dezesseis navios de guerra e dezoito navios mercantes $^{131}$, que na manhã de 6 de setembro de 1893 surge na Baía da Guanabara ostentando a bandeira branca, símbolo da rebelião ${ }^{132}$. No dia seguinte é lançado o manifesto dos revoltosos, onde Custódio louva o movimento armado que derrubou a ditadura deodorista em 23 de novembro de 1891, fala de sua própria falta de ambições políticas, de seu apego às liberdades democráticas, ao regime republicano e à Constituição de 24 de fevereiro, condena o autoritarismo florianista, seu militarismo, sua política no Sul e os altos gastos governamentais ${ }^{133}$.

Custódio de Melo estaria se colocando, portanto, como um republicano liberal-democrata em conflito com o cesarismo florianista. No entanto, como observa José Maria dos Santos ${ }^{134}$, a ação do Almirante, por se justificar essencialmente na defesa da Constituição, carecia, diferentemente dos federalistas gaúchos, de um projeto político definido. Sendo possível, e até mesmo provável, que Custódio aspirasse a ser sucessor de Floriano na Presidência da República $^{135}$, a limitada componente ideológica da Revolta de 6 de setembro pareceria mais uma fachada para as ambições políticas de seu líder. Por outro lado, o financiamento e o apoio à revolta por deodoristas e representantes da burguesia bancária do Rio de Janeiro nos faz supor que Custódio, assumidamente republicano e anti-deodorista, mas ao mesmo tempo ambicioso e sem possuir um projeto nítido para o país, seria um agente,

\footnotetext{
${ }^{130}$ Para o envolvimento de todos esses nomes com a revolta de Custódio de Melo, ver John Schulz (O Exército na Política, p. 188) e Edgard Carone (A República Velha (Evolução Política), pp. 121-122).

${ }^{131}$ Edgard Carone, A República Velha (Evolução Política), p. 125. Segundo Hélio Leôncio Martins (pp. 163-164), Custódio dispunha, além do Aquidabã, de apenas mais quatro navios de guerra capazes de se movimentarem com seus próprios meios: o pequeno mas bem artilhado cruzador República, o navio de madeira de propulsão mista Trajano e as torpedeiras Marcílio Dias e Araguari, estas últimas com limitações para operar em alto-mar. Os melhores dos dezoito navios mercantes e rebocadores apoderados pelos revoltosos eram pertencentes à Companhia Frigorífica e, além de velozes e aptos para receberem armamento, tinham seus porões repletos de gêneros de toda espécie.

${ }^{132}$ Hélio Leôncio Martins, pp. 160-162.

${ }^{133}$ Ver Edgard Carone, A Primeira República (Texto e Contexto), pp. 26-28.

${ }^{134}$ A Política Geral do Brasil, p. 248.

135 José Maria dos Santos, A Política Geral do Brasil, p. 248.
} 


\section{consciente ou não, de uma fração da antiga elite imperial que se apoiara anteriormente no Deodorismo.}

A Revolta da Armada, que vai marcar o confronto entre uma esquadra rebelde que detém o controle da Baía da Guanabara e da maior parte dos navios brasileiros $^{136}$ e um governo que conta com o apoio de ampla maioria do Exército ${ }^{137}$ e da maior parte da oficialidade da Marinha ${ }^{138}$, além do apoio do Congresso, do PRP e dos governos estaduais ${ }^{139}$, vai se caracterizar por um duelo inexpressivo entre os navios revoltosos e as fortalezas governamentais, chegando a haver, em alguns momentos no entanto, bombardeio da cidade do Rio de Janeiro e vítimas civis $^{140}$; a partir de 5 de outubro este duelo de artilharia passará a ser monitorado pelas forças navais estrangeiras estacionadas no Rio de Janeiro ${ }^{141}$.

${ }_{136}$ Edgard Carone, A República Velha (Evolução Política), p. 125.
137 John Schulz, O Exército na Política, p. 189.
138 Como afirma Hélio Leôncio Martins (pp. 158-159), também não contavam os insurretos com a
totalidade da corporação, dificilmente podendo ser chamada a revolta pelo nome que ficou na
História - "da Armada". Nela tomaram parte, como revoltosos, apenas 139 oficiais dos diversos
corpos (Armada, Saúde, Maquinistas, Comissários), alguns da reserva, e 53 foram mantidos
presos pelo governo. Incluía, inicialmente, um único oficial-general (Custódio) e, depois, Saldanha,
dois capitães-de-mar-e-guerra (Frederico de Lorena e Eliezer Tavares) e um capitão-de-fragata
(Alexandrino de Alencar). Os outros eram oficiais mais baixos. Compondo-se os quadros da
Armada, na época, de 597 oficiais, apenas dois quintos revoltaram-se. Os restantes permaneceram
neutros, ocuparam funçóes administrativas ou, convictos de que Floriano representava a
República, puseram-se a seu lado, guarnecendo inclusive os navios adquiridos pelo governo. ${ }_{139}$ Ver John Schulz, O Exército na Política, p. 189, e Edgard Carone, A República Velha (Evolução Política), p. 124. Temos, no entanto, como "quase-exceção", o caso de Pernambuco, onde o Governador, Capitão Alexandre Barbosa Lima, oficial positivista do Exército que fora colocado por Floriano na Presidência do Estado, adere à oposição anti-florianista local, formada por lideranças deodoristas como José Mariano (e seu Partido Autonomista) e por republicanos históricos como Aníbal Falcão e Martins Júnior; porém, a fidelidade do General Leite de Castro, Comandante do $2^{\circ}$ Distrito Militar sediado em Recife, ao Governo Floriano faz Barbosa Lima recuar e se colocar novamente ao lado do Marechal (para maiores detalhes ver Edgar Carone, A República Velha (Evolução Política), p. 130, e J. Gonçalves Maia, pp. 43-68).

${ }^{140}$ Ver Hélio Leôncio Martins, pp. 179 e 185.

${ }^{141}$ Através do Acordo de 5 de outubro, mediado pelas potências estrangeiras sob a liderança da Inglaterra, a esquadra rebelde se comprometia a não bombardear o Rio de Janeiro enquanto que 0 governo por sua vez se comprometia a retirar os canhões instalados nos morros (para maiores detalhes ver Edgard Carone, A República Velha (Evolução Política), pp. 128-129 e Hélio Leôncio Martins, pp. 197-203). Os representantes das potências estrangeiras tinham, como pretexto para monitorar o duelo de artilharia entre os navios revoltosos e as fortalezas governamentais, a salvaguarda da vida e das atividades comerciais de seus súditos residentes na Capital Federal (José Maria Bello, p. 117, e Hélio Leôncio Martins, p. 197). No entanto, o fato de Floriano ter se beneficiado da intervenção estrangeira, já que a esquadra rebelde estava impedida de qualquer violência contra a cidade e limitada a um duelo diário com as fortalezas da barra (José Maria Bello, p. 117) nos faz supor que as potências estrangeiras, em especial a Inglaterra, tinham naquele momento interesse na permanência de Floriano no comando do país, ponto do qual trataremos mais adiante. 
O marasmo da Revolta da Armada será interrompido, em 7 de dezembro de 1893, com a adesão do Almirante Saldanha da Gama ${ }^{142}$. Saldanha da Gama, que depois da queda do Deodorismo fora nomeado, devido a seu prestígio, diretor da Escola Naval, recusara-se inicialmente a participar da Revolta da Armada, chegando a chamar seu rival Custódio de Melo de "fabricante de legalidade"143; a principal razão para sua atitude é que, prevendo um desfecho funesto para a esquadra rebelde, planejava manter a Escola Naval e o Corpo de Marinheiros neutros, conservando oficiais e marinheiros para a Marinha que renasceria depois da tempestade política e militar ${ }^{144}$. No entanto, a pressão de seus comandados desejosos de participar da revolta e sua própria aversão a Floriano e ao regime republicano falariam mais forte, levando-o a romper com sua anterior posição de neutralidade ${ }^{145}$.

Enquanto Custódio de Melo, embarcado no Aquidabã e acompanhado pelo cruzador-auxiliar Esperança, abandona, sob o fogo concentrado das fortalezas governamentais, a Baía da Guanabara para reforçar a esquadra rebelde em Santa Catarina $^{146}$, Saldanha assume o comando no Rio de Janeiro ${ }^{147}$. Em manifesto publicado na imprensa no dia 9 de dezembro, o novo comandante justifica sua adesão afirmando que, embora avesso por princípio e por instinto a toda idéia de revolta, pega em armas para combater o militarismo e o jacobinismo, e para ajudar os federalistas gaúchos, que segundo ele estariam lutando pela mesma causa. Por outro lado, ele faz esta colocação extremamente infeliz: A lógica assim como a justiça dos fatos autorizaria que se procurasse à força das armas repor o governo do Brasil onde estava a 15 de novembro de 1889, quando num momento de

\footnotetext{
${ }^{142}$ Hélio Leôncio Martins, p. 256.

${ }^{143}$ Hélio Leôncio Martins, p. 129.

${ }^{144}$ Hélio Leôncio Martins, p. 129.

${ }^{145}$ Ver Hélio Leôncio Martins, pp. 233-234.

${ }^{146}$ Ainda em setembro Custódio incumbira Frederico de Lorena, um dos oficiais revoltosos, de comandar uma pequena força naval composta pelo cruzador República, o transporte Palas e a torpedeira Marcílio Dias com o objetivo de tomar o porto de Santos, no litoral paulista, arregimentar revoltosos civis e militares e subir a serra em direção a São Paulo, para dali marchar para a Capital Federal (Carlos Humberto Corrêa, p. 57). No entanto, devido à impossibilidade técnica da força naval desembarcar em Santos, Lorena partira em direção ao Sul, decidindo, por conta própria, tomar Desterro, capital do Estado de Santa Catarina, fazendo-o em 2 de outubro com a conivência das autoridades locais (para maiores detalhes ver mesmo autor, pp. 38-56).

${ }^{147}$ Hélio Leôncio Martins, pp. 255-256.
} 
surpresa e estupefação nacional ele foi conquistado por uma sedição militar, de que o atual governo não é senão uma continuação. O respeito, porém, que se deve à vontade nacional livremente manifestada aconselha que ela mesma escolha solenemente e sob sua responsabilidade a forma de instituições que deseja envolver os seus gloriosos destinos ${ }^{148}$. Este apreço confesso pelo regime deposto vai trazer sérios problemas aos revoltosos, que de defensores da Constituição de 24 de fevereiro passam repentinamente a "chouans tupiniquins", a restauradores do Trono: como diz José Maria Bello (p. 117), a suspeita de monarquismo que a adesão posterior de Saldanha da Gama agravaria, leva os republicanos, inclusive os que the eram adversos, a se congregarem em torno de Floriano. A partir daí podemos dizer que o anti-florianismo assume um tripla face, que José Maria dos Santos ${ }^{149}$, embora não escondendo suas simpatias pelos federalistas gaúchos, retrata bem: O movimento revolucionário no Brasil ficou portanto tripartido em três programas diversos e francamente antagônicos. De um lado, os liberais do Rio Grande do Sul, com a sua grande idéia da volta às nossas antigas liberdades políticas, dentro do regime republicano; e outro, 0 melhor emprego da constituição de 24 de fevereiro, confiada a novos e mais fiéis executores, segundo Custódio de Melo; e, finalmente, o processo plebiscitário lançado à última hora pelo Almirante Saldanha da Gama. Saldanha acaba desmascarando, embora de forma involuntária, a componente reacionária do anti-florianismo ao dar um conteúdo restaurador para a Revolta da Armada e ao fazer crer que a antiga elite imperial desejasse restaurar o Trono, quando que seu real objetivo era o de se apoderar do aparelho de Estado republicano. 0 monarquismo romântico de Saldanha da Gama, que definitivamente nada tinha a ver com o projeto da burguesia bancária do Rio de Janeiro, das lideranças regionais ligadas ao extinto Deodorismo e da elite pecuarista gaúcha, acabaria se transformando numa faca de dois gumes. Se, por um lado, os rebeldes ganhavam com a adesão de um oficial de prestígio, por outro perdiam com a nova conotação abertamente reacionária da revolta: o almirante deu ao adversário um elemento

\footnotetext{
${ }^{148}$ Ver Edgard Carone, A Primeira República (Texto e Contexto), pp. 28-30.

${ }^{149}$ A Política Geral do Brasil, pp. 253-254.
} 
precioso para martelar que a revolução visava, sobretudo, o regime republicano. $O$ levante da Esquadra perdia, pois, o caráter de uma reação democrática contra a tirania caudilhesca e militarista para revestir-se de um cunho ideológico que vinha favorecer os dominadores, dadas as condições do meio e do tempo ${ }^{150}$. Embora não houvesse possibilidade alguma, pelas razões expostas no início do capítulo II, de se restaurar o Trono, a conotação monárquica do manifesto de Saldanha traria portanto a Floriano a fama de Consolidador da República.

Com a capitulação dos revoltosos em 12 de março de 1894, mês seguinte ao sangrento Combate da Ponta da Armação, em Niterói, onde os rebeldes eram derrotados pelas forças legalistas do General Francisco de Paula Argolo ${ }^{151}$, as tropas do governo estavam liberadas para o enfrentamento exclusivo aos federalistas ${ }^{152}$ que, situados no Paraná, iniciavam retorno para o Sul para serem posteriormente derrotados e se internarem na Argentina e no Uruguai.

Podemos então dizer que em 10 de setembro de 1894 encerra-se a fase bélica do Governo Floriano, a fase em que o neo-monarquismo foi derrotado no campo de batalha. Com a vitória militar do Florianismo, as frações da antiga elite monárquica desejosas de se apoderarem do aparelho de Estado republicano capitulavam de vez ${ }^{153}$. $O$ fracasso do movimento armado antiflorianista (e anti-castilhista) se deve, além de sua inferioridade técnica (em homens, armamento e limites de campo de ação), à inútil tentativa, mesmo que pela força, de uma elite já superada e ligada ao antigo Estado escravista, de retornar ao poder após a própria extinção do escravismo. 0 antiflorianismo pecou sobretudo por querer ir contra o sentido da História.

\footnotetext{
${ }^{150}$ Pedro Lafayette (citado por Maria de Lourdes Mônaco Janotti, pp. 71-72).

151 Ver Hélio Leôncio Martins, pp. 298-304.

152 José Maria Bello, p. 125.

${ }^{153}$ Embora os federalistas voltassem a invadir o Rio Grande do Sul no mesmo mês de setembro, como veremos no próximo item, a revolução já estava praticamente derrotada.
} 


\section{D) O Florianismo, o PRP e a questão sucessória.}

\section{1) $O$ continuísmo.}

Muito se tem especulado sobre as reais intenções de Floriano quanto à questão sucessória. Autores apologistas do Marechal de Ferro ${ }^{154}$ sustentam a tese de que este transmitira o poder a seu sucessor, Prudente de Moraes, por respeito à legalidade e que, inclusive, teria se ausentado da cerimônia de transmissão do cargo para conter o ímpeto golpista de seus seguidores militares. No entanto, é para nós difícil de acreditar que um Chefe de Estado, que tanto empenho demonstrou em consolidar seu poder político e em reprimir os movimentos armados contra sua autoridade, tivesse, após todo o sangue derramado, como único objetivo assegurar a legalidade republicana, principalmente quando se trata de um líder de tendências cesaristas e com um projeto de desenvolvimento bem definido para o país ${ }^{155}$. Floriano, a nosso ver, teve de entregar o cargo a um sucessor que ele não apreciava devido a obstáculos concretos à sua própria permanência no poder; é o que veremos a seguir.

\section{2) Uma tática vitoriosa.}

Para entendermos o contexto da luta pela hegemonia no período final do mandato de Floriano Peixoto, será necessário fazer um pequeno histórico da postura política do PRP entre 1891 e 1894, na medida em que é este grupo que

\footnotetext{
${ }^{154}$ Ver, por exemplo, Cyro Silva (pp. 197-199), Salm de Miranda (pp. 303-310) e Sylvio Peixoto, (pp. 261-269).

${ }^{55}$ No momento em que se desenhavam, já no ano de 1893, as primeiras escaramuças em torno da sucessão presidencial, e que o nome de Prudente de Moraes era o mais cotado, Floriano teria dito a Francisco Glicério: Não há de botar sangue; é verdade que o Prudente tem relevantes serviços prestados, é histórico e merece tudo da República, mas não presidir os seus destinos no futuro quadriênio, porque prevejo perseguições aos nossos amigos. Até você também não será poupado, há de sofrer bastante. Mais tarde me dirá se tenho ou não razão; mas fique certo de que, qualquer que seja o eleito e proclamado pelo Congresso, eu empossarei no poder (Sylvio Peixoto, pp. 266-267). Esta afirmação, apesar de usada como argumento para os defensores da tese do "Floriano legalista", contém um sentido dúbio, já que a aversão do Marechal a Prudente é explícita e, sendo seu interlocutor um integrante do PRP, ele de forma alguma poderia revelar ambições golpistas.
} 
vai se aproveitar do confronto entre as diversas facções políticas e militares para se instalar definitivamente no poder.

Com a implantação da República, a estratégia inicial dos republicanos paulistas fora de ao mesmo tempo consolidar seu poder a nível regional e intervir na política federal para garantir a implantação de reformas que beneficiassem a elite cafeeira paulista ${ }^{156}$ : em São Paulo, com a queda do regime monárquico o PRP subia ao poder ${ }^{157}$, enquanto que no Governo Federal, Campos Sales emitia, como vimos, vários decretos, como os que estabeleciam a separação de Igreja e Estado, a dualidade de juízes, etc. A própria promulgação da Constituição de 24 de fevereiro era uma grande vitória para o PRP, na medida em que, além de implantar a República Federativa, consolidava as reformas de Campos Sales. Mas, como vimos também, o conservadorismo de Deodoro quase pôs tudo a perder, levando à derrubada do próprio Deodorismo.

Com a ascensão de Floriano, o PRP voltava ao poder através da nomeação de Rodrigues Alves para o Ministério da Fazenda, ao mesmo tempo em que o governador deodorista de São Paulo, Américo Brasiliense, era derrubado. No entanto, o programa industrialista de Floriano levaria à demissão de Rodrigues Alves. Essa orientação industrializante de Marechal, oposta ao projeto da elite cafeeira paulista, por sua vez vinculado ao modelo agro-exportador, seria razão suficiente para o PRP se colocar contra o governo e procurar promover, junto com a oposição, a derrubada deste. Porém, ele continuará a prestar apoio a Floriano: durante a Revolta da Armada e a Revolução Federalista, o Governo de São Paulo fornecerá, ao Governo Federal, dinheiro, homens e armamento ${ }^{158}$.

O que teria levado a agremiação política representante de uma elite agroexportadora a se aliar com um governo militar nacionalista voltado para a indústria? Esta aliança será puramente tática, mas ela não acontecerá por acaso. Primeiramente, os republicanos paulistas perceberam que, num período que se caracterizava por uma luta entre várias facções militares, tanto no Exército como

\footnotetext{
${ }^{156}$ Eduardo Kugelmas, p. 48.

${ }^{157}$ Ver José Ênio Casalecchi, p. 63.

158 June Hahner, pp. 140-141.
} 
na Marinha (florianistas, deodoristas, seguidores de Custódio de Melo, seguidores de Saldanha da Gama, etc.), a derrubada do governo militar de Floriano por uma insurreição militar só faria prolongar o militarismo e adiar a tomada do poder federal pelo $\mathrm{PRP}^{159}$, e que, ao contrário, a vitória final do Florianismo sobre as facções militares rivais acabaria por abrir o caminho para o governo civil com 0 desgaste final dos florianistas. Por outro lado, o Florianismo era útil ao PRP, na medida em que seu autoritarismo militar progressista entrava em choque com grupos conservadores que poderiam trazer embaraços para a futura dominação paulista, grupos que os paulistas ainda não tinham condições de combater por serem apenas uma força regional. Primeiramente, o Governo Floriano usará a força para reprimir os deodoristas. Depois, enfrentará militarmente a Revolução Federalista, cujo líder político, Silveira Martins, além de representar a velha elite imperial, defendia a implantação de uma república parlamentar e centralizada, o que em si era uma dupla ameaça aos interesses paulistas: por um lado era uma ameaça à permanência do sistema federativo, que como vimos no capítulo II era imprescindível para um maior desenvolvimento da economia cafeeira, e por outro era uma ameaça à sobrevivência do Presidencialismo, que garantiria, após a tomada do poder pelo PRP, a supremacia deste sem a presença significativa de grupos de pressão antagônicos. E, finalmente, combaterá a Revolta da Armada, por trás da qual encontramos novamente a burguesia bancária do Rio de Janeiro. O PRP, ainda sem forças suficientes para enfrentar a antiga elite imperial, precisava se apoiar num governo ao mesmo tempo autoritário e progressista, que tivesse uma ideologia agressiva de combate aos remanescentes do "antigo regime", assim como o poder de arregimentação de forças militares para a luta política, poder de arregimentação que se devia ao fato de Floriano ser um alto oficial do Exército.

Embora Francisco Glicério tenha sido o principal articulador do apoio parlamentar ao Governo Floriano ${ }^{160}$, é sobretudo a Bernardino de Campos, um dos mais clarividentes líderes do PRP, que se deve a aliança deste partido com o

\footnotetext{
159 June Hahner, pp. 138-139.

160 José Maria Bello, pp. 130-131.
} 
Marechal. Enquanto que, quando no mês de março de 1892 passara-se a exigir novas eleições presidenciais, republicanos paulistas como Campos Sales e Rodrigues Alves pareciam aderir à campanha oposicionista temendo o continuísmo de Floriano, Bernardino de Campos conseguiria convencer o PRP a dar seu apoio ao governo ${ }^{161}$. Bernardino, como típico republicano paulista, não tinha simpatias por governos militares, mas entendia que a saída de Floriano significaria a subversão da ordem material em todos os estados $^{162}$, e, conseqüentemente, o estabelecimento da anarquia e uma possível volta do Deodorismo. Tendo o Exército preenchido o vácuo de poder resultante da queda do Império, fatalmente o primeiro quatriênio presidencial da República seria ocupado por um presidente militar, e a permanência de Floriano, vice e portanto sucessor natural do já deposto Deodoro, parecia ser "dos males o menor"163. José Maria dos Santos ${ }^{164}$, ao comentar o apoio de Bernardino de Campos a Floriano, afirma que a política florianista, até o termo do primeiro quatriênio presidencial em 15 de novembro de 1894, foi toda o resultado de um pacto de aliança, tratado entre aqueles dois homens naquele instante decisivo. Mas, como bem lembra o mesmo autor $^{165}$, para Bernardino este apoio só deveria permanecer até 15 de novembro de 1894, quando então o PRP tomaria o poder pela via eleitoral.

A aliança entre o Florianismo e o PRP explica a nosso ver o apoio, mesmo que ambíguo, da esquadra inglesa ao Governo Floriano durante a Revolta da Armada. Como observa Renato M. Perissinotto (p.168), o capital estrangeiro, e sobretudo inglês, já se instalara no esquema de comercialização do café brasileiro. Sendo o capital inglês um aliado econômico da elite cafeeira paulista e, portanto, do PRP, a aliança provisória deste com o Florianismo teria levado a coroa inglesa a apoiar, embora discretamente, este último. Mesmo que a imprensa inglesa fosse em geral simpática à Revolta da Armada, acusando Floriano de exercer um despotismo militar até então desconhecido e defendendo a volta do

\footnotetext{
${ }^{161}$ José Maria dos Santos, Bernardino de Campos e o Partido Republicano Paulista, p. 255.

162 José Maria dos Santos, Bernardino de Campos e o Partido Republicano Paulista, pp. 255256.

163 José Maria dos Santos, Bernardino de Campos e o Partido Republicano Paulista, pp. 255256.

${ }^{164}$ Bernardino de Campos e o Partido Republicano Paulista, p. 250.

${ }^{165}$ Bernardino de Campos e o Partido Republicano Paulista, p. 256.
} 
regime monárquico no Brasil ${ }^{166}$, o governo inglês vai, através da ação de sua esquadra estacionada no Rio de Janeiro, reduzir o já limitado campo de ação dos revoltosos ao proibir o bombardeio da Capital Federal. Logicamente, este apoio é bem fraco se o compararmos ao apoio norte-americano ${ }^{167}$, que não se baseava, pelo menos não exclusivamente, em vantagens econômicas, tratando-se essencialmente de um apoio político: além da importância da Doutrina Monroe, que defendia a "América para os americanos" e que não poderia tolerar uma volta do Império, uma herança européia num país de proporções gigantescas como o Brasil, os norte-americanos podem ter visto no Florianismo um similar do espírito progressista ianque em luta contra grupos retrógrados e pertencentes a uma outra época, Floriano aparecendo aqui como versão tupiniquim do General Ulysses S. Grant.

\section{3) A queda do Florianismo.}

De qualquer forma, depois de superada a crise política, não interessava ao PRP se consolidar no poder estadual ao mesmo tempo em que se mantinha um governo militar nacionalista a nível federal. Uma liderança de tipo cesarista no Governo Federal poderia significar uma intervenção constante nos estados e o conseqüente risco de desalojamento do PRP do Governo Estadual $^{168}$, além de gerar uma instabilidade política que assustaria os

\footnotetext{
${ }^{166}$ Sérgio Corrêa da Costa, pp. 146-147.

${ }^{167}$ Durante a Revolta da Armada, através de seu ministro em Washington, Salvador de Mendonça, o governo brasileiro conseguira obter o apoio político dos EUA, utilizando, como argumento, a Doutrina Monroe e a defesa da supremacia norte-americana no continente, supremacia que estaria ameaçada por uma revolta monarquista pró-européia e apoiada pelos Rothschild. O governo norteamericano enviara o Contra-Almirante A. E. K. Benham para chefiar a esquadra de seu país no Rio de Janeiro; este oficial quase entraria em combate com os revoltosos entre 27 e 29 de janeiro de 1894, fazendo estes últimos recuarem e perderem o controle sobre os navios estrangeiros que entravam na Baía da Guanabara (ver Sérgio Corrêa da Costa, pp. 123-131 e Edgard Carone, A República Velha (Evolução Política), pp. 139-141).

168 Embora durante o seu governo Floriano tivesse respeitado a autonomia de São Paulo, o episódio das deposições estaduais depois da queda do Deodorismo e o fato de o Exército ser uma corporação "nacional" e de estrutura centralizada nos leva a crer que seu governo ditatorial teria, caso tivesse sido implantado, forte tendência à centralização política. Aliás, como bem observa Wilma Peres Costa (p. 301), mais complexa era a relação dos militares com o outro eixo do movimento republicano, o federalismo. Embora não fossem seus adversários de princípio durante os anos 70 e 80, quando a bandeira de ampliação da autonomia das províncias empolgava liberais
} 
investidores e credores estrangeiros ${ }^{169}$, dos quais dependia fortemente a elite cafeeira paulista $^{170}$. Além do mais, a postura anti-européia do Governo Floriano e a xenofobia de muitos de seus seguidores contra imigrantes europeus, sobretudo os de origem portuguesa, poderiam transformar o Brasil num país desfavorável à vinda em massa de colonos para a lavoura cafeeira. E a ênfase do Marechal na indústria poderia significar uma maior taxação do setor agro-exportador para o financiamento daquela. Portanto, se o PRP teve de combater o Governo Deodoro por este fazer a política econômica da plutocracia financeira do Império, ele terá de se livrar do Florianismo por todos os "inconvenientes" que um governo militar nacionalista poderia trazer a uma economia agro-exportadora. O PRP, para atingir seus objetivos regionais, terá de assumir o controle da política federal.

Após os sangrentos episódios que resultaram na capitulação dos revoltosos da Armada e no exílio dos rebeldes federalistas nos países platinos, o PRP se apronta para assumir o poder federal. Eleito Presidente da República em 1ํ de março de $1894^{171}$, quando o Brasil estava em plena guerra civil, Prudente de Moraes se prepara para assumir. Embora os florianistas planejassem permanecer no comando do país, eles não terão forças suficientes para dar um golpe de Estado e implantar a ditadura. Isto se dará pelas seguintes razões:

e republicanos, os militares, vistos em sua especificidade institucional, nada tinham em comum com as teses federalistas e tudo farão para neutralizar seus excessos na Constituinte de 1891. Pode-se dizer, nesse sentido, que a posição dos militares é oposta à das oligarquias agrárias regionais, e parte de um diagnóstico também oposto das mazelas do Império. Se, para as oligarquias agrárias, o Estado imperial era excessivamente centralizado, e até mesmo tirânico, é precisamente a sua tibieza e sua incapacidade de concentrar a violência e a autoridade que afeta os militares profissionais.

${ }^{169}$ Em princípios de 1890, Campos Sales dizia: Nossos credores, aliás não exigem de nós senão uma administração honesta e econômica, ao lado de uma política tão previdente que não possa produzir o desmembramento, ou antes que possa garantir a nossa integridade territorial (ver Eduardo Kugelmas, p. 55).

${ }^{170}$ Ver Renato M. Perissinotto (cap.3), onde é estudada a forte presença, já na década de 1890, do capital estrangeiro, sobretudo inglês, na economia cafeeira paulista, assim como a importância que terão os empréstimos dos banqueiros ingleses e europeus em geral nos esquemas de valorização do café no início do século XX.

${ }^{171}$ Edgard Carone, A República Velha (Evolução Política), p. 148. Embora Floriano preferisse, para a candidatura presidencial, o nome de Lauro Sodré, ou o de Júlio de Castilhos, a convenção do Partido Republicano Federal, do qual falaremos logo a seguir, escolheu por unanimidade o nome de Prudente de Moraes. E este foi eleito Presidente da República pelo sufrágio universal, tendo, todavia, Lauro Sodré recebido certo número de votos (ver Sylvio Peixoto, p. 267 e June Hahner, p. 143). 


\section{1) A desunião política dentro das Forças Armadas, inclusive dentro do} próprio Exército, o que fazia com que Floriano, embora extremamente popular entre certos setores desta corporação, não tivesse condições de comandar uma força armada suficientemente forte para impedir a posse de Prudente ${ }^{172}$. O fato de que a maior parte das Forças Armadas tenha ficado ao lado do governo durante as revoltas não quer dizer que ela se dispusesse a violar a legalidade para manter Floriano no poder. Por outro lado, o Marechal, enquanto liderança cesarista, se colocava acima das próprias Forças Armadas e, embora tivesse sua principal base de apoio numa parte do Exército, ele não podia representar a classe militar como um todo. Finalmente, a própria recusa de florianistas fervorosos, como Moreira César ${ }^{173}$, em tomar parte num movimento golpista teria levado por água abaixo todas as aspirações continuístas de Floriano ${ }^{174}$.

2) A falta de uma base sólida de apoio dentro da elite civil. Através da criação do Partido Republicano Federal (PRF) em 30 de julho de 1893, sob a liderança do paulista Francisco Glicério ${ }^{175}$, a elite política brasileira estava

\footnotetext{
172 June Hahner, pp. 144-145. Aliás, como bem demonstra José Murilo de Carvalho (As Forças Armadas na Primeira República: o Poder Desestabilizador, ver pp. 215-226), as intervenções militares durante toda a República Velha viriam a carecer de coesão, tanto dentro do Exército quanto dentro da Marinha, no primeiro prevalecendo revoltas envolvendo a jovem oficialidade e na segunda havendo o dualismo oficiais $\mathbf{X}$ praças, além da rivalidade com o Exército. Podemos, portanto, supor que dificilmente na Primeira República haveria condições de surgir um líder político-militar que viesse a representar as Forças Armadas como um todo, ao contrário do que viria a acontecer na década de 1930, e sobretudo depois da Intentona de 1935, quando um movimento unificador passaria a procurar a coesão política entre os militares (ver Edmundo Campos Coelho, pp. 117-122).

${ }^{173}$ O Coronel Moreira César chefiara, durante a Revolta da Armada, as forças legais que tomaram, em 17 de dezembro de 1893, a llha do Governador das mãos dos rebeldes (Hélio Leôncio Martins, pp. 266-267). Posteriormente, em abril de 1894, seria nomeado, por Floriano, governador do já reocupado Estado de Santa Catarina, onde seria responsável pelo fuzilamento de dezenas de rebeldes, entre eles Frederico de Lorena e o Barão de Batovi (para maiores detalhes ver Carlos Humberto Corrêa, pp. 144-146).

174 José Maria Bello, p. 131. Como observa Fernando Henrique Cardoso (p. 45), a aliança entre os históricos de São Paulo e os jacobinos militares acabou por sedimentar, de fato, pelo menos em parte da oficialidade, algo mais que o puro ressentimento anti-oligárquico da corporação: um contraditório respeito às instituições e à Lei. Moreira César, arbitrário e mesmo temerário, não aceitará infringir a Constituição para derrubar Prudente, e assim muitos outros, entre os quais o Marechal Artur Oscar de Andrade Guimarães e incontáveis "florianistas" mais.

175 Francisco Glicério, uma das principais lideranças do PRP, homem empreendedor e hábil organizador de alianças políticas, gozava da estima pessoal de Floriano e, na indiferença deste, organizara o PRF, agremiação heterogênea, onde a custo se amalgamavam elementos vindos de todas as origens: republicanos históricos, ex-monarquistas, liberais moderados, conservadores do velho estilo, federalistas, centralizadores, florianistas exaltados ou "legalistas", jacobinos intransigentes, positivistas, presidencialistas irredutíveis, católicos atuantes, livre-pensadores,
} 
arregimentada em torno das candidaturas de Prudente de Moraes para Presidente e do baiano Manuel Vitorino Pereira para Vice ${ }^{176}$ : embora muitas lideranças regionais devessem sua posição de comando às deposições estaduais orquestradas pelo Governo Floriano, elas também desejavam a estabilidade política necessária para consolidar seu poder; isto seria difícil com um governo militar nacionalista, tendente, por sua própria natureza, à centralização e, conseqüentemente, a uma intervenção constante na política dos estados. Por outro lado, o Florianismo também não podia se apoiar, como contrapeso, na embrionária burguesia industrial, cujas atividades nasceram no seio da economia cafeeira e cuja sorte estava presa a ela: segundo Décio Saes ${ }^{177}$, a economia cafeeira gerou mercados consumidores para as indústrias nacionais: ao substituir o trabalho escravo pelo trabalho assalariado, criou extensos mercados rurais; ao determinar a necessidade de criação de um complexo de serviços, criou o consumidor urbano. (...) tais mercados só ofereciam oportunidades crescentes ao setor industrial quando a economia cafeeira se encontrava em expansão ${ }^{178}$. Esta burguesia, de pouca envergadura e ligada à produção de bens de consumo leves que complementavam as importações, condenava $o$ nacionalismo e protecionismo ${ }^{179}$, e portanto só poderia desejar o fim de um governo militar nacionalista, para a subida do PRP. $O$ industrialismo de Floriano a nosso ver não teria base na burguesia industrial brasileira, e sim nas aspirações do progressismo militar, cuja preocupação com a indústria estava ligada à elaboração de um melhor sistema de defesa para o país; esta concepção se desenvolveria melhor durante o Estado Novo, com Góes Monteiro e outros

parlamentaristas e até simpatizantes com a revolta de Custódio de Melo... (José Maria Bello, p. 130). Esta catedral aberta a todos os credos (José Maria Bello, p. 130) carecia, logicamente, de maior definição política e ideológica.

${ }^{176}$ Ver José Sebastião Witter (capítulo I), onde estão expostos os objetivos iniciais dos fundadores do PRF.

${ }^{177}$ Classe Média e Política na Primeira República Brasileira, p. 77.

${ }_{178}$ Dissemos no capítulo II que o desenvolvimento da economia cafeeira também dera origem a um pequeno setor industrial dedicado a artigos como tecidos, vidraria, calçados, cimento, papel e assim por diante.

${ }^{179}$ Ver Décio Saes, Classe Média e Política na Primeira República Brasileira, pp. 78-80. 
militares defensores da criação de indústrias de base e de uma economia de guerra para o Brasil ${ }^{180}$.

3) $O$ poder militar das forças paulistas, que já na época da deflagração da Revolta da Armada contavam com aproximadamente 3000 homens organizados militarmente e bem armados com metralhadoras e equipamentos modernos $^{181}$, era mais um empecilho para uma facção política do Exército procurando se impor sozinha sobre a poderosa elite cafeeira de São Paulo ${ }^{182}$.

4) O precário estado de saúde de Floriano, que o impedia de empreender um grande movimento golpista ${ }^{183}$.

Podemos dizer que o Florianismo tinha apenas, como base concreta de apoio, certos setores do Exército e das camadas médias cariocas, ligados ao jacobinismo. Os republicanos do Rio Grande do Sul, que por afinidade ideológica poderiam ter dado apoio político e material a uma tentativa continuísta do Marechal, estavam por demais ocupados em combater uma revolta que, embora bastante enfraquecida, ainda não terminara, e portanto não podiam sequer sonhar em se envolver na disputa pelo poder federal. Floriano, portanto, terá de ceder diante do fato consumado, isto é a subida do PRP ao poder. Por demais mal humorado $^{184}$, o Marechal se ausenta da cerimônia de transmissão do cargo em 15 de novembro de 1894 no Palácio Itamarati ${ }^{185}$. Assim descreve Hélio Silva (pp. 240-241), baseado em depoimento de Rodrigo Otávio, Secretário da Presidência de Prudente, o ambiente de desolação da cerimônia de posse do novo presidente: O Itamarati recebeu Prudente de portas abertas e salões vazios. Não apresentava o aspecto de uma casa de governo. Não havia uma mesa de trabalho, uma estante de livros, a menor demonstração de vida burocrática. (...) Seguido de

\footnotetext{
${ }^{180}$ Sobre o industrialismo dos militares do Estado Novo, ver Edmundo Campos Coelho, pp. 117119.

${ }^{181}$ June Hahner, p. 133.

182 Bernardino de Campos, Governador de São Paulo, concentrava, em seu estado, todos os batalhões patrióticos paulistas que haviam lutado nas guerras civis, ficando eles aquartelados e esperando a posse de Prudente de Moraes (Edgard Carone, A República Velha (Evolução Política), p. 151).

${ }^{183}$ June Hahner, p. 145.

184 José Maria dos Santos, Bernardino de Campos e o Partido Republicano Paulista, p. 257.

${ }^{185}$ José Maria Bello, p. 132.
} 
poucas pessoas, esguio e solene, um doloroso sorriso em meio àquele cenário, Prudente atravessa as dependências descuidadas. Na grande sala dos fundos, dando para o parque, jazia sobre o assoalho de custoso mosaico de madeira, um caixão aberto, contendo jornais, papéis rasgados, garrafas vazias de cerveja e a palha que as envolvera. Os estofos de alguns móveis foram rasgados a pontaços de baionetas. Era inacreditável!.

\section{E) Epílogo: o Florianismo na oposição.}

\section{1) Prudente de Moraes e a desflorianização.}

Com a ascensão de Prudente de Moraes à Presidência da República, o PRP se apodera de fato do aparelho de Estado republicano. O paulista Rodrigues Alves retorna à pasta da Fazenda ${ }^{186}$ e promove o retorno à sua política econômica ortodoxa de controle das emissões, que passam a ser feitas novamente pelo Tesouro Nacional ${ }^{187}$. Além disso, o Governo Prudente vai realizar uma política que chamaremos aqui de desflorianização, e que vai consistir essencialmente em três pontos: a desmilitarização do país, a pacificação do Rio Grande do Sul e a mudança na política externa.

A desmilitarização do país vai se dar através das seguintes medidas: 1) a redução dos efetivos do Exército ${ }^{188}$; 2) o sucateamento das Forças Armadas, sendo que, por exemplo, o Governo Prudente cancelará, em nome do equilíbrio do Tesouro, a compra de navios de guerra europeus feitas por Floriano no final de

\footnotetext{
${ }^{186}$ Edgard Carone, A República Velha (Evolução Política), p. 153.

187 Renato M. Perissinotto, p. 61. Como pequena concessão feita aos florianistas, temos a nomeação, para a pasta da Guerra, do General Bernardo Vasques, oficial que, como vimos, comandara $\circ$ 6을 Distrito Militar e era abertamente favorável aos castilhistas. O ministério de Prudente é completado pela presença do Almirante Eliziário Barbosa na pasta da Marinha, de Carlos de Carvalho na das Relações Exteriores, Gonçalves Ferreira nas pastas do Interior e da Justiça e Antônio Olyntho no Ministério da Indústria, Viação e Obras Públicas (para todos esses nomes, ver Edgard Carone, A República Velha (Evolução Política), pp. 152-153). Não será nossa intenção fazer uma apresentação de cada nome desse ministério na medida em que a maioria deles não terá peso no contexto do confronto político entre o governo e a oposição florianista.

${ }^{188}$ Segundo June Hahner (p. 148), o efetivo do Exército em 1896 era de 16500 homens, enquanto que em 1893 ele era de 18052.
} 
seu mandato ${ }^{189}$; 3) a criação de um Estado-Maior Geral visando à formação de um exército profissional pequeno e bem organizado ${ }^{190}$, vale dizer um exército disciplinado e subordinado ao poder civil; 4) a exclusão de militares de vários cargos políticos ${ }^{191}$. Por outro lado, os paulistas manterão, ampliarão e modernizarão sua força armada, que a partir de 1901 passará a se chamar Força Pública, uma força treinada e organizada militarmente, pronta para intervir quando a autonomia e os interesses do Estado de São Paulo estiverem ameaçados ${ }^{192}$.

A pacificação do Rio Grande do Sul vai ser resultado de um processo tortuoso. Os rebeldes federalistas, que voltavam a invadir o estado já em 27 de setembro de $1894^{193}$, embora praticamente derrotados ainda não estavam dispostos a entregar as armas, mesmo depois da ascensão de Prudente, que para eles inclusive não significava uma melhora ${ }^{194}$ : o novo presidente, além de antigo aliado do Marechal, louvara, em seu manifesto de posse, a vitória governamental frente à revolta "monárquica" de 6 de setembro de $1893^{195}$. Fora isso, a Revolução Federalista ganhava um novo alento com a liderança militar de Saldanha da Gama, que, aclamado como tal por Silveira Martins e outras lideranças federalistas em maio de $1894^{196}$, organizava, de Montevidéu ${ }^{197}$, um grande invasão do Rio Grande por um exército de 4800 homens, invasão que se dará em janeiro de $1895^{198}$ e que vai iniciar um ciclo de combates com vitórias tanto do

\footnotetext{
189 June Hahner, p. 149.

190 June Hahner, p. 149. O Estado-Maior do Exército, criado em 1896, substituía a Repartição do Ajudante General, existente desde 1856 (J. B. Magalhães, A Evolução Militar do Brasil, p. 315).

191 June Hahner, p. 151.

192 June Hahner, pp. 133-134.

193 Sérgio da Costa Franco, A Guerra Civil de 1893, p. 85.

${ }^{194}$ Edgard Carone, A República Velha (Evolução Política), p. 157.

${ }^{195}$ Edgard Carone, A Primeira República (Texto e Contexto), p. 31.

${ }^{196}$ Edgard Carone, A República Velha (Evolução Política), p. 155.

${ }^{197}$ Com a capitulação dos revoltosos da Armada no Rio de Janeiro, tendo o Governo Floriano recusado as condições de rendição oferecidas por Saldanha da Gama (garantia de vida para os inferiores e retirada dos oficiais revoltosos para o estrangeiro, restituição dos prisioneiros legalistas e entrega das fortalezas, navios de guerra e mais material que estava em poder da revolta), os rebeldes se refugiavam, em número de 525, nas corvetas portuguesas Mindelo e Afonso de Albuquerque, estacionadas na Capital Federal e chefiadas pelo Comandante Augusto de Castilho, o que provocaria grave crise diplomática entre os governos de Brasil e Portugal e levaria ao rompimento das relações diplomáticas entre os dois países (Sérgio Corrêa da Costa, p. 70). As corvetas tendo seguido em direção ao Sul por razões de ordem técnica, os "hóspedes" se evadiram para o Uruguai (ver Hélio Leôncio Martins, pp. 326-340).

${ }^{198}$ Edgar Carone, A República Velha (Evolução Política), pp. 156-157.
} 
lado dos rebeldes quanto das forças legalistas ${ }^{199}$. De qualquer forma, o Governo Prudente vai fazer de tudo para obter a pacificação através da rendição dos revoltosos em troca da anistia ${ }^{200}$. Embora sofrendo a oposição de Bernardo Vasques e de Francisco de Moura, este último exercendo agora o Comando do 6ํㅡㅇ Distrito Militar, de Francisco Glicério e de outros membros do Congresso ligados ao PRF, além de, logicamente, dos próprios castilhistas, que queriam a rendição incondicional dos rebeldes, Prudente continua resoluto em sua meta: substitui Francisco de Moura pelo General Inocêncio Galvão de Queiroz, que inicia negociações com os irmãos Silva Tavares. A morte de Saldanha da Gama junto com duzentos rebeldes no Combate de Campo do Osório em 24 de junho ${ }^{201}$ e o próprio desgaste dos federalistas depois de mais de dois anos de luta levarão à rendição destes, concluindo-se a paz, em troca da anistia, em 23 de agosto de $1895^{202}$, pondo-se fim a um conflito que provocou a morte de 10000 a 12000 pessoas $^{203}$.

A mudança na política externa, por sua vez, visava abandonar o caráter agressivo e anti-europeu vigente no período florianista. O primeiro movimento neste sentido será o reatamento, ocorrido em 16 de março de 1895 com a mediação da Inglaterra, das relações diplomáticas com Portugal, rompidas no ano anterior por Floriano em decorrência do asilo concedido a revoltosos da Armada em corvetas portuguesas estacionadas no Rio de Janeiro ${ }^{204}$.

\section{Esta política de desflorianização favorecia logicamente a elite cafeeira} paulista, que, por estar voltada para o modelo agro-exportador, necessitava de um Brasil politicamente estável e externamente pacífico, sobretudo com as nações européias, de onde vinham empréstimos, capital e colonos para a lavoura. Com a pacificação do Rio Grande do Sul e a desmilitarização, que buscava reduzir a participação dos militares na política, o Governo Prudente procurava a

\footnotetext{
${ }^{199}$ Ver Sérgio da Costa Franco, A Guerra Civil de 1893, pp. 86-88.

${ }^{200}$ Silveira Peixoto, p. 137.

${ }^{201}$ Sérgio da Costa Franco, A Guerra Civil de 1893, pp. 88-89.

${ }^{202} \mathrm{~A}$ anistia aos rebeldes será aprovada pelo Congresso em 21 de outubro do mesmo ano (Edgard Carone, A República Velha (Evolução Política), p. 161).

${ }^{203}$ Luiz Roberto Targa, p. 225. Para maiores detalhes sobre o processo de pacificação do Rio Grande do Sul no Governo Prudente, ver Silveira Peixoto, capítulos 10, 12 e 13.

${ }^{204}$ Silveira Peixoto, p. 142.
} 
estabilidade interna. E a mudança de orientação na política externa visava fazer do Brasil um país "simpático" à Europa. O governo, portanto, evitará a qualquer custo entrar em atrito com países europeus, mesmo quando provocado: nos casos do conflito armado entre brasileiros e tropas francesas no Amapá e da ocupação da ilha de Trindade pelos ingleses, ocorridos respectivamente em maio e julho de $1895^{205}$, Prudente buscará apenas a solução diplomática, sob o protesto dos florianistas e dos nacionalistas em geral, defensores de uma resposta enérgica, leia-se militar, às agressões ${ }^{206}$; no caso do incidente dos Protocolos Italianos (1895-1896), quando o governo de Roma pede ao Brasil compensações por danos causados a seus súditos durante a Revolução Federalista e outros movimentos armados, Prudente cede às exigências, mesmo que sendo acusado de fraqueza diante da arrogância estrangeira ${ }^{207}$. Trata-se de um pacifismo pragmático, segundo o qual a honra nacional vem depois das vantagens comerciais para a elite dominante do país.

\section{2) O fracasso da reação florianista.}

Embora os florianistas estivessem ativos e ferozes na oposição desde 0 início do mandato de Prudente ${ }^{208}$, e tivessem aliados de prestígio como Quintino Bocaiúva, Pinheiro Machado, César Zama e o paulista dissidente Francisco Glicério $^{209}$, além do próprio Vice-Presidente Manuel Vitorino, eles não lograrão criar um ambiente favorável ao desalojamento do PRP.

\footnotetext{
${ }^{205}$ Silveira Peixoto, pp. 147 e 164.

${ }^{206}$ Suely Robles Reis de Queiroz, pp. 36-38.

${ }^{207}$ Suely Robles Reis de Queiroz, pp. 38-42.

${ }^{208}$ Além das investidas virulentas da imprensa jacobina, da ação parlamentar da ala florianista do PRF e de meetings populares com discursos de Martins Júnior, Azevedo Cruz e Raul Pompéia entre outros (ver Suely Robles Reis de Queiroz, pp. 31-51), haverá, durante o Governo Prudente, duas revoltas, de cunho florianista, de alunos da Escola Militar, revoltas ocorridas respectivamente em 13 de março de 1895 e 26 de maio de 1897, no Rio de Janeiro, e rapidamente sufocadas pelo governo (Edgard Carone, A República Velha (Evolução Política), pp. 162 e 172-173).

${ }^{209}$ Glicério, uma das principais figuras do republicanismo paulista, sentira-se frustrado em sua ambição de se tornar, à frente do PRF, uma espécie de condestável da República (assim como tentara inutilmente Custódio de Melo no Governo Floriano). Colocando-se como líder do governo no Congresso e procurando afirmar a soberania deste diante do Poder Executivo, entraria em choque com Prudente, que por sua vez procurava afirmar a autoridade presidencial. Glicério, conseqüentemente, passaria para a oposição, apoiando-se na ala florianista do PRF (ver José
} 
Primeiramente, o Florianismo sofrerá um duro golpe com a morte de seu ícone: no dia 29 de junho de 1895, o Marechal Floriano Peixoto, com a saúde bastante abalada desde os tempos do Paraguai, falecia prematuramente, aos 56 anos de idade, na fazenda de um amigo na Estação de Divisa, Estado do Rio de Janeiro $^{210}$. Mas, de qualquer forma, não será esta a causa determinante do declínio e da morte do Florianismo: como dissemos, este, ao contrário do Deodorismo, que morria com Deodoro devido à própria inexpressividade política de seu líder ${ }^{211}$, continuaria vivo e feroz após a morte de Floriano. O Marechal de Ferro, pouco antes de morrer, escrevia um pequeno testamento político louvando a luta daqueles que permaneceram ao lado de seu governo durante as revoltas e exortando seus seguidores a velar pela salvaguarda da República, ainda ameaçada pelo fermento da restauração ${ }^{212}$. Esta mensagem de cunho belicoso seria o que podemos chamar de "atestado de sobrevivência" do Florianismo, já que seus adeptos estavam autorizados a seguir na luta. Como observa Lincoln de Abreu Penna ${ }^{213}$, a morte de Floriano não o fez desaparecer da cena política da cidade e do País. Ao contrário, as evocações ao "Marechal Vermelho", como preferiam designá-lo os mais ardentes adeptos de um jacobinismo belicoso e de conteúdo mais ideológico, outro dos epítetos que consagraram-no ao longo de sua história, infernizavam o governo de Prudente. O cortejo fúnebre que levava o corpo de Floriano ao Cemitério de São João Batista, no Rio de Janeiro, era assistido por cerca de 30000 pessoas $^{214}$, e daí para a frente, o aniversário da morte de Floriano seria uma das oportunidades para o jacobinismo expressar a sua oposição ao presidente da República, transformando o marechal em herói

\footnotetext{
Maria Bello, pp 138-139 e 151). No entanto, como observa José Sebastião Witter (p. 20), Glicério não era um ideólogo, mas uma natureza despida de quaisquer veleidades intelectuais, sempre disposto em seu pragmatismo a todas as combinações, para superar antagonismos aparentemente inconciliáveis, desde que não o afastassem da meta republicana. Portanto, sua nova postura "florianista" careceria, a nosso ver, de maior conteúdo ideológico.

${ }^{210}$ Salm de Miranda, pp. 328-329.

211 Deodoro, politicamente falando, não passava de um instrumento de grupos neomonárquicos desejosos de retornar ao poder. Fora isso, não encontramos no Deodorismo nenhum projeto claro de desenvolvimento nacional, o que transformaria, a nosso ver, seu líder numa figura inexpressiva.

${ }^{212}$ Ver Salm de Miranda, pp. 329-330.

${ }^{213}$ Por que somos Florianistas?, p. 86.

${ }^{214}$ Lincoln de Abreu Penna, Por que somos Florianistas?, p. 85.
} 
decidido e Prudente na sua antítese ${ }^{215}$ : em suma, Floriano, militar e nacionalista, representava a força; Prudente, civil e liberal, a fraqueza. E o fantasma de Floriano atormentaria o Governo Prudente por mais dois anos.

Se a morte do Marechal de Ferro privava o Florianismo de sua grande liderança e de seu grande chamativo popular, o fim desta corrente política vai se dever sobretudo a outros fatores, como os já citados falta de base de apoio sólida dentro da elite civil $^{216}$, desunião política dentro das Forças Armadas, poderio militar das forças paulistas, e, um novo, que será o desempenho decepcionante do Exército na Guerra de Canudos (1896-1897). Este fator, de ordem simbólica, irá ferir de morte o Florianismo, devido ao prestígio abalado dos oficiais florianistas do Exército envolvidos na campanha.

Não entraremos em detalhes sobre o episódio de Canudos, assunto estudado por vasta bibliografia de qualidade. No entanto, abordaremos o contexto político que girou em torno do conflito, já que ele terá papel de peso no desaparecimento do Florianismo.

Com o afastamento temporário, por razões de saúde, de Prudente de Moraes da Presidência da República em novembro de 1896, Manuel Vitorino, com nítidas intenções de se manter no poder, nomeia um ministério próprio, colocando um oficial florianista, o General Francisco de Paula Argolo, na pasta da Guerra. Como observa Marco Antonio Villa ${ }^{217}$, para Manuel Vitorino a aproximação com os florianistas significava a possibilidade de isolar o Partido Republicano Paulista e seus aliados regionais, obrigando o presidente a renunciar a seu favor. Entretanto, longe de representar uma inserção do progressismo militar dentro da elite civil, esta aliança é apenas tática, já que o paulista Bernardino de Campos passa a

\footnotetext{
${ }^{215}$ Suely Robles Reis de Queiroz, p. 35.

${ }^{216}$ A própria aliança do Florianismo com lideranças políticas como Francisco Glicério e Manuel Vitorino, além de carecer de verdadeira afinidade ideológica, também não representava um pacto com grupos sociais importantes: tanto Glicério quanto Manuel Vitorino estavam na oposição em seus estados e em nítida situação de inferioridade, a Bahia sendo governada por Luís Viana, adversário de Manuel Vitorino e aliado de Prudente de Moraes (Luís Henrique Dias Tavares, p. 39, e Edgard Carone, A República Velha (Evolução Política), p. 178), e São Paulo sendo governado desde 1896 por Campos Sales, que, como típico representante do PRP, se mantinha fiel ao Presidente da República (Silveira Peixoto, p. 222).

${ }^{217}$ Canudos: o campo em chamas, p. 45.
} 
ocupar o Ministério da Fazenda ${ }^{218}$ e o liberal ortodoxo Joaquim Murtinho o da Indústria, Viação e Obras Públicas ${ }^{219}$ : isto é, a política de desenvolvimento não é alterada, permanecendo voltada para o modelo agro-exportador. Manuel Vitorino, que durante o Governo Floriano fizera parte da base de apoio do Marechal no Senado Federal, por ver o autoritarismo florianista como "menos perigoso" do que o autoritarismo dos revoltosos ${ }^{220}$, não poderia, de forma alguma, ser considerado um representante do Florianismo e do progressismo militar dentro do mundo civil; suas posições favoráveis à anistia aos rebeldes federalistas ${ }^{221}$, indo contra a posição mais dura dos florianistas e dos castilhistas, nos faz supor que de fato 0 político baiano pouco divergia ideologicamente dos paulistas. Como observa Luiz Henrique Dias Tavares (p. 45), a própria visão de Manuel Vitorino era limitada; atinha-se ao administrativo. Desejava "cuidar unicamente da administração"; liquidar "uma série de erros" nas finanças; estabelecer "severas e largas economias". Um elenco moralizante de classe média...

De qualquer forma, o aparecimento, em pleno sertão da Bahia, de uma comunidade rebelde de orientação monárquica e católica, será a grande oportunidade para Manuel Vitorino e seus aliados florianistas explorarem um grande sucesso político e militar. Canudos (ou Belo Monte), comunidade popular originária de uma revolta anti-tributária ${ }^{222}$ e adotando como arma ideológica um catolicismo conservador (mesmo que do ponto de vista institucional independente da Igreja) ${ }^{223}$ e uma nostalgia do regime deposto, culpando a República pelos

\footnotetext{
${ }^{218}$ Bernardino de Campos propunha-se, com o consentimento do afastado Prudente, a entrar para a pasta da Fazenda para manter viva a chama do PRP dentro do Governo Manuel Vitorino, e dificultar uma tentativa golpista por parte do Vice-Presidente em exercício (José Maria dos Santos, Bernardino de Campos e o Partido Republicano Paulista, p. 258).

${ }^{219}$ Para a mudança ministerial promovida por Manuel Vitorino, ver Edgard Carone, A República Velha (Evolução Política), pp. 166-167.

${ }^{220}$ Luiz Henrique Dias Tavares, p. 38.

${ }^{221}$ Ver Edgard Carone, A República Velha (Evolução Política), pp. 160 e 166-167.

${ }^{222} \mathrm{O}$ acontecimento que levou Antônio Conselheiro e seus seguidores a se rebelarem abertamente contra o Estado e se instalarem definitivamente no arraial de Canudos foi a revolta contra os impostos municipais ocorrida em Bom Conselho (Bahia) no ano de 1893 (ver Duglas Teixeira Monteiro, p. 60).

${ }^{223}$ Ao estudar as prédicas de Antônio Conselheiro, Duglas Teixeira Monteiro faz, nas pp. 65-68, uma ótima síntese do pensamento político e teológico do líder espiritual de Canudos, onde encontramos a defesa de uma ordem divina que admite, na esfera econômico-social, desigualdades, de um rígido puritanismo no que diz respeito aos costumes, penas duras para os infratores da Lei e um discurso contra a República (e seu laicismo), os judeus (negadores de
} 
impostos, pelo censo, pelo casamento civil, etc., em suma este movimento ao mesmo tempo plebeu e reacionário, caía como uma luva para os grupos políticos desejosos de ressuscitar o clima de jacobinismo reinante nos tempos de Floriano e enfraquecer os republicanismo liberal do PRP e seus aliados. Tendo fracassado as duas primeiras expedições militares, enviadas pelo Governo do Estado da Bahia, contra a "nossa Vendéia"224, o Governo Manuel Vitorino decretava intervenção federal e nomeava, em fevereiro de 1897, o Coronel do Exército Antônio Moreira César, florianista notório, para o comando de uma expedição composta de 1300 homens e com artilharia ${ }^{225}$, expedição que estava destinada a ser a glória da aliança Manuel Vitorino/Florianismo e uma grande arma na luta contra Prudente e seus aliados dentro e fora do PRP: mais do que uma luta contra a rebelião monarquista, tratava-se de uma verdadeira cisão dentro do aparelho de Estado.

Mas o que estava destinado a ser um sucesso político, transformou-se num grande fracasso. Embora o Exército e suas forças auxiliares (polícias estaduais, batalhões patrióticos, etc.) tenham saído incontestavelmente vitoriosos do conflito contra os jagunços de Antônio Conselheiro, foi preciso quatro expedições, mais a intervenção direta do Ministro da Guerra, Marechal Machado Bittencourt ${ }^{226}$, para derrotar o movimento. Isto se explica por diversos fatores, como as dificuldades proporcionadas pelo terreno do sertão da Bahia, um serviço de logística precário, a tática de guerrilha e o fervor religioso dos conselheiristas, além da falta de infraestrutura dentro do território brasileiro em geral. Portanto, mesmo se o

Cristo), os protestantes e os maçons. A imagem de Antônio Conselheiro como o propagador de um "cristianismo socialista" portanto não poderia ser mais falsa.

${ }^{224}$ Para maiores detalhes sobres as expedições comandadas respectivamente pelo Tenente do Exército Pires Ferreira e pelo Major, também do Exército, Febrônio de Brito, ver Euclides da Cunha, Os Sertões, pp. 189-208.

${ }^{225}$ Euclides da Cunha, Os Sertões, p. 255.

${ }^{226}$ Prudente de Moraes, percebendo a manobra continuísta de seu vice, voltava às pressas ao seu posto em março de 1897. Pouco depois, o apolítico Bittencourt substituía o florianista Argolo na pasta da Guerra, devido à resistência deste último oficial à política de redução dos efetivos do Exército (Silveira Peixoto, p. 214). A contribuição de Bittencourt para a vitória final das forças governamentais foi a de reorganizar o serviço de logística, criando um corpo regular de comboios que ligava as tropas combatentes comandadas por Artur Oscar à base de operações em Monte Santo (ver Euclides da Cunha, Os Sertões, pp. 418-423). Acreditamos que o fato de um oficial legalista e apolítico ter socorrido um oficial florianista (Artur Oscar) durante a guerra, só ajudou a manchar o prestígio militar do Florianismo. 
Exército não pode ser considerado culpado pela demora da campanha (quase um ano), a culpa recaiu nele: os milhares de baixas entre as forças do governo, a morte em combate de Moreira César, comandante da terceira expedição além de florianista e republicano fervoroso, e as enormes dificuldades enfrentadas pelo florianista vermelho Artur Oscar ${ }^{227}$, comandante da quarta expedição, foram um golpe duro no Florianismo e no prestígio político dos militares, fortalecendo a posição do PRP e de seus aliados: morto Moreira César, os florianistas viam em Artur Oscar o soldado prestigioso que acrescido de glórias pelos rápidos louros de Canudos, devia de volta expulsar do governo os traidores da república. O triunfo sobre o famoso reduto jagunço, prolongando-se imediatamente na deposição do governador Luis Viana, da Bahia, deveria completar-se, no Rio de Janeiro, pela ocupação manu militari do palácio do Catete $^{228}$. Mas, como observa Silveira Peixoto (p. 232), os erros e desastres iniciais, os revezes que se sucederam numa seqüência aterrorizadora, a estagnação em Queimadas e Monte Santo, a imobilidade na Favela e, depois, nos arredores de Canudos, tudo isso já se encarregou de vibrar sérios golpes no prestígio do general Artur Oscar. 0 comandante-chefe da expedição não é mais o homem que tão açodadamente esperavam os conspiradores. Em suma, os florianistas, que sonhavam com o General Bonaparte que voltaria da campanha do Egito para depor a República do Diretório, deviam se conformar com uma "vitória mutilada" sobre os conselheiristas, vitória benéfica apenas ao Governo Prudente, que tendo conseguido reprimir a rebeldia monarquista do sertão, não precisava dividir as glórias com os militares, cujo prestígio estava abalado pela demora da campanha ${ }^{229}$.

Depois de Canudos o Florianismo estava praticamente acabado. atentado frustrado de 5 de novembro de 1897 contra Prudente de Moraes, atentado onde morre o Ministro da Guerra e no qual estavam envolvidos não

${ }^{227}$ O General Artur Oscar de Andrade Guimarães se destacara como oficial legalista na luta contra os federalistas durante a guerra civil no Sul (José Maria Bello, p. 152) e comandava o $2^{\circ}$ Distrito Militar, sediado em Recife, quando nomeado para o Comando da $4^{\mathrm{a}}$ expedição contra Canudos (Marco Antonio Villa, Canudos: o povo da terra, p. 176).

${ }_{228}$ José Maria dos Santos, A Política Geral do Brasil, p. 281.

${ }^{229}$ Para maiores detalhes sobre o sangrento episódio de Canudos, ver o clássico Os Sertões, de Euclides da Cunha, e os dois livros de Marco Antonio Villa que constam na bibliografia. 
somente os florianistas como também nomes como Francisco Glicério, Pinheiro Machado, Quintino Bocaiúva, Manuel Vitorino, Barbosa Lima, Irineu Machado, Alcindo Guanabara e Ramiro Barcellos, entre outros ${ }^{230}$, é ao mesmo tempo o golpe de misericórdia no Florianismo (e em seus aliados ocasionais) e o acontecimento simbólico que marca a consolidação da hegemonia do PRP a nível nacional: com a morte de Bittencourt, que passa a ser visto como uma espécie de "mártir da legalidade" assassinado pelo punhal do soldado florianista Marcelino Bispo $^{231}$, o governo ganha o apoio da população, que, se antes não the era hostil pelos menos lhe era indiferente, e a oposição florianista, desmoralizada, se cala 232 .

Podemos dizer que o atentado de 5 de novembro de 1897 encerra um longo período revolucionário que teve início com a abolição da escravidão, isto é a eliminação da base de sustentação do Estado imperial, e que terminou com a consolidação da república civil sob a hegemonia do PRP, representante da elite cafeeira paulista, que estava destinada, por sua prosperidade e importância na renda nacional, a se apoderar do aparelho de Estado republicano: o patriótico projeto florianista, muito avançado para seu tempo, não podia se sustentar naquele momento. Como observa pertinentemente Luís Henrique Dias Tavares (p. 38), a ascensão da oligarquia paulista ao comando do país já se esboçara desde a proclamação da República, mas ganhara privilégio no episódio do contra-golpe que depôs o marechal Deodoro e elevou à presidência o vice-presidente, marechal Floriano Peixoto. Explica-se essa gravitação para um novo centro pela circunstância de ser economicamente a oligarquia paulista a mais poderosa das oligarquias estaduais. Era a oligarquia do café, produto primário cuja produção o capitalismo internacional apoiava com suas compras e sua participação no mercado externo.

\footnotetext{
${ }^{230}$ Para maiores detalhes, ver Suely Robles Reis de Queiroz, pp. 61-79, e Silveira Peixoto, capítulos 19 a 21.

${ }_{231}^{23}$ Ver Silveira Peixoto, p. 302.

232 José Maria Bello, pp. 154-155.
} 
Em 15 de novembro de 1898, Prudente entrega o cargo presidencial a seu sucessor legal, Campos Sales ${ }^{233}$, que irá realizar um governo, do ponto de vista econômico, favorável ao grande capital cafeeiro (e em detrimento da lavoura cafeeira $^{234}$ ) e, do ponto de vista político, baseado na aliança do poder federal com as situações estaduais (é a famosa política dos governadores), no intuito de se evitar a exacerbação da luta local e sua repercussão a nível nacional (caso da Revolução Federalista) e de conseguir a tão desejada estabilidade política interna $^{235}$. O PRF, tendo fracassado em sua missão de criar uma estrutura partidária republicana de âmbito nacional, se desintegrava ${ }^{236}$, deixando a República nas mãos do PRP e de seus aliados estaduais: como afirma José Sebastião Witter (p. 132), acreditamos mesmo que a experiência vivida por Campos Salles durante o primeiro decênio republicano fez com que ele não tentasse, como presidente, aglutinar forças em torno de uma agremiação partidária, nem mesmo uma participação nacional em torno do presidencialismo centralizador. Preferiu optar pela fórmula conhecida por "política dos governadores", entendendo, talvez, ser essa a solução para os problemas nacionais, de vez que com ele, Campos Salles, se entendiam os Governadores dos Estados e estes tomavam as suas decisões, fazendo, cada qual à sua maneira, a política regional, com a qual estavam mais familiarizados. Quanto ao Florianismo, ele desaparecia: as medidas repressivas tomadas pelo governo após o atentado, como o estado de sítio para o Distrito Federal e Niterói, o fechamento do Clube Militar e o desterro de diversos florianistas para a ilha de Fernando de

\footnotetext{
${ }^{233}$ Campos Sales derrotara o florianista Lauro Sodré nas eleições de 4 de março de 1898 (Edgard Carone, A República Velha (Evolução Política), p. 189).

${ }^{234}$ A política de saneamento financeiro promovida pelo Governo Campos Sales (1898-1902), política dentro da qual está inserido o funding loan, beneficiou tanto o setor ferroviário, ao baratear os custos das ferrovias e ampliando suas receitas, quanto o setor importador, ao garantir competitividade aos produtos importados. A situação da lavoura, por sua vez, era desesperadora devido à confluência da queda internacional do preço do café e da política governamental de valorização cambial. Como conseqüência desta política, esboçou-se a criação de um Partido da Lavoura, visando defender os interesses desta frente ao grande capital cafeeiro (ver Renato M. Perissinotto, pp. 49 e 62-66). Se até o final do Governo Prudente a elite cafeeira paulista se mantivera unida devido às ameaças políticas ao seu domínio, a partir do Governo Campos Sales seus dois principais ramos, isto é o grande capital cafeeiro e a lavoura cafeeira, entrariam em constante atrito devido às políticas econômicas favoráveis àquele (ver Décio Saes, A Formação do Estado burguês no Brasil, pp. 346-347).

235 Eduardo Kugelmas, pp. 69-70.

236 José Sebastião Witter, pp. 128-130.
} 
Noronha ${ }^{237}$ contribuirão para enterrar o movimento já moribundo; posteriormente, a lamentável participação de remanescentes como Lauro Sodré, Barata Ribeiro e Barbosa Lima (junto com o castilhista Alfredo Varela) na obscurantista Revolta da Vacina (1904), aproveitando-se, ao lado de anarquistas, monarquistas e lideranças operárias, do medo popular frente à heróica campanha de Oswaldo Cruz contra a varíola para desestabilizar o governo do Presidente Rodrigues Alves $^{238}$, era um sinal de que o Florianismo já havia cumprido seu papel histórico e que suas idéias, que vinham do progressismo militar, só poderiam voltar em outro contexto e ser defendidas por outras gerações.

\footnotetext{
${ }^{237}$ Para maiores detalhes sobre a repressão aos envolvidos no atentado, repressão que no entanto poupou figuras de maior relevo como Francisco Glicério, Quintino Bocaiúva e Pinheiro Machado, que ficaram apenas na situação de "suspeitos" (muitos deles inclusive eram apenas coniventes, sem terem participado de fato da conspiração), ver Silveira Peixoto, capítulos 20 e 21.

${ }_{238}$ Para maiores detalhes sobre a Revolta da Vacina e seus participantes, ver José Murilo de Carvalho, Os Bestializados, capítulo IV.
} 


\section{CONCLUSÃO}

Como afirma Wilma Peres Costa (p. 17), a República Oligárquica não nasceu pronta no 15 de novembro, mas foi o resultado de um lento e conflitivo processo de lutas e transações, no qual foram cooptados ou alijados os projetos republicanos rivais. Além do "bloco agrário", capitaneado pela cafeicultura paulista, pelo menos duas outras forças estiveram presentes no movimento republicano: importantes setores das camadas médias e da intelectualidade urbana, que pela primeira vez passaram a fazer parte da cena política, e o exército, elemento decisivo para a derrubada da monarquia. Ora, as motivações antimonárquicas de cada uma dessas forças eram distintas, resultando em expectativas diferentes em relação à construção da nova ordem. Mais do que isso, no caso dos dois componentes mais orgânicos da "frente republicana" - a cafeicultura paulista e as forças armadas - essas motivações eram até mesmo antagônicas.

Abordamos neste trabalho o tema do Florianismo, um dos principais atores do violento e complicado jogo político acima descrito, procurando inseri-lo dentro do contexto político de sua época e demonstrar seu papel determinante na construção da ordem republicana que vigorou até 1930. No Capítulo I, tentamos definir o Florianismo traçando um perfil biográfico do Marechal, apresentando as principais características de seu governo presidencial e de seus seguidores, e chegando a uma identificação do fenômeno em questão como Cesarismo Progressista. No Capítulo II, abordamos o Deodorismo, definindo-o como Cesarismo Reacionário e procurando mostrar como a instabilidade política provocada por seu conservadorismo levou ao advento do Florianismo. Finalmente, no Capítulo III, tratamos das lutas políticas girando em torno do Florianismo entre 1891 e 1897, e procuramos mostrar, através da interpretação dos principais acontecimentos políticos do período, o papel histórico deste fenômeno.

Para respondermos à questão por nós colocada, isto é qual o papel do Florianismo (1891-1897) na implantação da ordem política da República Velha, voltemos às hipóteses de trabalho que apresentamos na Introdução. Ao levantarmos essas hipóteses, partimos do pressuposto de que o Florianismo é um 
fenômeno político-militar nacionalista, autoritário e progressista : o fato de Floriano ser um alto oficial do Exército e representar, por suas posições, as aspirações políticas da oficialidade progressista desta corporação (embora, como liderança cesarista, se colocasse acima dela), além de ter, entre seus seguidores, grande número de militares, nos permite afirmar que o Florianismo é de fato um fenômeno político-militar ; quanto ao seu autoritarismo e ao seu progressismo, demos provas ao longo do Capítulo I, ao expor as principais características do Governo Floriano e as principais posições de seus seguidores. Vejamos agora as hipóteses :

1) O Florianismo, em seu período no poder presidencial, ao receber 0 apoio político e material de São Paulo, terá a função de preparar a ascensão do Partido Republicano Paulista a nível federal, na medida em que seu governo autoritário irá, pela força, desalojar do poder os remanescentes da antiga elite imperial. Vimos que o Deodorismo, com sua política centralista e de aliança com a burguesia bancária do Rio de Janeiro (uma das principais frações da antiga elite monárquica), além de prejudicar as atividades econômicas da elite cafeeira paulista, punha em cheque a liderança política do PRP tanto a nível federal quanto a nível estadual, este partido correndo inclusive o risco de desaparecer da arena política. A ascensão do Florianismo, isto é a saída de Sila para a entrada de César, será a salvação do PRP na medida em que ele entrará em choque com grupos conservadores, oriundos da elite imperial, e cujos interesses eram antagônicos aos dos paulistas, além de travar guerra com facções militares rivais que poderiam posteriormente travar a ascensão paulista. Isto que levará a uma curiosa aliança Florianismo/PRP: se por um lado este bancava a permanência daquele frente às revoltas, o Florianismo arregimentava tropas na luta contra inimigos comuns aos dois (deodoristas, federalistas gaúchos, revoltosos da Armada). O Florianismo, vitorioso no campo de batalha, "sujava suas mãos de sangue" e abria o caminho para a ascensão do PRP.

2) O Florianismo, possuindo um projeto político, econômico e social diferente daquele defendido pelo Partido Republicano Paulista, tendo concluído sua missão histórica, passou, com a ascensão de Prudente de Moraes à Presidência da República, para a oposição; a ação política dos 
florianistas, embora virulenta, se mostrou destituída de apoio sólido após o rompimento com São Paulo, e o movimento desapareceu para triunfo da república civil sob controle paulista e, posteriormente, também mineiro. Vimos que os projetos florianista e "perrepista" eram antagônicos, já que o primeiro era nacionalista, autoritário e industrialista, e o segundo liberal e voltado para o modelo agro-exportador, e que, por outro lado, o Florianismo, carecendo de base mais sólida de apoio, tanto nas Forças Armadas quanto na elite civil, acabou sendo desalojado do poder, passando a maior parte do mandato de Prudente numa oposição, barulhenta porém infrutífera, que teria como duplo golpe de misericórdia o mau desempenho do Exército em Canudos e o atentado frustrado ao Presidente da República.

Como afirma José Maria dos Santos ${ }^{1}$, sem o Marechal Floriano Peixoto o PRP estava morto. Com a vitória política e militar sobre seus oponentes, o Florianismo assegurava, contra a própria vontade, o triunfo da ordem republicana que viria a ser dominada pelo PRP e seus aliados até 1930. Neste caso, Floriano teria sido batizado como Consolidador da República mais por ter derrubado os obstáculos à implantação da ordem política da República Velha do que por ter salvo o sistema republicano de governo de uma tentativa restauradora, que de fato nunca ocorreu. Por outro lado, podemos dizer que a caracterização do Florianismo como Cesarismo Progressista se deve a esse seu papel: no confronto entre a relativamente progressista elite cafeeira paulista e algumas frações da reacionária elite imperial, o Florianismo surgia como terceira força submetendo os dois campos em choque, procurando estabelecer um governo de tipo pessoal, mas ao mesmo tempo favorecendo os paulistas, aliando-se a eles e ajudando-os indiretamente a triunfar. Mas, a elite cafeeira paulista tendo conseguido se estruturar a nível nacional (com a ajuda inclusive do PRF e das elites locais desejosas de se livrar do militarismo nacionalista e centralista), o Cesarismo deixava de ser imprescindível para o equilíbrio político e social da Nação, e não tinha mais como se sustentar no

\footnotetext{
${ }^{1}$ Bernardino de Campos e o Partido Republicano Paulista, p. 251.
} 
poder; o Cesarismo tendo sido resultado de uma crise no seio das elites, passada esta não tinha mais razão de ser.

O Florianismo, uma expressão do progressismo militar nascido nos bancos da Escola Militar e nos campos de batalha do Paraguai, desaparecia, portanto, após o cumprimento de seu papel histórico. Todavia, o espírito do progressismo militar irá se manifestar ao longo da Primeira República (movimento dos Jovens Turcos ${ }^{2}$, rebeliões tenentistas), desembocando na Revolução de 1930 e posteriormente no Estado Novo (1937-1945), em cujo quadro o nacionalismo militar, associado ao nacionalismo varguista, irá promover a industrialização pesada no Brasil.

\footnotetext{
${ }^{2}$ Estamos nos referindo aos jovens oficiais do Exército Brasileiro que, após terem estagiado na Alemanha, iniciaram, na década de 1910, um movimento em prol da modernização da estrutura militar brasileira, sendo chamados de jovens turcos por lembrarem a jovem oficialidade do Exército Turco que visava modernizar a estrutura militar de seu país (ver José Murilo de Carvalho, As Forças Armadas na Primeira República: o Poder Desestabilizador, pp. 198-199).
} 
BIBLIOGRAFIA

ALMEIDA, Fernando H. Mendes de. Constituições do Brasil. $3^{a}$ ed. Revista e atualizada. São Paulo: Edição Saraiva, 1961.

ALONSO, Ângela. Idéias em movimento: a geração de 1870 na crise do BrasilImpério. São Paulo: Paz e Terra, 2002.

BARROSO, Gustavo. História Militar do Brasil. Rio de Janeiro: Biblioteca do Exército, 2000.

BASBAUM, Leôncio. História Sincera da República 1889-1930. São Paulo: Fulgor, 1968, $3^{\mathrm{a}}$ ed.

BELLO, José Maria. História da República 1889-1954. São Paulo: Companhia Editora Nacional, 1976, $7^{\mathrm{a}}$ ed.

BURNS, Edward McNall. História da Civilização Ocidental. Volume II. Porto Alegre: Editora Globo, 1959, $2^{\underline{a}}$ ed.

CAMEU, Francolino, PEIXOTO, Arthur Vieira. Floriano Peixoto. Vida e Governo. Brasília: Editora Universidade de Brasília, 1983.

CARDOSO, Fernando Henrique. Dos Governos Militares a Prudente-Campos Sales in FAUSTO, Boris, História Geral da Civilização Brasileira. Tomo III: 0 Brasil Republicano. $1^{\circ}$ Volume: Estrutura de poder e economia (1889-1930). São Paulo: DIFEL, 1975.

CARNEIRO, Glauco. História das Revoluções Brasileiras. $1^{\circ}$ Volume: Da Revolução da República à Coluna Prestes (1889/1927). Rio de Janeiro: Edições O Cruzeiro, 1965.

CARONE, Edgard. A Primeira República (Texto e Contexto). São Paulo: Difusão Européia do Livro, 1969.

A República Velha (Evolução política). São Paulo: Difusão Européia do Livro, 1977. $3^{\mathrm{a}}$ ed.

CARVALHO, José Murilo de. Os Bestializados: o Rio de Janeiro e a República que não foi. São Paulo: Companhia das Letras, 2002, $3^{\mathrm{a}}$ ed.

As Forças Armadas na Primeira República: o

Poder Desestabilizador in FAUSTO, Boris, História Geral da Civilização 
Brasileira. Tomo III: 0 Brasil Republicano. $2^{\circ}$ Volume: Sociedade e Instituições (1889-1930). Rio de Janeiro: Bertrand Brasil, 1997, $5^{\text {a }}$ ed.

CASALECHI, José Ênio. O Partido Republicano Paulista (1889-1926). São Paulo: Brasiliense, 1987.

CASTRO, Celso. Os Militares e a República. Rio de Janeiro: Zahar, 1995.

CASTRO, Jeanne Berrance de. A Guarda Nacional in HOLANDA, Sérgio Buarque de, História Geral da Civilização Brasileira. Tomo II: O Brasil Monárquico. $4^{\circ}$ Volume: Declínio e Queda do Império. São Paulo: DIFEL, 1974, $2^{\mathrm{a}}$ ed.

COELHO, Edmundo Campos. Em busca de identidade: o Exército e a política na sociedade brasileira. Rio de Janeiro: Record, 2000.

CORRÊA, Carlos Humberto. Militares e civis num governo sem rumo: o Governo Provisório revolucionário de Desterro 1893-1894. Florianópolis: Editora da UFSC: Ed. Lunardelli, 1990).

CORRÊA, Serzedello. Páginas do passado, Floriano Peixoto na intimidade o mesmo na vida pública (Subsídio para a história). Rio de Janeiro: Off. Graphicas do Jornal do Brasil, 1919.

COSTA, Sérgio Corrêa da. A Diplomacia do Marechal. Rio de Janeiro: Tempo Brasileiro, 1979, $2^{a}$ ed.

COSTA, Wilma Peres. A Espada de Dâmocles: o Exército, a Guerra do Paraguai e a crise do Império. São Paulo: HUCITEC/UNICAMP, 1996.

CUNHA, Euclides da. Os Sertões. Rio de Janeiro: Francisco Alves/Publifolha, $2000,39^{\mathrm{a}}$ ed.

Contrastes e Confrontos. São Paulo: Cultrix, 1975.

FERREIRA, Oliveiros S. Vida e Morte do Partido Fardado. São Paulo: Senac, 2000.

FRANCO, Sérgio da Costa. A Guerra Civil de 1893. Porto Alegre: Editora da Universidade/UFRGS, 1993.

Júlio de Castilhos e sua época. Porto Alegre:

Editora da Universidade/UFRGS, 1996, $4^{\mathrm{a}}$ ed. 
GRAMSCI, Antonio. Maquiavel, a Política e o Estado Moderno. Rio de Janeiro: Civilização Brasileira, 1968.

A Questão Meridional. Rio de Janeiro: Paz e Terra, 1987.

GREMAUD, Amaury Patrick, SAES, Flávio Azevedo Marques de, TONETO JÚNIOR, Rudinei. Formação Econômica do Brasil. São Paulo: Atlas, 1997.

HAHNER, June. Relações entre Civis e Militares no Brasil (1889-1898). São Paulo: Pioneira, 1975.

HISTÓRIA NOVA DO BRASIL Vol. IV. Abolição - Advento da República Florianismo. São Paulo: Brasiliense, 1964.

HUNTINGTON, Samuel P. O Soldado e o Estado: Teoria e Política das Relações entre Civis e Militares. Rio de Janeiro: Biblioteca do Exército, 1996.

IZECKSOHN, Vitor. O Cerne da Discórdia: A Guerra do Paraguai e o Núcleo Profissional do Exército. Rio de Janeiro: Biblioteca do Exército, 1997.

JANOTTI, Maria de Lourdes Mônaco. Os Subversivos da República. São Paulo: Brasiliense, 1986.

KUGELMAS, Eduardo. Difícil hegemonia: um estudo sobre São Paulo na Primeira República. Tese de Doutoramento apresentada no Departamento de Ciências Sociais da Universidade de São Paulo, São Paulo, 1986.

LARANJEIRA, Joaquim. Floriano Peixoto. Rio de Janeiro: Andersen Editores, s/d.

LIMA BARRETO. Triste Fim de Policarpo Quaresma. São Paulo: Gráfica Editora Brasileira, 1948, 3ª ed.

MACEDO, Roberto. A Administração de Floriano. 5ำ volume da série Floriano: Memórias e Documentos. Rio de Janeiro: Ministério da Educação, 1939.

MACHADO, Eurico Serzedello. Um Republicano: a vida de Serzedello Corrêa. Companhia Editora Americana, 1972.

MAGALHÃES, J. B. A Consolidação da República. Rio de Janeiro: Laemmert, 1947.

Evolução Militar do Brasil. Rio de Janeiro: Biblioteca do Exército, $1998,2^{\mathrm{a}}$ ed. 
MAGALHÃES JÚNIOR, R. Deodoro, a Espada contra o Império. 2 vols. São Paulo: Companhia Editora Nacional, 1957.

MAIA, J. Gonçalves. Horas de Prisão. Recife: Imprensa Universitária, 1967, 2ª ed.

MARTINS, Hélio Leôncio. A Revolta da Armada. Rio de Janeiro: Biblioteca do Exército, 1997.

MARX, Karl. Les luttes de classe en France / Le 18 Brumaire de Louis Bonaparte. Editions Sociales, 1965.

MATTOS, Ilmar Rohloff de. O Tempo Saquarema: a formação do Estado Imperial. São Paulo: HUCITEC, 2004, 5ª ed.

MELLO, Almirante Custódio José de. O Governo Provisório e a Revolução de 1893. 2 tomos. São Paulo: Companhia Editora Nacional, 1938.

MIRANDA, Salm de. Floriano. Rio de Janeiro: Biblioteca do Exército, 1963.

MIYAMOTO, Shiguenoli. Geopolítica e poder no Brasil. Campinas-SP: Papirus, 1995.

MONTEIRO, Duglas Teixeira. Um confronto entre Juazeiro, Canudos e Contestado. In FAUSTO, Boris. História Geral da Civilização Brasileira. Tomo III: O Brasil Republicano. 2o Volume: Sociedade e Instituições (1889-1930). Rio de Janeiro: Bertrand Brasil, 1997, $5^{\mathrm{a}}$ ed.

MONTEIRO, Tobias. Pesquisas e Depoimentos para a História. Belo Horizonte: Itatiaia/São Paulo: Editora da Universidade de São Paulo, 1982.

MORAES, João Quartim de. A Esquerda Militar no Brasil: Da Conspiração Republicana à Guerrilha dos Tenentes. São Paulo: Siciliano, 1991.

MOTTA, Jeovah. Formação do oficial do Exército (Currículos e regimes na Academia Militar 1810-1944). Rio de Janeiro: Companhia Brasileira de Artes Gráficas, 1976.

NABUCO, Joaquim. A Intervenção Estrangeira Durante a Revolta de 1893. Rio de Janeiro: Freitas Bastos, 1932.

PEIXOTO, Sílvio. No Tempo de Floriano. Rio de Janeiro: A Noite, 1940.

PEIXOTO, Silveira. A Tormenta que Prudente de Moraes Venceu! São Paulo: IMESP, 1990, $2^{\mathrm{a}}$ ed. 
PENNA, Lincoln de Abreu. O Progresso da Ordem: o florianismo e a construção da República. Rio de Janeiro: Sette Letras, 1997.

Por que somos Florianistas? Ensaios sobre

Florianismo e Jacobinismo. Rio de Janeiro: E-papers, 2002.

PERISSINOTTO, Renato M. Classes Dominantes e Hegemonia na República Velha. Campinas: UNICAMP, 1994.

PESAVENTO, Sandra Jatahy. História do Rio Grande do Sul. Porto Alegre: Mercado Aberto, 1990, 5ª ed.

A Revolução Federalista. São Paulo: Brasiliense, 1983.

QUEIROZ, Suely Robles Reis de. Os Radicais da República. Jacobinismo: ideologia e ação 1893-1897. São Paulo: Brasiliense, 1986.

RÉMOND, René. O Século XIX 1815-1914. São Paulo: CULTRIX, 1981, $2^{\text {a }}$ ed. RODRIGUES, José Albertino (org.). Pareto: sociologia. São Paulo: Ática, 1984. SAES, Décio. A Formação do Estado Burguês no Brasil: 1888-1891. Rio de Janeiro: Paz e Terra, 1985. $2^{\text {a }}$ ed.

Classe Média e Política na Primeira República Brasileira (18891930). Petrópolis: Vozes, 1975.

Classe média e sistema político no Brasil. São Paulo: T. A. Queiroz, 1984.

SALES, Manuel Ferraz de Campos. Da Propaganda à Presidência. Brasília: Editora Universidade de Brasília, 1983.

SALLUM JÚNIOR, Brasilio. Capitalismo e cafeicultura: Oeste paulista, 18881930. São Paulo: Duas Cidades, 1982.

SANTOS, José Maria dos. Bernardino de Campos e o Partido Republicano Paulista. Rio de Janeiro: José Olympio, 1960.

A Política Geral do Brasil. Belo Horizonte: Itatiaia/São Paulo: Editora Universidade de São Paulo, 1989.

SCHULZ, John. O Exército na Política: Origens da Intervenção Militar, 18501894. São Paulo: EDUSP, 1994. 
O Exército e o Império in HOLANDA, Sérgio Buarque de, História Geral da Civilização Brasileira. Tomo II: O Brasil Monárquico. $4^{\circ}$ Volume: Declínio e Queda do Império. São Paulo: DIFEL, 1974, $2^{\text {a }}$ ed.

SILVA, Cyro. Floriano Peixoto - o Consolidador da República. São Paulo: Edaglit, 1963.

SILVA, Hélio. 1889: A República não Esperou o Amanhecer. Rio de Janeiro: Civilização Brasileira, 1972.

SKIDMORE, Thomas. Preto no branco: raça e nacionalidade no pensamento brasileiro. Rio de Janeiro: Paz e Terra, 1989, 2ª ed.

SODRÉ, Nelson Werneck. História Militar do Brasil. Rio de Janeiro: Civilização Brasileira, 1965, $2^{\mathrm{a}}$ ed.

TARGA, Luiz Roberto. Le Rio Grande do Sul e la création de I' État "développementiste" brésilien. Thèse pour le doctorat em sciences économiques, Université Pierre Mendes France, s/d.

TAVARES, Luís Henrique Dias (org.). Idéias Políticas de Manuel Vitorino. Brasília: Senado Federal / Rio de Janeiro: Fundação Casa de Rui Barbosa-MEC, 1981.

WITTER, José Sebastião. República, Política e Partido. Bauru-SP: EDUSC, 1999.

VÉLEZ Rodríguez, Ricardo. Castilhismo: uma filosofia da República. Brasília: Senado Federal, 2000.

VILLA, Marco Antônio. Canudos: o campo em chamas. São Paulo: Brasiliense, 1992.

Canudos: O povo da terra. São Paulo: Ática, 1999. 
